\title{
1990 Annual Report on Alaska's Mineral Resources
}

\section{U.S. GEOLOGICAL SURVEY CIRCULAR 1056}

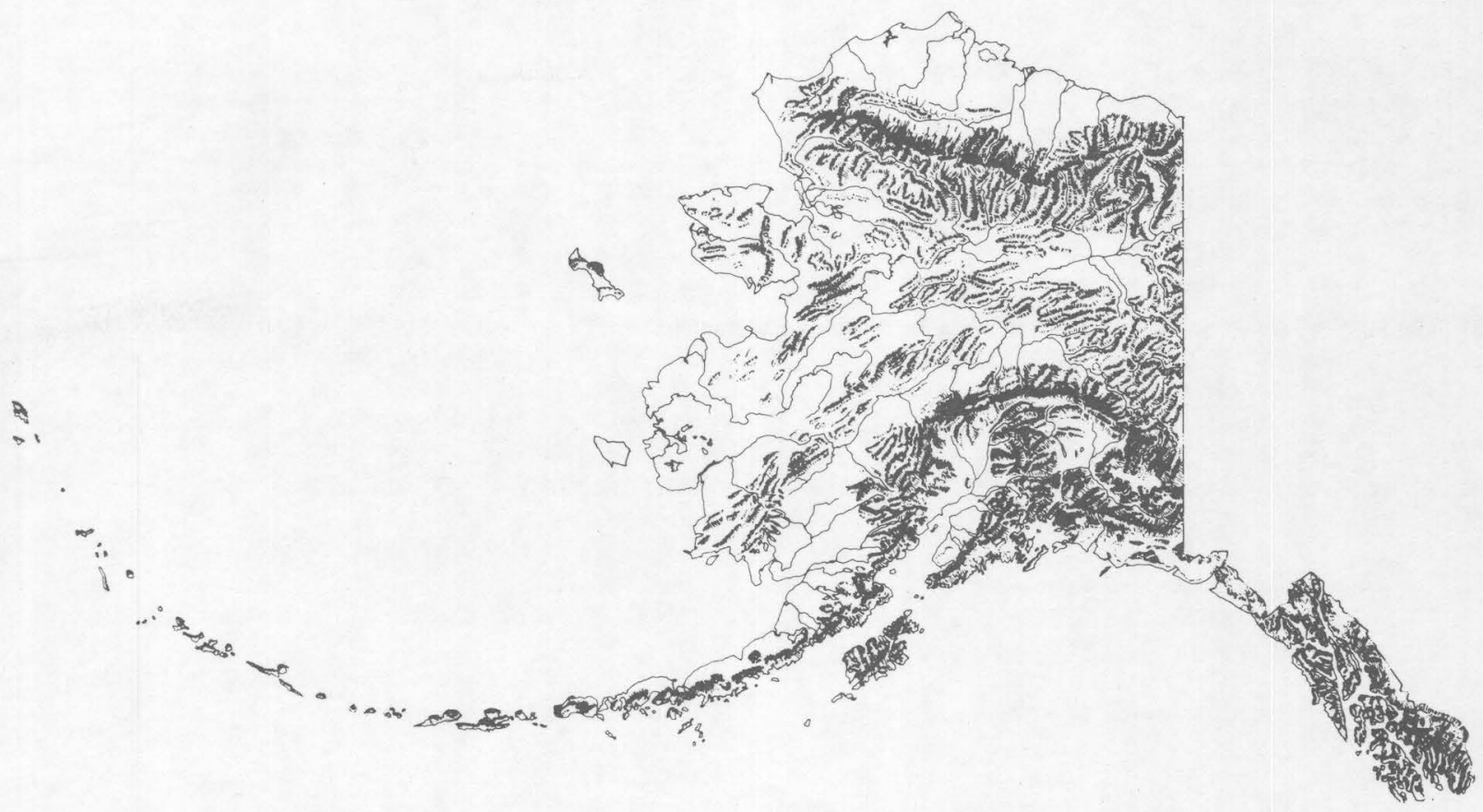

Prepared in cooperation with the Bureau of Land Management, the Fish and Wildlife Service, the Minerals Management Service, the National Park Service, the U.S. Bureau of Mines, the U.S. Forest Service, and the Department of Energy, as mandated by Section 1011 of the Alaska National Interest Lands Conservation Act, Public Law 96-487, of December 2, 1980

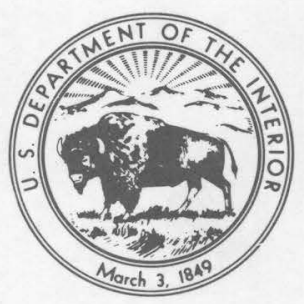




\section{AVAILABILITY OF BOOKS AND MAPS OF THE U.S. GEOLOGICAL SURVEY}

Instructions on ordering publications of the U.S. Geological Survey, along with prices of the last offerings, are given in the current-year issues of the monthly catalog "New Publications of the U.S. Geological Survey." Prices of available U.S. Geological Survey publications released prior to the current year are listed in the most recent annual "Price and Availability List." Publications that are listed in various U.S. Geological Survey catalogs (see back inside cover) but not listed in the most recent annual "Price and Availability List" are no longer available.

Prices of reports released to the open files are given in the listing "U.S. Geological Survey Open-File Reports," updated monthly, which is for sale in microfiche from the U.S. Geological Survey, Books and Open-File Reports Section, Federal Center, Box 25425, Denver, CO 80225. Reports released through the NTIS may be obtained by writing to the National Technical Information Service, U.S. Department of Commerce, Springfield, VA 22161; please include NTIS report number with inquiry.

Order U.S. Geological Survey publications by mail or over the counter from the offices given below.

\section{BY MAIL}

\section{Books}

Professional Papers, Bulletins, Water-Supply Papers, Techniques of Water-Resources Investigations, Circulars, publications of general interest (such as leaflets, pamphlets, booklets), single copies of Earthquakes \& Volcanoes, Preliminary Determination of Epicenters, and some miscellaneous reports, including some of the foregoing series that have gone out of print at the Superintendent of Documents, are obtainable by mail from

\section{U.S. Geological Survey, Books and Open-File Reports Federal Center, Box 25425 Denver, CO 80225}

Subscriptions to periodicals (Earthquakes \& Volcanoes and Preliminary Determination of Epicenters) can be obtained ONLY from the

\section{Superintendent of Documents \\ Government Printing Office \\ Washington, D.C. 20402}

(Check or money order must be payable to Superintendent of Documents.)

\section{Maps}

For maps, address mail orders to

\section{U.S. Geological Survey, Map Distribution \\ Federal Center, Box 25286 \\ Denver, CO 80225}

Residents of Alaska may order maps from

\author{
Alaska Distribution Section, U.S. Geological Survey, \\ New Federal Bullding - Box 12 \\ 101 Twelfth Ave., Fairbanks, AK 99701
}

\section{OVER THE COUNTER}

\section{Books}

Books of the U.S. Geological Survey are available over the counter at the following Geological Survey Public Inquiries Offices, all of which are authorized agents of the Superintendent of Documents:

- WASHINGTON, D.C.--Main Interior Bldg., 2600 corridor, 18th and C Sts., NW.

- DENVER, Colorado--Federal Bldg., Rm. 1691961 Stout St.

- LOS ANGELES, California--Federal Bldg., Rm. 7638, 300 N. Los Angeles St.

- MENLO PARK, Callfornia--Bldg. 3 (Stop 533), Rm. 3128, 345 Middlefield Rd.

- RESTON, Virginia--503 National Center, Rm. 1C402, 12201 Sunrise Valley Dr.

- SALT LAKE CITY, Utah--Federal Bldg., Rm. 8105, 125 South State St.

- SAN FRANCISCO, California--Customhouse, Rm. 504, 555 Battery St.

- SPOKANE, Washington--U.S. Courthouse, Rm. 678, West 920 Riverside Ave..

- ANCHORAGE, Alaska--Rm. 101, 4230 University Dr.

- ANCHORAGE, Alaska--Federal Bldg, Rm. E-146, 701 C St.

\section{Maps}

Maps may be purchased over the counter at the U.S. Geological Survey offices where books are sold (all addresses in above list) and at the following Geological Survey offices:

- ROLLA, Missouri--1400 Independence Rd.

- DENVER, Colorado--Map Distribution, Bldg. 810, Federal Center

- FAIRBANKS, Alaska--New Federal Bldg., 101 Twelfth Ave. 
1990 Annual Report on Alaska's Mineral Resources 


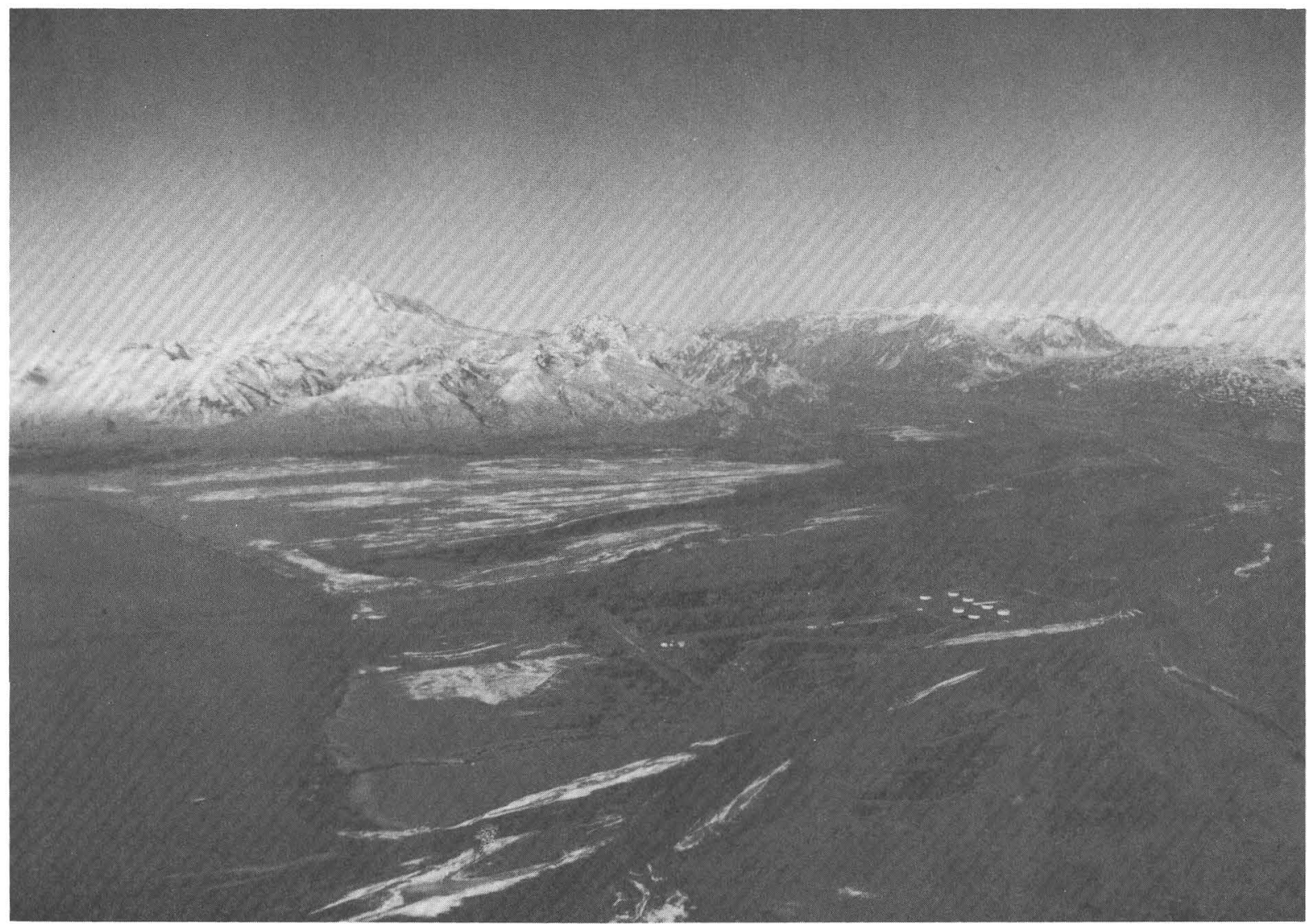

Frontispiece. Mount Redoubt volcano at left; Drift River oil terminal in right foreground. Photograph by R. McGimsey. 


\title{
1990 Annual Report on Alaska's Mineral Resources
}

\author{
JILL L. SCHNEIDER, Editor
}

Prepared in cooperation with the Bureau of Land Management, the Fish and Wildlife Service, the Minerals Management Service, the National Park Service, the U.S. Bureau of Mines, the U.S. Forest Service, and the Department of Energy, as mandated by Section 1011 of the Alaska National Interest Lands Conservation Act, Public Law 96-487, of December 2, 1980

A summary of mineral resource activities in Alaska for the year 1989 


\section{U.S. DEPARTMENT OF THE INTERIOR}

MANUEL LUJAN, JR., Secretary

U.S. GEOLOGICAL SURVEY

Dallas L. Peck, Director

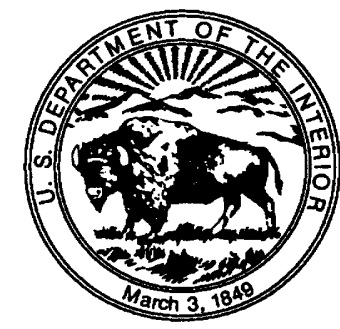

Any use of trade, product, or firm names

in this publication is for descriptive

purposes only and does not constitute

endorsement by the U.S. Government

Free on application to the

Books and Open-File Reports Section

U.S. Geological Survey

Federal Center, Box 25425

Denver, CO 80225 


\section{CONTENTS}

$\begin{array}{rr}\text { Summary } & 1 \\ \text { Energy resources } & 1 \\ \text { Oil and gas } & 1\end{array}$

Arctic National Wildlife Refuge

Exxon Valdez oil spill

2

Coal and peat 2

Uranium 3

Geothermal resources 3

Nonfuel-mineral resources 3

Metallic minerals 3

Industrial minerals 4

Introduction 4

Mineral programs 4

Department of the Interior 4

U.S. Geological Survey 4

U.S. Bureau of Mines 7

Minerals Management Service 8

Bureau of Land Management

Fish and Wildlife Service

National Park Service 10

Department of Agriculture 10

U.S. Forest Service 10

Department of Energy 10

Contacts for further information 10

Energy resources 11

Oil and gas resources 11

Overview of production and prices

Exploration

13

Production activity

North Slope 14

Cook Inlet 15

State activity and lease sales 16

Transportation 16

Activity by Federal agencies 18

Minerals Management Service

18

Leasing activity 18

Lease status and exploration 18

Future sales 19

National resource assessment 20

Joint State-Federal studies

20

U.S. Geological Survey 20

North Slope 20

Interior basins 22

Cook Inlet 22

Gas hydrates 22

Thermal maturity map of Alaska 22

National resource assessment 22

Bureau of Land Management 24

Fish and Wildlife Service 24

Kenai National Wildlife Refuge 24

Activities under Section 1008 of ANILCA 26

Resource activity impact assessment 26 


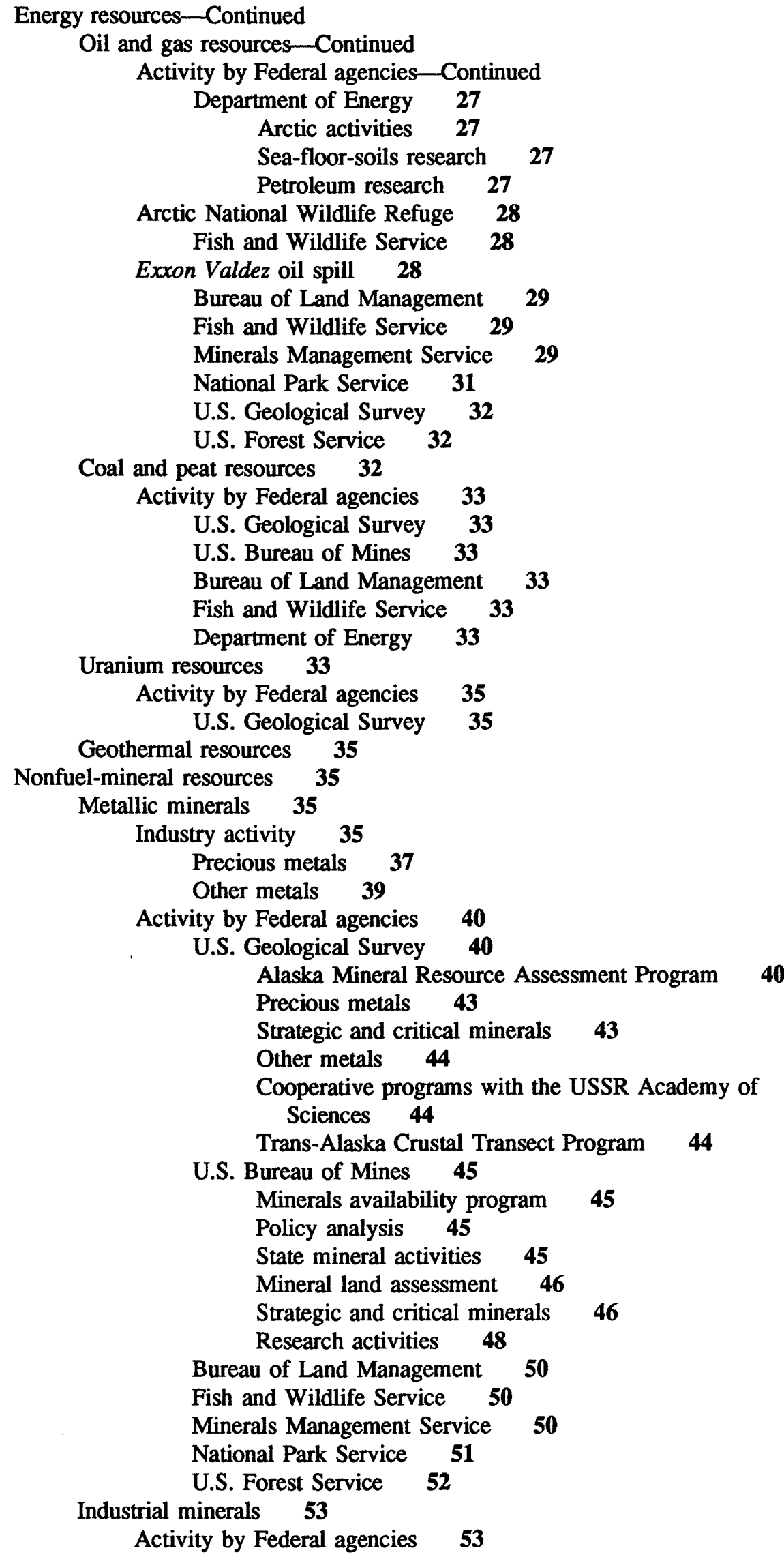


Nonfuel-mineral resources-Continued

Industrial minerals-Continued

Activity by Federal agencies-Continued

U.S. Bureau of Mines 53

Bureau of Land Management

Fish and Wildlife Service 53

References cited

U.S. Forest Service 53

Appendix 1. Alaska mineral reports released during 1989 and early 1990

Department of the Interior 56

U.S. Geological Survey 56

U.S. Bureau of Mines $\mathbf{5 9}$

Minerals Management Service 60

Bureau of Land Management 61

Fish and Wildlife Service 61

National Park Service 61

Department of Energy 61

Non-Federal reports 62

Alaska Division of Geological and Geophysical Surveys 62

Additional non-Federal publications 63

Appendix 2. Roles of Federal agencies in mineral programs 64

Department of the Interior 64

U.S. Geological Survey 64

U.S. Bureau of Mines 64

Minerals Management Service 65

Bureau of Land Management 66

Fish and Wildlife Service 66

National Park Service 66

Department of Agriculture 66

U.S. Forest Service 66

Department of Energy 67

\section{FIGURES}

Frontispiece. Photograph of Mount Redoubt volcano and Drift River oil terminal.

1. Map of Federal land ownership in Alaska (boundaries as of June 1987) 5

2. Photograph of complexly deformed rocks in Seldovia quadrangle, site of USGS level III AMRAP studies 6

3. Photograph of USBM geologists using helicopter-portable auger to sample placer tin and rare-earth-element deposits in central Alaska 7

4. Map showing national wildlife refuges in Alaska 9

5. Map showing locations of exploratory oil wells, oil and gas fields, and possible petroleum-bearing onshore sedimentary basins 12

6. Graph of annual average United States oil production and worldwide price of oil for 1979-1989 13

7. Photograph of Drift River oil terminal and debris flow from Mount Redoubt volcano 15

8-11. Maps showing:

8. Areas of oil and gas lease sales 17

9. Offshore geologic province boundaries as defined by MMS and USGS for national assessment, and location of joint MMS-State studies 21

10. Thermal maturity data coverage for Alaska 
11. Onshore Favorable Petroleum Geological Provinces and locations of DOE-funded research in 1989 25

12. Photograph of drill rig at Prudhoe Bay on Alaska's North Slope 26

13. Map showing location of $T / V$ Exxon Valdez grounding on Bligh Reef in Prince William Sound and trajectory of resultant oil spill 30

14. Photograph of oil spill cleanup, Prince William Sound 31

15-18. Maps showing:

15. Areas of potential coal and peat, uranium, and geothermal resources 34

16. Areas of significant industry activity involving metallic minerals (excluding uranium) in 1989, and mine and deposit locations 38

17. Status of USGS level III AMRAP quadrangle studies as of January $1990 \quad 41$

18. Locations of USGS level IV AMRAP metallic-mineral studies in 198942

19. Photograph of placer gold nugget from interior Alaska 44

20. Map showing locations of USBM mineral studies in $1989 \quad 47$

21. Photograph of ADGGS geologist examining chromite deposit in western

Brooks Range, northwestern Alaska

49

\section{TABLES}

1. Fluctuation in price of Alaska North Slope crude oil

2. Alaska exploratory oil wells drilled in $1989 \quad 14$

3. State of Alaska oil and gas lease sales, $1989 \quad 16$

4. Alaska OCS leases and wells drilled, 1976-1989 18

5. Proceeds from lease sales in Alaska OCS planning areas 19

6. Reports summarizing petroleum geology and geologic plays in Alaska from the January 1, 1987, national resource assessment

7. Mining production in Alaska, 1986-1989 36

8. Level IV studies of the USGS Alaska Mineral Resource Assessment Program and related studies active in $1989 \quad 43$

9. Areas of U.S. Bureau of Mines activity in mining districts and at strategic and critical mineral localities in 1989 


\section{ACRONYMS AND ABBREVIATIONS}

$\begin{array}{ll}\text { ADGGS } & \text { Alaska Division of Geological and Geophysical Surveys } \\ \text { ADNR } & \text { Alaska Department of Natural Resources } \\ \text { AFOC } & \text { Alaska Field Operations Center } \\ \text { A-J } & \text { Alaska-Juneau mine } \\ \text { AML } & \text { Abandoned Mineral Lands } \\ \text { AMRAP } & \text { Alaska Mineral Resource Assessment Program } \\ \text { ANGTS } & \text { Alaska Natural Gas Transportation System } \\ \text { ANILCA } & \text { Alaska National Interest Lands Conservation Act } \\ \text { ANWR } & \text { Arctic National Wildlife Refuge } \\ \text { AORIS } & \text { Arctic and Offshore Research Information System } \\ \text { ATTO } & \text { Alaska Technology Transfer Office } \\ \text { BLM } & \text { Bureau of Land Management } \\ \text { B/MIS } & \text { Bibliographic/Management Information System } \\ \text { CAMA } & \text { Central Arctic Management Area } \\ \text { CRREL } & \text { Cold Regions Research and Engineering Laboratory } \\ \text { DOE } & \text { Department of Energy } \\ \text { DOI } & \text { Department of the Interior } \\ \text { DST } & \text { Deep stratigraphic test } \\ \text { EEZ } & \text { Exclusive Economic Zone } \\ \text { EIS } & \text { Environmental Impact Statement } \\ \text { EPA } & \text { Environmental Protection Agency } \\ \text { FEIS } & \text { Final Environmental Impact Statement } \\ \text { FWS } & \text { Fish and Wildlife Service } \\ \text { GIS } & \text { Geographic Information Systems } \\ \text { MAS } & \text { Minerals Availability System } \\ \text { MILS } & \text { Minerals Industry Location System } \\ \text { MMS } & \text { Minerals Management Service } \\ \text { MRDS } & \text { Mineral Resources Data System } \\ \text { NEPA } & \text { National Environmental Policy Act } \\ \text { NOAA } & \text { National Oceanographic and Atmospheric Administration } \\ \text { NPRA } & \text { National Petroleum Reserve in Alaska } \\ \text { NPS } & \text { National Park Service } \\ \text { NTIS } & \text { National Technical Information Service } \\ \text { OCS } & \text { Outer Continental Shelf } \\ \text { PCB } & \text { Polychlorinated biphenyl } \\ \text { PGM } & \text { Platinum-group metal } \\ \text { REE } & \text { Rare-earth element } \\ \text { SCLDF } & \text { Sierra Club Legal Defense Fund } \\ \text { SEMS } & \text { Seafloor Earthquake Measurement System } \\ \text { SLRC } & \text { Salt Lake City Research Center } \\ \text { TACT } & \text { Trans-Alaska Crustal Transect } \\ \text { TAGS } & \text { Trans-Alaska Gas System } \\ \text { TALI } & \text { Trans-Alaska Lithosphere Investigation } \\ \text { TAPS } & \text { Trans-Alaska Pipeline System } \\ \text { USBM } & \text { U.S. Bureau of Mines } \\ \text { USCG } & \text { U.S. Coast Guard } \\ \text { USFS } & \text { U.S. Forest Service } \\ \text { USGS } & \text { U.S. Geological Survey } \\ \text { YPC } & \text { Yukon Pacific Corporation } \\ & \end{array}$




\title{
CONTRIBUTORS
}

\section{DEPARTMENT OF THE INTERIOR}

\author{
Bureau of Land Management \\ Gary Brougham \\ Joseph Dygas \\ Linn Gum \\ Mike Menge \\ Tom Mowatt
}

Fish and Wildlife Service

Mary Lynn Nation

Ann Rappoport

Robert Richey

Robert Seemel

Robyn Thorson

\section{Minerals Management Service}

Donald Olson

National Park Service

Alex Carter

Gene Griffin

Lynn Griffiths

Russell Kucinski

Floyd Sharrock

U.S. Bureau of Mines

Steven Fechner

U.S. Geological Survey

Kendell Dickinson

David Howell

Thomas Light

Jill Schneider

Gary Stricker

DEPARTMENT OF AGRICULTURE

U.S. Forest Service

Roger Griffin

\section{DEPARTMENT OF ENERGY}

Bill Gwilliam

Rod Malone

Harold Shoemaker 


\title{
1990 Annual Report on Alaska's Mineral Resources
}

\author{
Jill L. Schneider, Editor
}

\section{SUMMARY}

Section 1011 of the Alaska National Interest Lands Conservation Act (ANILCA) of 1980 requires that "On or before October 1, 1982, and annually thereafter, the President shall transmit to Congress all pertinent public information relating to minerals in Alaska gathered by the United States Geological Survey, Bureau of Mines, and any other Federal agency." This report has been prepared in response to that requirement.

This circular is the ninth in a series of annual ANILCA reports. The report provides information about current Alaskan mineral projects and events during 1989; the emphasis is on Federal activity. The report addresses both onshore and offshore areas of Alaska.

The U.S. Geological Survey (USGS), the U.S. Bureau of Mines (USBM), and the Minerals Management Service (MMS) are the principal Federal agencies that publish information about energy and mineral resources in Alaska. Their reports and data form the basis for decisions by other Federal agencies regarding land use, access, environmental impacts, and mining claim evaluation. The time required for sample analysis, data synthesis, and publication is lengthy, so the scientific reports are generally issued a year or more after initial sample and data collection. Other sources of information for this report include additional Federal and State publications, trade and professional journals, newspaper articles, presentations at public meetings and hearings, and press releases.

Information is provided for two broad categories of minerals: energy resources and nonfuel-mineral resources.

\section{Energy Resources}

\section{Oil and Gas}

Oil and gas remained the most valuable mineral resource commodities in Alaska for 1989. Total production of oil and natural gas liquids decreased 7.5 percent to 702

Manuscript approved for publication, September 14, 1990. million barrels, and dry natural gas production increased 3.7 percent to 195 billion cubic feet. Daily oil production averaged 1.9 million barrels, about 25 percent of the Nation's total. The average oil price for the year was just under \$17 per barrel.

The Alaska Oil and Gas Conservation Commission issued 132 drilling permits in 1989; 15 exploratory wells and 130 development and service wells were active. A new oil field containing 300 million barrels of recoverable oil was discovered at Point McIntyre on the North Slope. Shell Western initiated the first wildcat drilling program in the Chukchi Sea. Seismic surveys were conducted in the Beaufort Sea, Chukchi Sea, lower Cook Inlet, Gulf of Alaska, Kenai Peninsula, Matanuska-Susitna Borough, and the North Slope. Yukon Pacific Corporation was granted a permit to export natural gas to Pacific Rim countries and is studying construction of the Trans-Alaska Gas System.

North Slope oil production peaked in 1988 and began to decline in 1989. Four major fields-Endicott, Kuparuk River, Milne Point, and Prudhoe Bay-produced 98 percent of the State's total oil; Milne Point was reactivated in April 1989 after three years of "warm shutdown." The Trans-Alaska Pipeline System currently carries 1.9 million barrels of North Slope oil daily, but extreme weather conditions and the Exxon Valdez oil spill caused several slowdowns in pipeline throughput during the year. In south-central Alaska, four of the Cook Inlet region's gas fields-Beluga, Kenai, McArthur River, and North Cook Inlet-produced 92 percent of the State's dry natural gas.

Two oil and gas lease sales were held by the State of Alaska in 1989, netting $\$ 2.1$ million in high bids for North Slope acreage. Two private oil and gas lease sales were also held for acreage in Cook Inlet and on the North Slope. Active Federal leasing in 1989 totaled 5,695 leases onshore and 930 leases on the Alaska Outer Continental Shelf (OCS). The State of Alaska received \$8.9 million from Federal minerals revenue, the bulk of which was derived from onshore oil and gas leases.

The results of the joint MMS-USGS national oil and gas inventory were published in 1989. Estimates for undiscovered conventional oil deposits in Alaska total 13.2 billion barrels (mean value). The MMS also worked with the Alaska Division of Geological and Geophysical Surveys 
(ADGGS) to model the thermal evolution of the Beaufort Sea continental margin.

The USGS continued research on Alaska's North Slope to evaluate the extent and mode of formation of methane-gas hydrates; additional studies include basin modeling, analysis of tectonic development, and documentation of petroleum systems. In interior and southern Alaska, work continues on the geology and petroleum potential of Late Cretaceous and Tertiary sedimentary basins. A statewide thermal maturity map for oil- and gas-related rocks is being compiled.

In 1989, the Bureau of Land Management (BLM) completed resource assessments in four central and southcentral Alaska planning areas and initiated an assessment in the Western Arctic planning area. In addition, BLM requested industry responses for interest in a lease sale in the National Petroleum Reserve in Alaska (NPRA). BLM geologists continued their ongoing minerals studies with special emphasis on the North Slope and nearshore Beaufort Sea.

In keeping with its mission to protect fish, wildlife, and habitat, the Fish and Wildlife Service (FWS) monitored petroleum-related activities and the cleanup of materials contaminated with polychlorinated biphenyls in the Kenai National Wildlife Refuge. The FWS issued special-use permits for geologic work in three refuges and reviewed 32 permit applications related to oil and gas activities for the U.S. Army Corps of Engineers in order to recommend measures to minimize habitat losses. Three Federal OCS environmental impact statements (EIS's) were reviewed.

The Department of Energy (DOE) continued to develop the computerized data base of Arctic energy-related technical information. DOE also sponsored seminars presenting new technological petroleum research findings, coordinated interagency petroleum research, and studied the applicability of recovery techniques to petroleum reservoirs in the Arctic. Research focused on ice-island generation and drift paths in the Beaufort Sea, responses of sea-floor soils to strong earthquakes, gas-hydrate reservoirs, and recovery of deep-source gas.

\section{Arctic National Wildlife Refuge}

During 1989, the FWS and BLM reviewed and updated management plans to carry out an orderly oil and gas leasing program for the 1002 area of the Arctic National Wildlife Refuge (ANWR), should Congress ever authorize such a program. A legislative EIS was issued December 16, 1988 , on the issue of Native land exchanges between ANWR and other refuges in Alaska. The proposed exchanges were recommended by the Secretary of the Interior in a Record of Decision signed in January 1989.

The BLM and FWS continued to respond to public and Congressional inquiries regarding oil and gas potential of the 1002 area and potential impacts to fish and wildlife. To better address these questions, BLM scientists continue to supplement their ANWR studies by reviewing all pertinent geologic and geophysical information. The FWS is continuing a biological studies program in the area.

\section{Exxon Valdez Oil Spill}

More than 11 million gallons of crude oil was released into Prince William Sound when the oil tanker T/V Exxon Valdez ran aground on Bligh Reef on March 24, 1989. Containment efforts failed to halt the spread of oil over 3,000 miles of Alaskan coastline. Exxon Corporation spent over $\$ 1$ billion in cleanup and resource protection efforts in 1989 and will continue its cleanup activities in the summer of 1990. The BLM and National Park Service (NPS) established multi-agency coordination groups to serve as clearinghouses for spill-related concerns. The BLM also conducted a review of cleanup materials in-place along the pipeline, provided staffing assistance to handle public inquiries, erected four remote weather stations, and provided transport, supplies, and equipment for the cleanup effort. The FWS documented the spill's effects on wildlife, established wildlife rescue centers, and monitored shoreline cleanup activities. The MMS provided funds for both cleanup staff and assessment studies. The NPS issued special-use permits for activities within national park boundaries, conducted surveys to locate and prioritize treatment areas, supervised cleanup activities, and provided personnel and logistical support to FWS and other groups. The USGS analyzed bottom sediments in Prince William Sound for oil pollution. The U.S. Forest Service (USFS) coordinated logistical sitings and worked to prevent the destruction of wildlife nurseries and archaeological sites.

\section{Coal and Peat}

Although production dipped slightly in 1989, coal was the third most valuable mineral commodity in Alaska; 1.45 million tons was produced at an estimated worth of $\$ 41.5$ million. Fifty percent of this total was exported to South Korea.

All of Alaska's commercial coal is produced from a single mine in central Alaska by the Usibelli Coal Company. A second mine is being developed by Idemitsu Kosan at Wishbone Hill in the Matanuska Valley. State funds will be used to upgrade the road from the Idemitsu mine to the Palmer railyard.

The USGS continued its coal program with an assessment of the coal resources in the Seldovia quadrangle. Other research involved geochemical studies of coal samples from the Healy coal fields and from the North Slope.

Other Federal coal activity in 1989 included USBMsponsored studies for revegetating abandoned coal mine properties, BLM management of a coal lease in the Jarvis Creek field near Delta Junction, and comments by the FWS regarding mine development plans at the Wishbone Hill 
site. The Department of Energy (DOE) awarded a $\$ 93.2$ million Clean Coal Technology grant for the construction of a new power plant at the Usibelli coal mine at Healy.

Alaska's peat production fell 7 percent in 1989 to 51,000 cubic yards, valued at $\$ 352,000$. Peat is used primarily as an agricultural soil conditioner; minor amounts are burned for heat in some villages.

\section{Uranium}

The last uranium mined in Alaska was produced at Bokan Mountain in southeastern Alaska in 1971. High costs of exploration and development coupled with low market value have prevented the exploitation of other uranium resources in the State.

Exploration research for uranium was continued by the USGS at a low level; most of the activity relates to previously collected data. Three reports were issued describing a thorium-uranium deposit near Mount Prindle in the Livengood quadrangle.

\section{Geothermal Resources}

Geothermal resources in Alaska are associated with widespread young volcanic activity in the south-central part of the State. Battle Mountain Exploration is investigating the practicality of developing a geothermal production facility at Makushin Volcano in the Aleutian Islands. No Federal research was funded for geothermal studies in 1989.

\section{Nonfuel-Mineral Resources}

\section{Metallic Minerals}

During 1989, Alaska's mineral industry experienced positive growth in the production and exploration sectors but suffered a major decline in development expenditures. Total mineral production values increased 19 percent to $\$ 277$ million. Exploration costs rose slightly to $\$ 47.8$ million, a 5-percent increase over 1988 . The decline in development expenditures from \$274.9 million in 1988 to $\$ 134.3$ million in 1989 reflects the shift from development to production modes at both the Greens Creek and Red Dog projects.

Metals production ballooned 52 percent in 1989 to $\$ 173.8$ million; much of this increase was due to inaugural lead-zinc-silver production at the Greens Creek mine in southeastern Alaska. Gold remained the second most valuable mineral commodity in the State, after oil and gas; 284,617 ounces was produced at a value of $\$ 108.7$ million.

In the exploration for precious metals, industry activity again focused on lode gold. Exploration drilling continued at the Fort Knox deposit near Fairbanks, at the Shumagin prospect on Unga Island on the Alaska Peninsula, and at the Rock Creek prospect near Nome on the Seward Peninsula. Further exploration and development work were completed at the Kensington and Jualin mines north of Juneau. Development drilling and mine-plan evaluation were conducted on the Alaska-Juneau mine near Juneau. In addition, the State held a lottery for 19 placer-gold leases offshore from Nome.

Industry activity also included the continued successful development of the Red Dog zinc-lead-silver deposit in northwestern Alaska, the opening of the Greens Creek silver-zinc-gold-lead mine on Admiralty Island in southeastern Alaska, and continued studies at the Quartz Hill molybdenum deposit in southeastem Alaska. When peak production is attained, the Greens Creek deposit will be the largest silver producer in the United States, and the Red Dog deposit will be the largest zinc-lead producer in the Western world.

The Alaska Mineral Resource Assessment Program (AMRAP) continues to be the focus of USGS mapping and mineral assessment in Alaska. In 1989, USGS scientists released numerous reports on geologic mapping, mineral resource assessment, and specialized geologic studies of Alaska lands; initiated and continued research, field studies, and report-writing for mineral assessments of $261: 250,000$ scale quadrangles; and performed specialized geologic studies at a detailed scale for 36 projects around the State.

Site-specific studies were conducted on preciousmetal deposits and strategic and critical mineral deposits. A team of USGS geologists visited the Soviet Far East as part of the comparative study of lode mineral deposits there and in Alaska. Work on the USGS Trans-Alaska Crustal Transect (TACT) program in 1989 included (1) detailed geologic mapping, (2) magnetotelluric, seismic-refraction, and seismic-reflection surveys, and (3) interpretation, publication, and presentations of project findings.

The USBM examined the impact of environmental constraints on mining in Alaska, summarized the availability of Alaska land for mineral exploration, performed an economic analysis of 171 mineral deposits in the Tongass National Forest, and collected data on the use of cyanide in Alaska's mining industry. A computerized inventory of claim owners in the State of Alaska through 1988 was developed. Mineral assessment programs were carried out in the Ketchikan and Valdez Creek mining districts. The assessment of the Juneau mining district was completed. Geologists also evaluated strategic and critical mineral deposits at 21 locations in the State.

The USBM's two new research projects in the State are designed to study deep-placer mining technology and mine closure in arctic and subarctic climates; ongoing research includes beneficiation studies of Alaskan critical and strategic ores. The USBM Mineral Institute program provides funding for both the University of Alaska and the University of Mississippi Marine Minerals Technology Center. The USBM also co-funds the Cold Regions Research and Engineering Laboratory (CRREL) permafrost tunnel research facility near Fox and operates the Alaska Technology Transfer Office (ATTO) in Anchorage. 
The BLM issued four final EIS's and their respective Records of Decision analyzing the impacts of placer mining on four watersheds in interior Alaska. One mineral patent was issued, and 247 mining operations were active on BLM-administered lands. The FWS monitored for contaminants in the drainages below inactive and active mines at 10 locations and identified environmental concerns at 7 other mining locations in the State. The MMS is planning a competitive OCS minerals lease sale of gold-bearing placers in Norton Sound south of Nome.

The NPS reviewed mining plans of operations, conducted claim validity examinations, and inventoried natural and cultural resources on mining claims within park boundaries. Reclamation of land disturbed by past mining continued on 27 acres of abandoned claims in Denali National Park and Preserve. Other ongoing projects include inventories of abandoned mineral lands, preparation of topographic maps of mining claim areas, and the use of GIS (geographic information systems) computer software to analyze engineering and environmental data when evaluating the environmental effects of mineral development. Draft final EIS's were completed for Denali and WrangellSt. Elias National Parks and Preserves and Yukon-Charley Rivers National Preserve; acquisition of all patented and unpatented mining claims in the three units is recommended.

The USFS conducted mineral validity examinations on mining claims in national forests. Work continued on the revision of the Tongass National Forest land management plan.

\section{Industrial Minerals}

The use of nonmetallic nonfuel resources in Alaska slumped 16 percent in 1989 due to a decrease in the number of construction projects in the State. Sand and gravel combined was the fourth-ranked mineral commodity at $\$ 39.9$ million; building stone production totaled $\$ 20.3$ million. The export of glacial ice to Japan continues to escalate.

The USBM evaluated the industrial minerals of the Valdez Creek mining district. The BLM made 10 sales for 8,220 cubic yards total of mineral materials. The FWS continued permitting and monitoring small ongoing sand and gravel operations in support of local transportation and industry in various areas of the state. The USFS sold sand, gravel, and quarried stone for use in the construction of timber sale roads, breakwaters, and airports.

\section{INTRODUCTION}

Section 1011 of the Alaska National Interest Lands Conservation Act (ANILCA) of 1980 requires that "On or before October 1, 1982, and annually thereafter, the President shall transmit to Congress all pertinent public information relating to minerals in Alaska gathered by the United
States Geological Survey, Bureau of Mines, and any other Federal agency." The USGS subsequently was delegated as the lead agency in responding to this requirement. This circular, the ninth in its series, synthesizes information made public in 1989.

The USGS and the USBM are the principal Federal agencies that generate information about onshore mineral resources in Alaska; the MMS is the prime agency reporting on resource activities in Alaska's coastal waters. Their data, analyses, and reports are used by other agencies in decisionmaking on land use, access, environmental impacts, and mining claim evaluation.

As used herein, the term "public information" includes results of Federal projects as published in Government reports and professional and trade journals; talks by representatives of Federal and State agencies and industry at sym-posia, conferences, and other public forums; and proceedings volumes, press releases, and newspaper articles. Unless otherwise indicated, references cited are listed at the end of this report; appendix 1 lists additional mineral reports published or released in 1989. Data from the ADGGS annual report on Alaska's mineral industry are used in parts of this circular.

This report focuses on energy resources (oil, gas, coal, peat, uranium, and geothermal) and nonfuel-mineral resources (metallic and industrial minerals).

The next section describes the current mineral programs of land-management and other Federal agencies in Alaska. The roles of these agencies as they relate to minerals are discussed in appendix 2. The distribution of lands under Federal management is shown in figure 1.

\section{MINERAL PROGRAMS}

\section{Department of the Interior}

\section{U.S. Geological Survey}

As directed by Section 1010 of ANILCA, the Secretary of the Interior requires an assessment of "the oil, gas, and other mineral potential on all public lands in the State of Alaska in order to expand the data base with respect to the mineral potential of such lands." AMRAP is one of the major responses of the USGS to this legislation. The goal of this program is a systematic investigation of the State's mineral resources through four progressively more detailed levels of study. Geologic studies at levels I and II are general and cover large areas. Studies at level III draw on many geologic disciplines to produce resource assessments at scales of 1:250,000 and 1:125,000. Level IV research focuses on detailed studies of specific mining districts, mineral deposits, or topics related to the genesis of mineral deposits. In 1989 , level III studies were under way in 26 quadrangles (fig. 2), and a total of 36 level IV studies were in progress. 


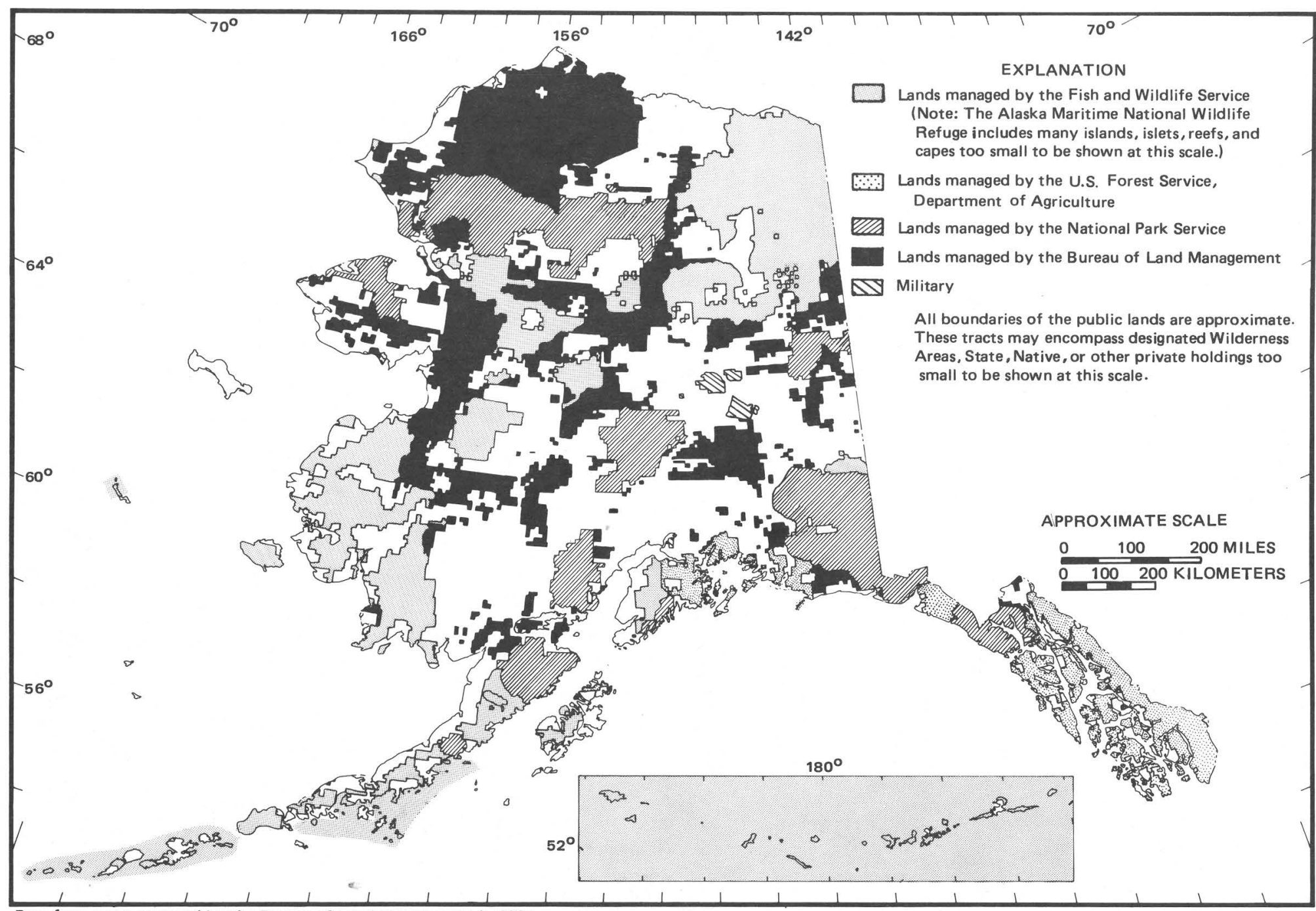

Base from maps prepared by the Bureau of Land Management in 1987.

Figure 1. Federal land ownership in Alaska (boundaries as of June 1987). 
USGS AMRAP publications are a key source of information about Alaska's economic geology. AMRAP studies are essential for the determination of the distribution and potential of national mineral and energy endowments, for the formulation of public policy affecting resource and land management, and for the improvement of resource assessment technology in minimizing potential impacts from development. These studies are also vital to industry for the location of new mineral deposits by developing concepts, models, and techniques to identify such deposits.

The USGS performs its work in Alaska through several programs in addition to AMRAP. Among the programs active in 1989 were (1) studies of mineral resources on public lands, (2) the Development of Assessment Techniques Program, whose goal is to improve the ability to identify and evaluate mineral resources, (3) the Strategic and Critical Minerals Program, for identifying the potential of these resources to meet national military and economic needs, (4) the Oil and Gas Investigations Program, which focuses on studies of petroleum-forming processes and prospective regions in order to produce reliable estimates of undiscovered petroleum resources, and (5) the Geothermal Investigations Program, which focuses on studies of the nature, distribution, and energy potential of these resources nationally. The mineral-related aspects of many of these programs are more fully described in later sections of this report.

Other USGS programs that are not mineral-specific include (1) the Earthquake Hazards Reduction Program, which seeks to mitigate earthquake losses through providing data and evaluations for land-use planning, engineering, and emergency preparations, (2) the Volcano Hazards Program, which includes studies on the assessment, reduction, and prediction of volcanic hazards, and (3) the Geologic Framework Program, involving both general and specialized research on the regional geology of Alaska. In addition, the Trans-Alaska Crustal Transect (TACT) program is a multidisciplinary approach to study the Earth's crust along a corridor from the Pacific Ocean to the Arctic Ocean. This program is coordinated with the Trans-Alaska Lithosphere Investigation (TALI), which utilizes earth scientists from the ADGGS, the University of Alaska, other universities, and private industry.

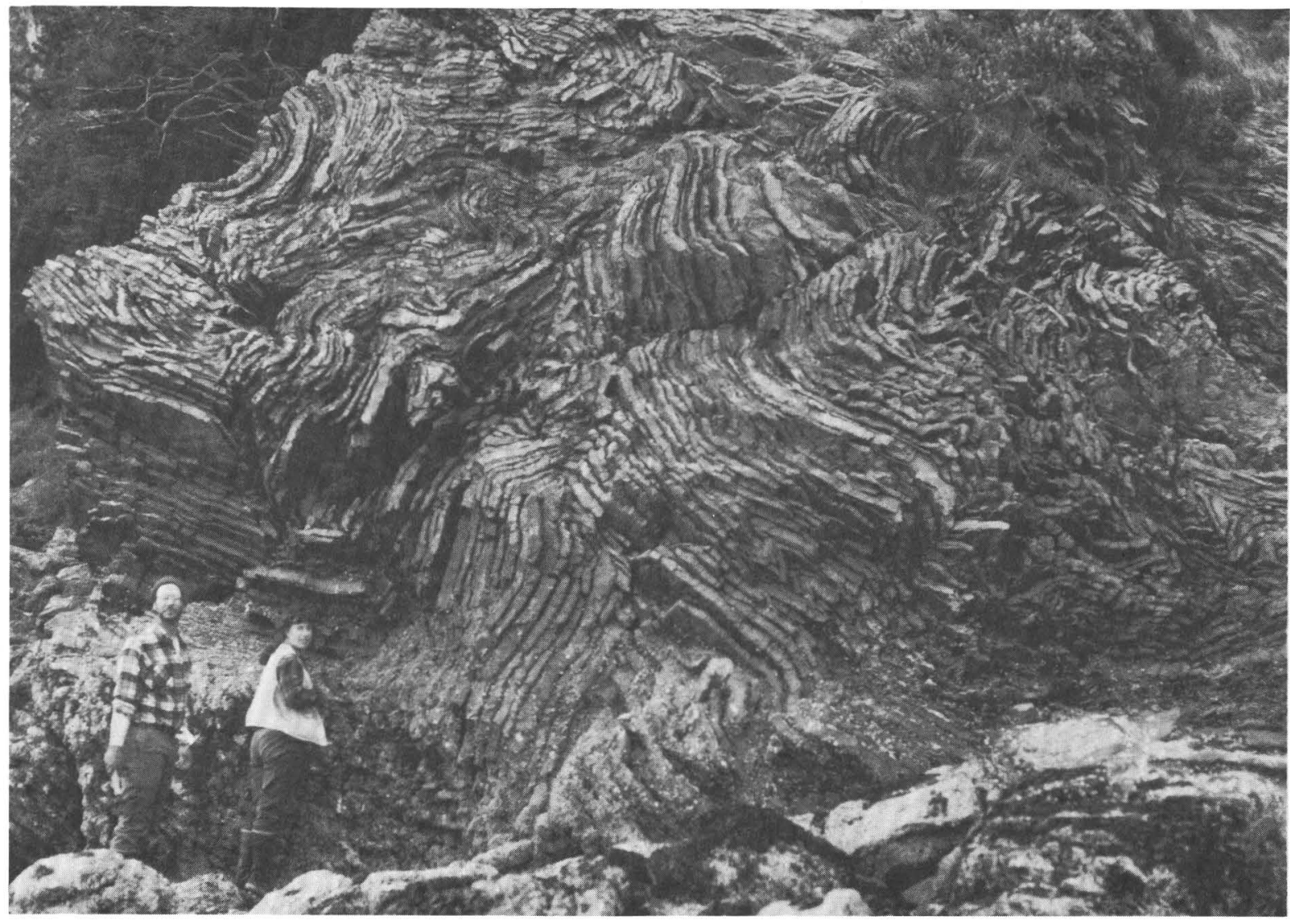

Figure 2. Complexly deformed cherts of the McHugh Complex in Seldovia quadrangle, site of USCS level III AMRAP studies. Photograph by D. Bradley. 
Economic-geologic information for mineral occurrences in the United States and worldwide is available through the USGS Mineral Resources Data System (MRDS) computerized files. In Alaska, records focusing on metallic minerals contain 2,051 entries for forty 1:250,000-scale quadrangles in the south-central and southeastern areas of the State. Data in these files include mineral-deposit size, type, description, location, reserves, and pertinent literature references for known or potentially locatable mineral resources (Leonard and Huber, 1987). Geologic information from the Alaska MRDS files can be used to complement economically oriented data from the Mineral Availability and Mineral Industry Location Systems computerized files of the USBM, discussed in the next section. Further MRDS information can be obtained from Donald F. Huber, Central and Western Regional Representative, U.S. Geological Survey, MS 984, 345 Middlefield Road, Menlo Park, CA 94025.

\section{U.S. Bureau of Mines}

During 1989, the Alaska Field Operations Center (AFOC), Alaska Technology Transfer Office (ATTO), and various research centers of the USBM were active in the programs listed below; further information on the scope and nature of these programs can be found in appendix 2 .

Mineral land assessment.-The USBM's major emphasis in Alaska is the development of areal and commodityoriented mineral assessments. A major part of this program focuses on evaluations of mining districts in the State, including assessments of the type, quantity, distribution, reserves, and beneficiation potential of specific mineral deposits. The program also centers on strategic and critical mineral studies throughout Alaska. USBM scientists locate, map, and estimate the size and grade of mineral deposits; they also collect samples for metallurgic research (fig. 3).

Minerals availability.-The two computerized components of the minerals availability program are the Minerals Availability System (MAS) and the Minerals Industry Location System (MILS) data bases. MAS contains information on reserve estimates, mineral extraction and beneficiation methodologies, environmental constraints on mining, and cost analyses for selected major mineral deposits. MILS lists basic information on the identification and location of known mineral deposits.

Policy analysis.-The policy analysis program compiles analyses of mineral data with respect to local and national needs. Technical, institutional, political, social, and economic parameters are used to identify mineral issues.

State mineral activities.-A USBM Alaskan State Mineral Officer compiles and analyzes mineral data to report on activities and trends within Alaska's mining industry.

Minerals research.-Minerals research in Alaska includes efforts to improve mining technology, mineral extraction, and environmental aspects of the mineral industry, while considering Alaska's distinctive climate and geologic conditions. Research is administered either by one or more of the nine USBM research centers in the lower 48 states or by Washington headquarters, as is the case with university cooperative programs such as the Mineral Institutes. Although funded by the USBM, Mineral Institutes utilize university staff and facilities to conduct their work. The University of Alaska-Fairbanks and the University of Mississippi were active in the State in 1989.

Much of the USBM's work involves high-risk, longrange research that promises major technological improve-

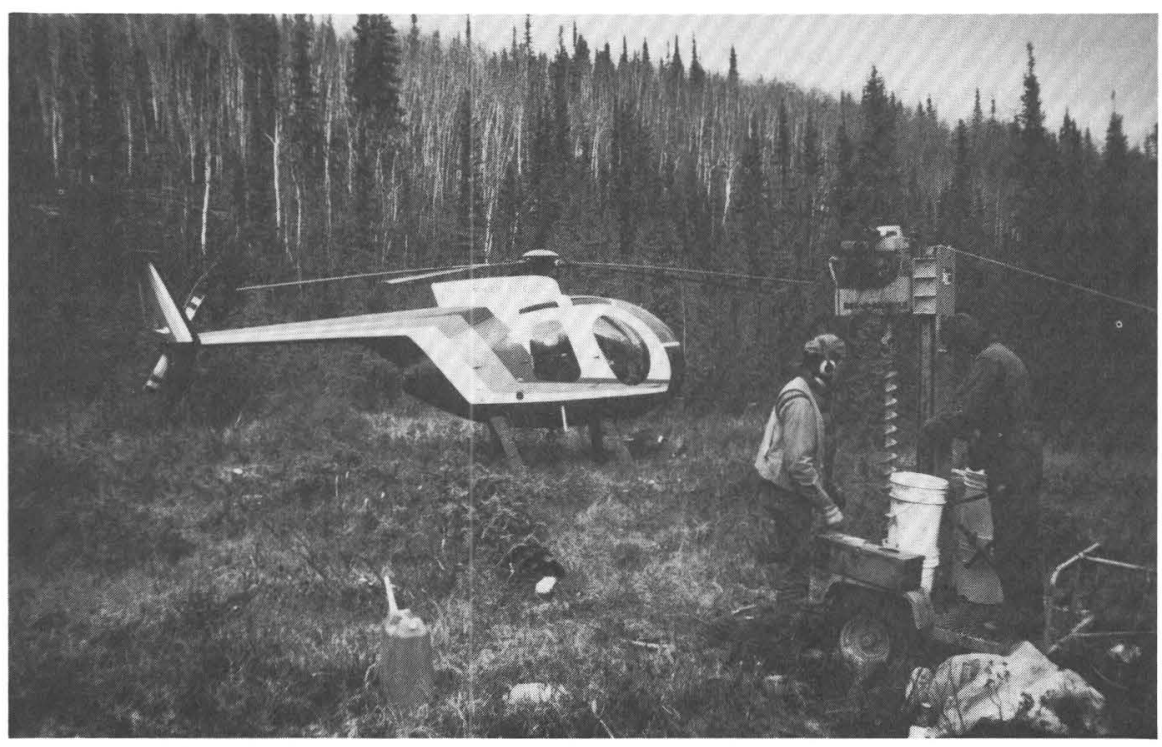

Figure 3. USBM geologists using helicopter-portable auger to sample placer tin and rareearth-element deposits in central Alaska. Photograph by J. Barker. 
ments. Corporate industry often cannot afford to conduct such research; the Nation, however, cannot afford to do without it. A primary goal of this research mission is the communication of USBM research results to industry, government, and the general public. ATTO gives mining companies and government agencies quick access to the USBM's latest technical developments. Publications, seminars, and presentations help introduce the results of USBM research, fact-finding, and analytical work to the widest possible audience.

\section{Minerals Management Service}

The MMS manages the exploration and development of mineral resources on Federal OCS lands. Although management efforts are largely focused on offshore oil and gas exploration and development, the MMS also has the authority to lease OCS lands for ocean mining of hard minerals.

Prior to an OCS lease offering, the MMS appraises the economic worth of leasable offshore territory and assesses the environmental risks associated with development of resources on or beneath these lands. Following a thorough process of public review and comment, the MMS selectively makes these areas available to interested parties through competitive OCS lease sales. The MMS then regulates post-lease exploration, development, and production activities to ensure that operations are conducted in a safe and environmentally acceptable manner. MMS-conducted inspections of operations ensure compliance with the applicable laws, regulations, and terms of the lease. Finally, the MMS is responsible for the collection and accounting of royalty and rental revenues generated by the leased properties. At present, no development or production of mineral resources is occurring on the Alaskan OCS.

The MMS does not manage onshore exploration and development of Federal mineral commodities in Alaska, but it is responsible for the collection of royalties, bonus payments, and lease rentals generated from onshore Federal and certain Native lands. In 1989, the State of Alaska received $\$ 8.9$ million in Federal mineral revenues from oil, gas, and mining. Productive leases in the Beaver Creek and Swanson River oil and gas fields, as well as the Beluga, Cannery Loop, and Kenai gas fields, provided the bulk of this revenue. More specific data on production and earnings from these fields may be obtained from MMS Royalty Management, Lakewood, CO 80225.

The MMS also conducts regional studies of the geologic history and petroleum potential of Alaska's offshore basins for the National Resource Assessment, the MMSUSGS inventory of America's oil and gas resources. Results of these studies have been published as part of the MMS OCS report series. A list of titles is provided in appendix 1. Copies of these reports may be obtained from the MMS regional office library in Anchorage.

\section{Bureau of Land Management}

The principal activities of the BLM that are related to Alaska's onshore mineral and energy resources are (1) assessment of the mineral potential of BLM planning areas and, through the planning process, identification of how the minerals can best be managed under the multiple-use concept, (2) development of the terms and conditions, through the planning process and environmental review in accordance with the National Environmental Policy Act (NEPA), for mineral exploration and development on BLM lands, (3) providing mineral resource and economic evaluations to determine mineral values for leasing and issuance of mineral leases and management of lease activity on Federal lands, coordinating with the responsible surface-managing agency where appropriate, (4) recording of mining claims and determination of the validity of claims for mineral patents, and (5) regulation of mining activities on BLM lands in order to protect the environment. The BLM is also responsible for enforcing the environmental and technical stipulations of the Agreement and Grant of Right-of-Way for the Trans-Alaska Pipeline, the overall goal of which is to maintain a continuous supply of energy with minimal environmental impact. In addition, the BLM issues landuse authorizations and conducts mineral and material sales to support preconstruction activities for the planned natural-gas pipeline and other projects. The BLM has also provided assessments of mineral-potential studies for other land-managing agencies, such as the FWS and NPS, and for input to congressional initiatives, such as the opening of the ANWR to leasing.

Administrative responsibilities for minerals require close coordination with other surface-management agencies. Generally, in the case of onshore leases, the BLM issues leases and integrates leasing with other land uses in cooperation with the surface-management agency. To ensure proper surface and subsurface protections after a lease is issued, the BLM enforces the regulations of 43 CFR 3160 with respect to the lease stipulations and permit conditions for exploration and development activities.

\section{Fish and Wildlife Service}

Mineral activities on FWS land in Alaska must conform to the agency's mission of protecting fish and wildlife and their habitats. In Alaska, FWS activities include administration of 77 million acres of national wildlife refuge land; fish and wildlife research; law enforcement; and habitat protection through agency review of and comments on permit requests, environmental impact statements, and other items. The FWS has an environmental-contaminants program that includes sampling and reporting on contaminants in waters, sediments, and organisms affected by oil and gas exploration and development, placer mining, and other mineral activities. 


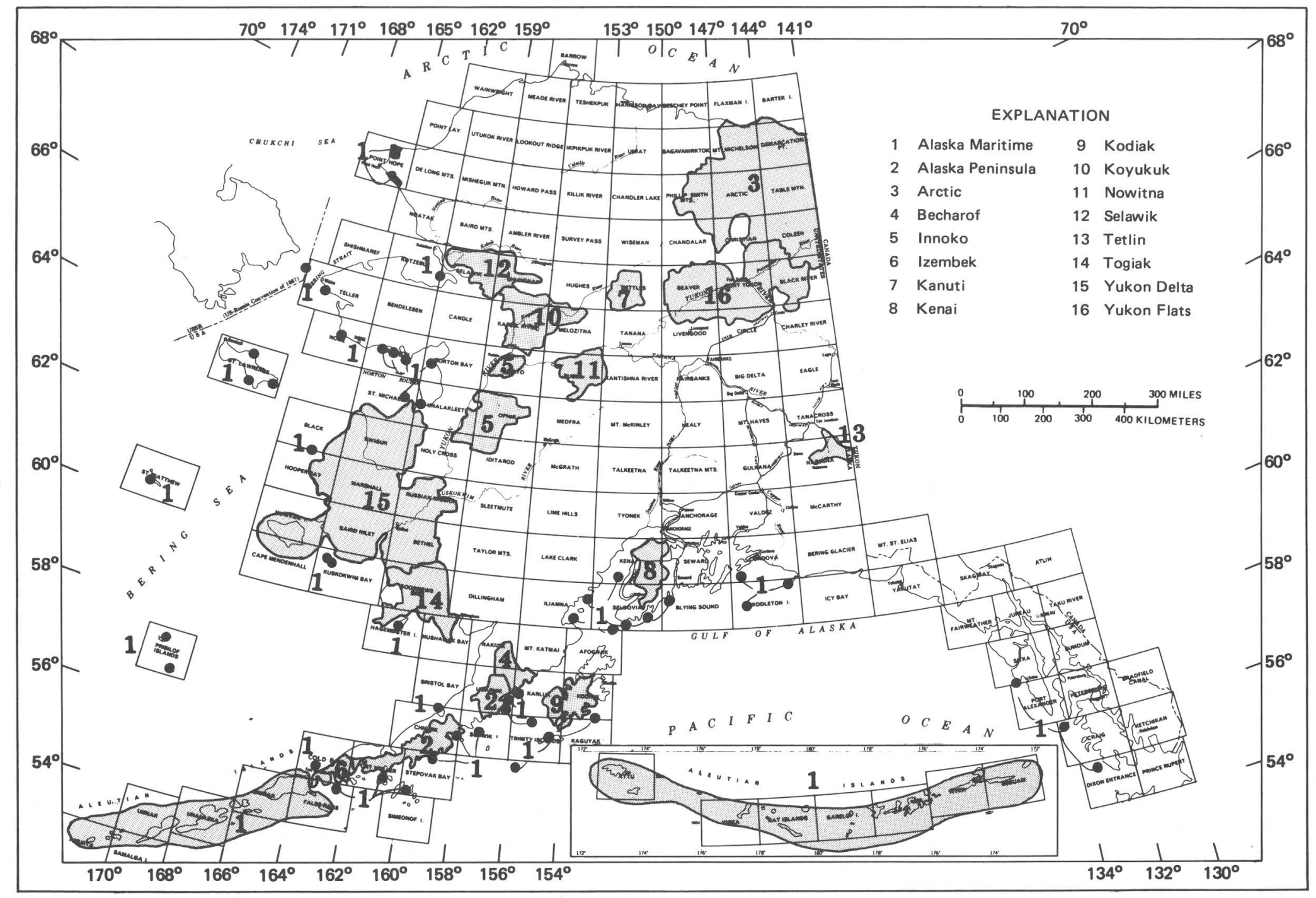

Figure 4. National wildlife refuges in Alaska. 1:250,000-scale quadrangles are outlined and labeled. 
The locations of the 16 national wildlife refuges managed by the FWS in Alaska are shown in figure 4.

\section{National Park Service}

The NPS does not manage minerals in the same sense as other Federal agencies because the vast majority of park units are closed by law to leasing, disposition, and mineral location. The NPS is directed by its Organic Act and other Federal laws to protect park resources and, more specifically, to protect them from significant adverse impacts that can result from mineral exploration and development activities. Minerals management programs of the NPS protect park resources by controlling activities relating to the exercise of valid existing rights. Valid existing rights are State, Native, and other private mineral or fee lands, or interests in lands whose ownership was typically established prior to the time the park unit was created. Examples of valid existing rights that are regulated by the NPS are patented and valid unpatented mining claims and non-Federal oil and gas rights.

NPS minerals management activities include mineral examinations to determine claim validity; evaluation of proposed mining plans including completeness determination, engineering analysis, impact assessment, and bonding; and compliance monitoring of approved operations. In Alaska, major programs have been undertaken to survey, aerially photograph, and map mining claims; to prepare topographic maps of mining claims (scale 1:1,200, 10-foot contour interval); to perform hydrologic monitoring; to reclaim abandoned or acquired mining claims; and to conduct reclamation research. Guidelines for NPS management and regulation of mineral-related activities are discussed in appendix 2.

\section{Department of Agriculture}

\section{U.S. Forest Service}

Under a memorandum of understanding with the BLM, the USFS jointly administers the general mining laws on its own lands in Alaska. An example of this joint responsibility is the patent issued to U.S. Borax and Chemical Company for mining claims at the Quartz Hill deposit near Ketchikan. The BLM issued this patent on the basis of favorable findings in a mineral report prepared by USFS mineral examiners.

The USFS cooperates with Department of the Interior (DOI) agencies, particularly the BLM, in issuing mineral leases and assuring mitigation of surface impacts of lease activities. The USFS also cooperates with the State of Alaska and the private sector in development of energy and mineral resources on inholdings. One such inholding is the Bering River coal field, under consideration for possible development in a joint venture by Chugach Alaska and others.
In Alaska, 23 million acres of land is administered by the USFS (fig. 1), whose regional office is in Juneau. Offices for the Chugach National Forest are in Anchorage, Girdwood, Seward, and Cordova, and for the Tongass National Forest in Sitka, Ketchikan, and Petersburg.

\section{Department of Energy}

In Alaska, the DOE is focusing its efforts on petroleum, coal, and geothermal resources. The DOE in Alaska administers current petroleum acts and congressional mandates relating to energy, monitors grants, and oversees contracts for energy-resource studies. DOE funding helps support USGS resource-assessment studies and research by the ADGGS and the University of Alaska.

To develop a better understanding of both conventional and unconventional petroleum resources and to provide fundamental information to accelerate use of these resources, the DOE focuses on investigating resources and technologies that continue to expand the body of essential basic scientific knowledge of conventional and heavy petroleums, shale oil, tar sands, gas hydrates, and deepsource gas. Gas hydrates, deep-source gas, and Arctic offshore energy are specific targets of DOE research in Alaska.

The DOE is working to evaluate Alaskan coal in terms of its contribution to the total resources of the Nation. Coal research currently centers on utilization methods suitable to Alaskan coals and conditions.

The DOE has established several computerized data bases, including the Arctic and Offshore Research Information System (AORIS), which is a personal-computer (PC) data base designed to provide scientific oil- and gas-related information for use by the Arctic energy community. The tripartite AORIS is composed of a directory of 85 energyrelated data bases, a bibliography containing over 8,000 citations, and a quantitative data base on sea-ice characteristics containing over 800 data sets in both tabular and graphic formats.

The DOE closed its regional office in Anchorage in 1985. Requests for information about DOE Alaskan activities should be addressed to the office listed below.

\section{Contacts for Further Information}

\section{Department of the Interior}

Bureau of Land Management

Edward F. Spang, State Director

Federal Building

222 West Seventh Avenue, No. 13

Anchorage, AK 99513-7599 
Fish and Wildlife Service

Walter O. Stieglitz, Regional Director

1011 East Tudor Road

Anchorage, AK 99503-6119

Minerals Management Service

Alan D. Powers, Regional Director

Alaska OCS Region

University Plaza Building, Rm. 110

949 East 36th Avenue

Anchorage, AK 99508-4302

National Park Service

Boyd Evison, Regional Director

Alaska Regional Office

2525 Gambell Street, Room 107

Anchorage, AK 99503-2892

\section{U.S. Bureau of Mines}

Donald P. Blasko, Chief

Alaska Field Operations Center

201 East Ninth Avenue, Suite 101

Anchorage, AK 99501

\section{U.S. Geological Survey}

Donald Grybeck, Chief

Branch of Alaskan Geology

4200 University Drive

Anchorage, AK 99508-4667

Department of Agriculture

U.S. Forest Service

Michael Barton, Regional Forester

Alaska Region

P.O. Box 21628

Juneau, AK 99802

\section{Department of Energy}

Hydrocarbon resources

Joseph Lagler

Morgantown Energy Technology Center

P.O. Box 880, Collins Ferry Road

Morgantown, WV 26507

\section{ENERGY RESOURCES}

\section{Oil and Gas Resources}

\section{Overview of Production and Prices}

In 1989, as in the previous several years, oil and gas were again the most valuable commodities produced in Alaska. Alaska's two oil-producing areas, the Arctic North Slope and Cook Inlet (fig. 5), provided a total of 702 million barrels ( $1 \mathrm{barrel}=42$ U.S. gallons) of oil and natural gas liquids, 195 billion cubic feet of dry natural gas, and 1,780 billion cubic feet of casinghead gas in 1989 (Alaska Oil and Gas Conservation Commission Bulletin, February 1990). This represents a decrease from 1988 of 7.5 percent for oil, the first drop in Alaskan oil production since 1980, and an increase of 3.7 percent for gas. The rate of oil production in Alaska at the end of 1989 amounted to 1.9 million barrels per day (bbl/d), or about 25 percent of U.S. daily production; this places Alaska second among the oilproducing states.

World oil prices remained at 1988 levels until midAugust 1989, then rose gradually to close out the year at $\$ 19 / \mathrm{bbl}$ (fig. 6). Conversely, the price of Alaska North Slope (ANS) crude oil, as reported by BP Exploration (table 1), increased steadily in the first five months of 1989 to a high of $\$ 19.33 / \mathrm{bbl}$ for oil delivered to the west coast $(\$ 19.97 / \mathrm{bbl}$ to the Gulf Coast), then declined from June through September before rising again in the fourth quarter. Generally, prices for crude delivered to the west coast averaged $\$ 16.59$ / bbl ( $\$ 17.24 / \mathrm{bbl}$ to the Gulf Coast), about $\$ 3 / \mathrm{bbl}$ more than in 1988. Alaska's economy is especially vulnerable to fluctuations in the price of crude oil because 83 percent of the State's current revenue is derived from royalties and taxes paid on State-owned oil and gas leases (Alaska Department of Natural Resources, 1986). Each $\$ 1$ change in the price of crude oil equals approximately $\$ 150$ million gain or loss in State revenues.

Following the Exxon Valdez oil spill in March 1989, the Alaska State legislature increased the severance tax on oil produced from the Prudhoe Bay and Kuparuk River fields by 20 percent and 65 percent, respectively (Alaska Report, June 7,1989 ). The impact of this increased taxation along with fluctuating oil prices was reflected in many industry activities: development of the Hurl State and West Sak projects was postponed, and some development drilling in the Kuparuk River field was delayed; on the other hand, the Milne Point oil field, in a "warm shutdown" mode since 1986, resumed production in April 1989 due to improved oil prices.

In June, the seven-billionth barrel of North Slope crude oil was produced. Overall production from the North Slope averaged about $95,000 \mathrm{bbl} / \mathrm{d}$ less in 1989 than in 1988 (Alaska Report, December 27, 1989). About one-third of the reduced production was attributable to the Exxon Valdez 


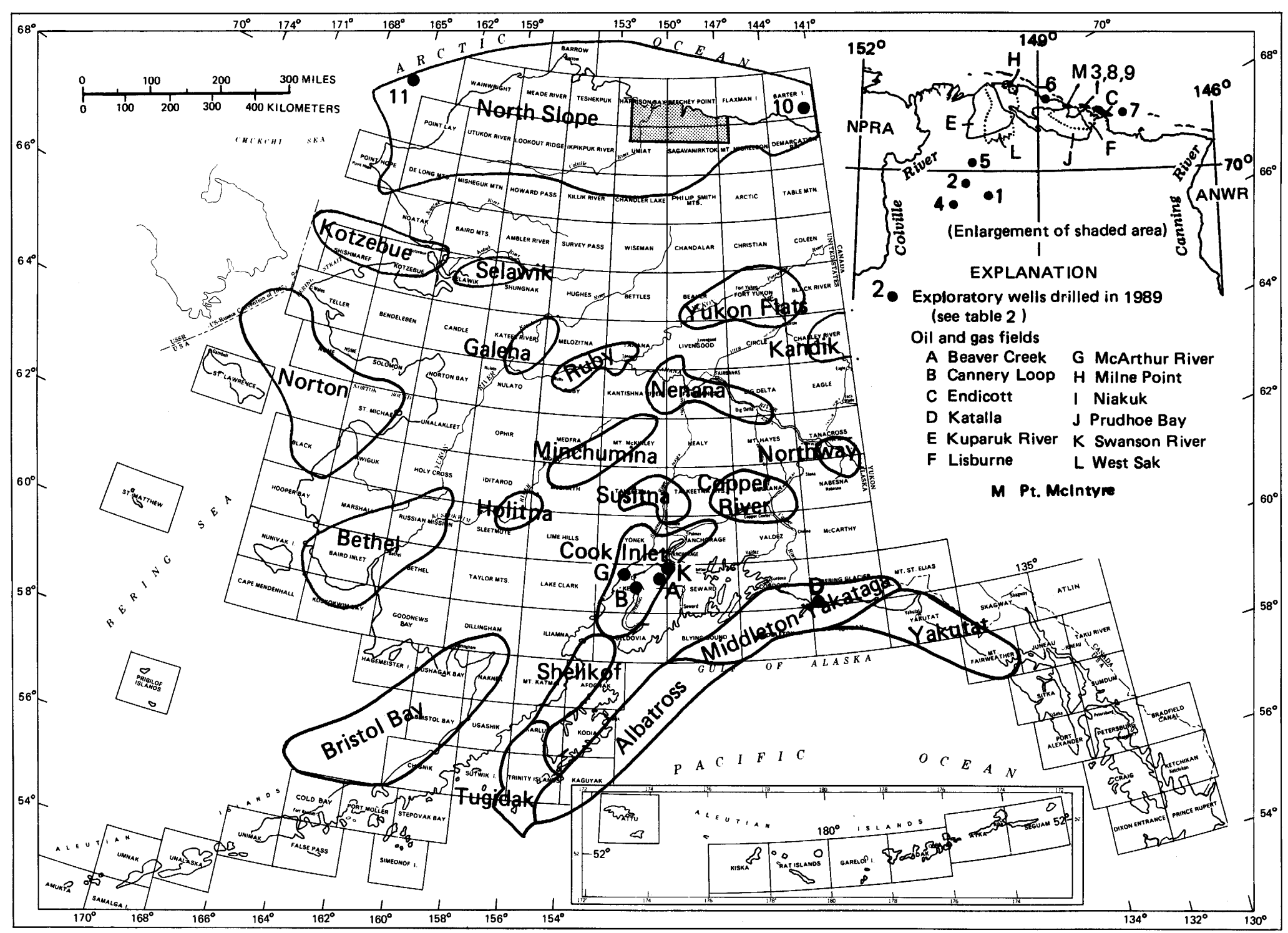

Figure 5. Locations of exploratory oil wells drilled in 1989, oil and gas fields, and possible petroleum-bearing sedimentary basins (outlined). Basins adapted from Kirschner (1988). 1:250,000-scale quadrangles are outlined and labeled. 
oil spill, and the remaining decline in production was the result of maintenance undertaken by the fields' operators.

\section{Exploration}

Fifteen exploratory wells were active in Alaska in 1989: nine on the North Slope, three in the Beaufort Sea planning area, and three in the Chukchi Sea planning area (Alaska Oil and Gas Conservation Commission Bulletin, May 1990). The nine North Slope wells were all completed (fig. 5, table 2), twice the number drilled in 1988. One Beaufort well and one Chukchi well were also completed. By mid-December, the State of Alaska had issued 132 drilling permits for 107 development wells, 10 exploratory wells, 14 service wells, and 1 stratigraphic test (Alaska Report, January 3, 1990).

During 1989, a new oil field was discovered by Arco Alaska and its partners, Exxon USA and BP Exploration. Located just 2 miles north of the Prudhoe Bay field (fig. 5), the Point McIntyre field is reported to contain $\mathbf{3 0 0}$ million barrels of recoverable oil. Discovered by deepening an earlier drilled well (Point McIntyre No. 3) and outlined by two other wells (Point McIntyre No. 4 and No. 5), the field lies just offshore in State waters on the west side of Prudhoe Bay. It is the largest oil discovery in Alaska since BP Exploration's Endicott field discovery of $\mathbf{3 5 0}$ million barrels of recoverable oil in 1978.

Shell Western Exploration and its partners initiated a wildcat drilling program in the Chukchi Sea. A total of eight wells are planned. After penetrating 12,000 feet, the first exploratory well was completed in September at the Klondike prospect. Taking advantage of the favorable weather conditions, the Canmar Explorer III drilling rig was then moved to two more sites. At the Burger prospect, pen-

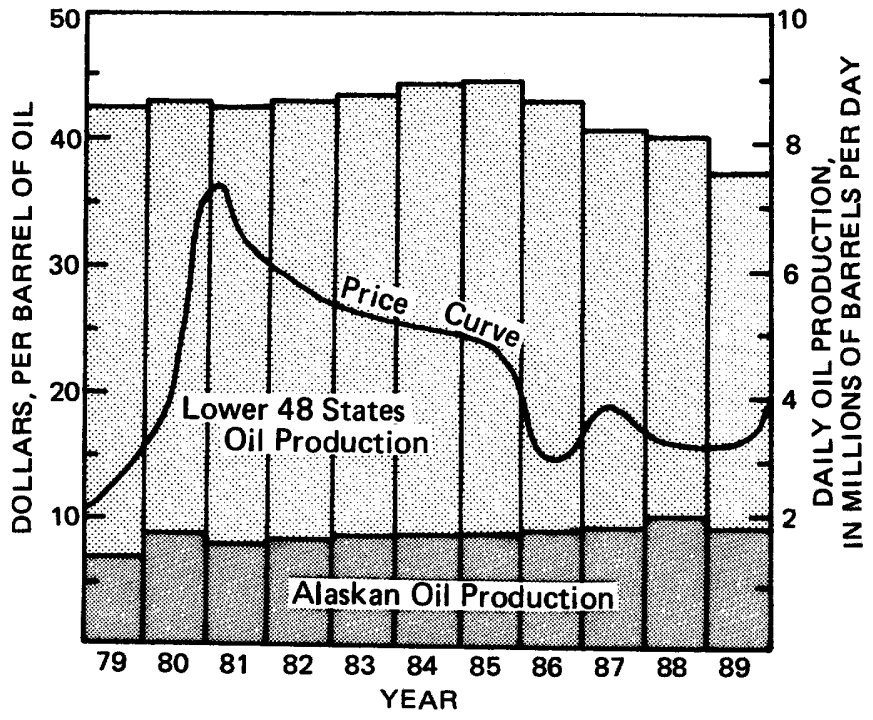

Figure 6. Average annual United States oil production and worldwide price of oil for 1979-1989.
Table 1. Fluctuation in price of Alaska North Slope crude oil

[Data from Alaska Reports; BP Exploration's Alaska North Slope contract crude oil price represents 95 percent of production; WC, delivered to west coast; GC, delivered to Gulf of Mexico]

\begin{tabular}{rrr}
\hline \multirow{2}{*}{ Date } & \multicolumn{2}{c}{ Cost per barrel } \\
\cline { 2 - 3 } & WC & GC \\
\hline $12 / 7 / 88$ & $\$ 10.68$ & $\$ 11.68$ \\
$1 / 4 / 89$ & 13.35 & 14.35 \\
$2 / 8 / 89$ & 15.30 & 16.30 \\
$3 / 8 / 89$ & 15.38 & 16.38 \\
$4 / 5 / 89$ & 17.13 & 17.67 \\
$5 / 8 / 89$ & 19.33 & 19.97 \\
$6 / 7 / 89$ & 17.55 & 18.04 \\
$7 / 12 / 89$ & 16.94 & 17.43 \\
$8 / 2 / 89$ & 16.70 & 17.21 \\
$9 / 6 / 89$ & 16.02 & 16.48 \\
$10 / 4 / 89$ & 16.59 & 17.07 \\
$11 / 8 / 89$ & 17.21 & 17.80 \\
$12 / 6 / 89$ & 17.52 & 18.05 \\
$1 / 3 / 90$ & 19.05 & 19.52 \\
\hline
\end{tabular}

${ }^{1}$ Contract price based on average of spot market price for Alaska North Slope crude for prior month. Price is set at beginning of each month (Alaska Report May 11, 1988).

etration reached 5,500 feet; the third well was started on the Popcorn prospect before ice conditions required termination of the 1989 drilling season. Texaco and its partners, which hold 84 leases, also announced plans to drill 21 exploratory wells in the coming years. Governor Steve Cowper continues to seek joint U.S.-U.S.S.R. programs for exploration and development in the Chukchi Sea.

Seismic surveys were conducted in the MatanuskaSusitna Borough in anticipation of State lease sale 67-A, currently scheduled for September 1990. Areas of offshore seismic-reflection work include the Beaufort Sea (1,788 linemiles of data), the Chukchi Sea (4,335 line-miles), the Gulf of Alaska (1,050 line-miles), and lower Cook Inlet (550 line-miles). To date, over one million line-miles of geophysical data have been acquired by private and public concerns in offshore Alaska's OCS planning areas.

Effects of oil spills.-Prior to the Exxon Valdez oil spill on March 24, 1989, in which 11 million gallons of oil was released into Prince William Sound, a variety of legislative proposals, plans, programs, and agreements related to oil and gas development were being discussed throughout the State, in the halls of Congress in Washington, among Native corporations, and in the petroleum industry. Areas of particular interest involved the Arctic National Wildlife Refuge (ANWR), the Beaufort Sea, Bristol Bay, and the 
Table 2. Alaska exploratory oil wells drilled in $\mathbf{1 9 8 9}$

[See figure 5 for locations. P\&A, plugged and abandoned; N/A, not available]

\begin{tabular}{|c|c|c|c|c|c|c|c|}
\hline $\begin{array}{l}\text { Well } \\
\text { No. }\end{array}$ & Company & Well name & API No. & Location' & $\begin{array}{c}\text { Total } \\
\text { depth } \\
\text { (feet) }\end{array}$ & $\begin{array}{c}\text { Date } \\
\text { completed } \\
(1989)\end{array}$ & Remarks \\
\hline 1. & Texaco & Wolfbutton 25-6-9 & $50-223-20017$ & $25-6 \mathrm{~N}-9 \mathrm{E}$ & 10,241 & $2 / 12$ & P\&A \\
\hline 2. & Texaco & Wolfbutton 32-7-8 & $50-287-20008$ & $32-7 N-8 E$ & 9,550 & $2 / 16$ & - $\quad$ P\&A \\
\hline 4. & BP & Kuparuk Uplands No. 1 & $50-287-20009$ & $17-5 N-7 E$ & 6,100 & $3 / 16$ & P\&A \\
\hline 5. & Unocal & Ruby State No. 1 & $50-103-20104$ & $14-8 \mathrm{~N}-8 \mathrm{E}$ & 3,850 & $3 / 20$ & P\&A \\
\hline 6. & ARCO & West Storkerson No. 1 & $50-029-21913$ & $15-12 \mathrm{~N}-13 \mathrm{E}$ & 9,146 & $3 / 25$ & P\&A \\
\hline 7. & Chevron & Karluk No. 1 & $50-629-21897$ & $11-11 N-18 E$ & 11,190 & $4 / 7$ & P\&A \\
\hline 10. & Amoco & OCS-Y-0917 No. 1 & $55-141-00005$ & $70^{\circ} 2752^{\prime \prime N}$ & 13,150 & $8 / 28$ & P\&A \\
\hline & & (Belcher) & & $141^{\circ} 51^{\prime} 27^{\prime \prime} \mathrm{W}$ & & & \\
\hline \multirow[t]{2}{*}{11.} & Shell & OCS-Y-1482 No. 1 & $55-381-00001$ & $70^{\circ} 42^{\prime} 39^{\prime \prime} \mathrm{N}$ & N/A & $9 / 15$ & P\&A \\
\hline & & (Klondike) & & $165^{\circ} 1459^{\prime \prime} \mathrm{W}$ & & & \\
\hline
\end{tabular}

'Location for onshore and State offshore wells given in section-township-range within Umiat meridian; for Federal offshore wells, latitude and longitude is given.

Chukchi Sea. As a result of the Valdez and several other smaller spills around the state, many efforts to expand exploration or production came to a standstill or were the subject of vehement opposition, and tighter environmental restrictions were sought.

In Bristol Bay, the threat and eventual implementation of a one-year ban on drilling, fomented by the State and local fishing industry, resulted in the Chevron Corporation curtailing its plans to pursue permits on what would have been industry's first wildcat well in this offshore area. The U.S. Supreme Court, however, left intact the ruling that will still allow leasing in 5.6 million acres of Bristol Bay.

The industry's expectation for exploration in ANWR was also dashed by the Exxon Valdez spill. Results of the KIC No. 1 exploratory well, drilled just north of the 1002 area on Native land owned by the Arctic Slope Regional and Kaktovik Inupiat Native Corporations, remain confidential. In August 1989, an environmental consortium and the Gwich'in Native people filed separate lawsuits, contending that the government's 1002 (h) report to Congress in 1987 was deficient and should be supplemented.

\section{Production Activity}

Industry activities for onshore Alaska in 1989 included delineation drilling of the Point McIntyre oil field, oil production startup in the Milne Point field, and continued development drilling in nine other fields. A total of 130 development and service wells were active: 12 in Cook Inlet, 13 at the Endicott field, 31 at Kuparuk River, 6 at Milne Point, and 68 at Prudhoe Bay (Alaska Oil and Gas Conservation Commission Bulletin, May 1990). Little information on these wells has been released to the public, but some data are made available through private subscription services, such as the weekly Alaska Report published by the Petroleum Information Corporation.

As of November 1989, Alaskan oil production was $95,000 \mathrm{bbl} / \mathrm{d}$ less than the same time a year earlier, while total United States oil production was running at a rate $540,000 \mathrm{bbl} / \mathrm{d}$ less than in 1988 (Alaska Report, December 27, 1989). Some of this reduction was due to problems associated with the Trans-Alaska Pipeline (see Transportation).

\section{North Slope}

Prudhoe Bay field.-BP Exploration awarded engineering and construction contracts for a planned $\$ 70$ million expansion of its water-processing facilities at the Prudhoe Bay field. These processing units separate out water and gas from the oil produced for reinjection back into the oil reservoir (Alaska Report, September 20, 1989). 
Lisburne field.-The State Division of Oil and Gas substantially lowered the amount of oil deemed recoverable from the Lisburne pool in the Prudhoe Bay field (fig. 5). The original estimate of 380 million barrels was downscaled to about 165 million barrels of recoverable oil (Alaska Report, August 30, 1989).

Endicott field.-BP Exploration figures show that the Endicott field is the sixth largest producing field in the United States. During 1989, the field produced 97,933 bb1/ d, surpassing the East Texas field's $96,594 \mathrm{bbl} / \mathrm{d}$ (Alaska Report, January 24, 1990). Production from the Endicott field began in 1987; to date, the field has produced some 83 million barrels of oil. The five largest producing fields in the Nation are the Prudhoe and Kuparuk River fields on Alaska's North Slope, and the South Belridge, MidwaySunset, and Kern River fields in California.

Milne Point field.-The Milne Point field resumed production of 7,000 bbl/d in April 1989 after being shut down for about 2 years due to low oil prices. Milne Point is the smallest producing field on the North Slope, with estimated reserves of 100 million barrels of oil. Conoco plans eventually to increase production to $32,000 \mathrm{bbl} / \mathrm{d}$ by drill- ing additional production wells and by instituting a program of reservoir enhancement that includes pressure maintenance to ensure a uniform flow to the wells and acidization and (or) fracture stimulation to increase reservoir permeability.

\section{Cook Inlet}

Increased demand for local gas consumption has prompted Unocal to begin the construction of facilities for transporting production from the Ivan Lake and Stump River gas fields on the west side of Cook Inlet. These fields have been shut-in since their discovery in 1961 and 1978, respectively (Alaska Report, March 8, 1989).

The Drift River oil terminal, 90 miles southwest of Anchorage, provides crude-oil storage for the offshore oil platforms on the west side of Cook Inlet. On December 14, 1989, the nearby Mount Redoubt volcano erupted for the first time since 1966. Water, mud, and rock from the volcano's flanks flowed 21 miles down the Drift River, engulfing the terminal at the river's mouth (fig. 7). The 12foot-high earthen dikes encircling the seven storage tanks

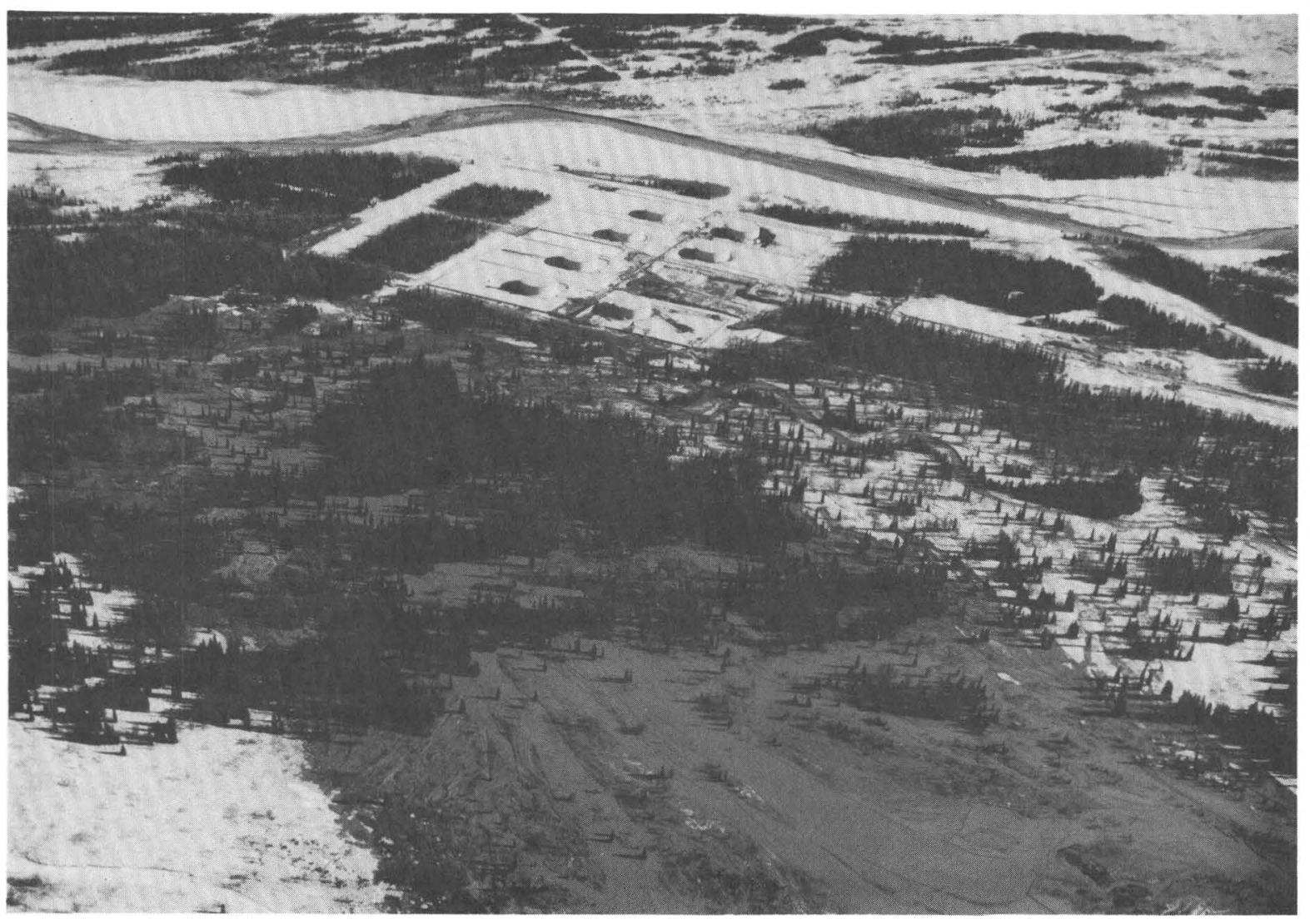

Figure 7. Drift River oil terminal. Debris flow from December 14, 1989, eruption of Mount Redoubt can be seen in foreground. Photograph by C. Gardner. 
were not breached, but personnel were evacuated until the danger had passed. Another debris flood in early January 1990 knocked out all power at the terminal, shutting down the facility. With no other storage available, the offshore platforms were forced to suspend production (Anchorage Times, January 10, 1990); operators worried that prolonged shutdown would adversely affect the long-term recovery of oil from the Cook Inlet fields. In mid-January, environmental concerns for a potential 36-million-gallon spill, if the storage tanks were breached, prompted the removal of oil already stored at Drift River. The terminal and platforms were operating again by the end of the month, but continuing eruptions caused repeated shutdowns throughout early 1990.

\section{State Activity and Lease Sales}

During 1989, State agencies conducted two competitive oil and gas lease sales on the North Slope (table 3, fig. 8), monitored and supervised lease development, collected lease rents and production royalties, and conducted numerous geologic and geophysical studies relating to oil and gas resource evaluation and land classification. These studies are only briefly reported in this circular. The Alaska Department of Natural Resources (ADNR) Information Circular 31, "Oil and gas resources of Alaska," presents an overview of the history of exploration and development, current prospects, resource estimates, and the State's leasing program.

At the two State lease sales, a total of $\$ 2.1$ million was offered in high bids to acquire approximately 176,658 acres for future exploration. Only five companies participated in these sales. The terms of these leases can be obtained from the Lease Administration Office, ADNR, P.O. Box 107034, Anchorage, AK 99510. For further information about State petroleum-related activities, readers should contact the Alaska Division of Oil and Gas, 3601 C Street, Anchorage, AK 99503.

Following the Exxon Valdez oil spill, ADNR rescheduled the two remaining 1989 lease sales (67A, Cook Inlet; 70A, Kuparuk Uplands) for 1990; three future sales (59, Cook Inlet; 73A, North Slope; 56, Alaska Peninsula) were canceled completely. The other scheduled sales were unaffected (Alaska Report, June 14, 1989). In October, the State Division of Oil and Gas added three oil and gas lease sales to its program (78, Cook Inlet; 79, Yakataga; 80 Shaviovik)(Alaska Report, October 18, 1989).

Two private oil and gas lease sales were held in 1989. Cook Inlet Region Incorporated (CIRI), an Alaska Native corporation, held a lease sale for acreage located in the Moquawkie and Albert Kaloa gas fields on the west side of Cook Inlet. Twenty-six tracts covering 58,538 acres were offered to invited bidders only. Ultimately, a single bidder acquired one tract covering 1,800 acres (Alaska Report, November 1, 1989). On the North Slope, two leases covering 5,093 acres were offered by Fairbanks independ-
Table 3. State of Alaska oil and gas lease sales, 1989

[Areas shown in figure 8; sales conducted by State of Alaska, Department of Natural Resources, Division of Oil and Gas; data from Alaska Report, January 25, 1989]

\begin{tabular}{|c|c|c|}
\hline $\begin{array}{l}\text { Sale name } \\
\text { Sale number- }\end{array}$ & $\begin{array}{l}\text { Beaufort Sea } \\
52\end{array}$ & $\begin{array}{c}\text { Kuparuk River } \\
\text { 72A }\end{array}$ \\
\hline Sale date (month/day/year): & $01 / 24 / 89$ & $01 / 24 / 89$ \\
\hline Cash bonus bid with fixed royalty of: & $12.5 \%$ & $12.5 \%$ \\
\hline Total bids received: & 20 & 1 \\
\hline Tracts offered: & 43 & 1 \\
\hline Tracts sold: & 15 & 1 \\
\hline Acreage offered: & 175,981 & 677 \\
\hline Acreage sold: & 52,463 & 677 \\
\hline Total high bonus bids: & $\$ 1,737,513$ & $\$ 454,997$ \\
\hline Total exposure (sum of all bids): & $\$ 1,959,057$ & $\$ 454,997$ \\
\hline Average bid per acre: & $\$ 33.12$ & $\$ 672.08$ \\
\hline Highest bid for a tract: & $\$ 413,575$ & $\$ 454,997$ \\
\hline Highest per-acre bid: & $\$ 94.04$ & $\$ 672.08$ \\
\hline
\end{tabular}

ent, Cliff Burglin. Doyon Drilling Incorporated acquired the leases at auction in Oklahoma City for $\$ 1.50 /$ acre (Alaska Report, May 9, 1990).

\section{Transportation}

Trans-Alaska Oil Pipeline.-The seven-billionth barrel of crude oil flowed through the Trans-Alaska Pipeline System (TAPS) on June 30, 1989. Flow through the pipeline now averages about 2 million $\mathrm{bbl} / \mathrm{d}$, at a current surcharge of $\$ 3.90 / \mathrm{bbl}, \$ 0.86 / \mathrm{bbl}$ higher than one year ago. The higher cost reflects a slight decline in flow rate as well as the need to raise revenues for repairs stemming from pipeline corrosion.

Through a new application of corrosion detection technology, two hundred sites along TAPS have already been inspected with "pigs," instruments that travel inside the pipe and map the integrity of its walls. All corrosion detected on the mainline has been external and is restricted to buried sections of the system. The two causes of corrosion have been identified as (1) poorly applied pipe coating and (2) breaching of the coating by rocks in the pipe bed. Nine miles of corroded pipe in the Atigun Pass area will be replaced during the spring of 1991; buried sections north of Fairbanks and near the Valdez marine terminal also require replacement.

Internal deterioration along TAPS has been identified at the pumping stations in pipes that are used only occasionally for moving oil. When oil sits in these "deadleg" pipes, water settles out and can cause corrosion. A program is under way to remove all unnecessary "dead-leg" pipes and to install corrosion-inhibiting systems in the remaining ones. 


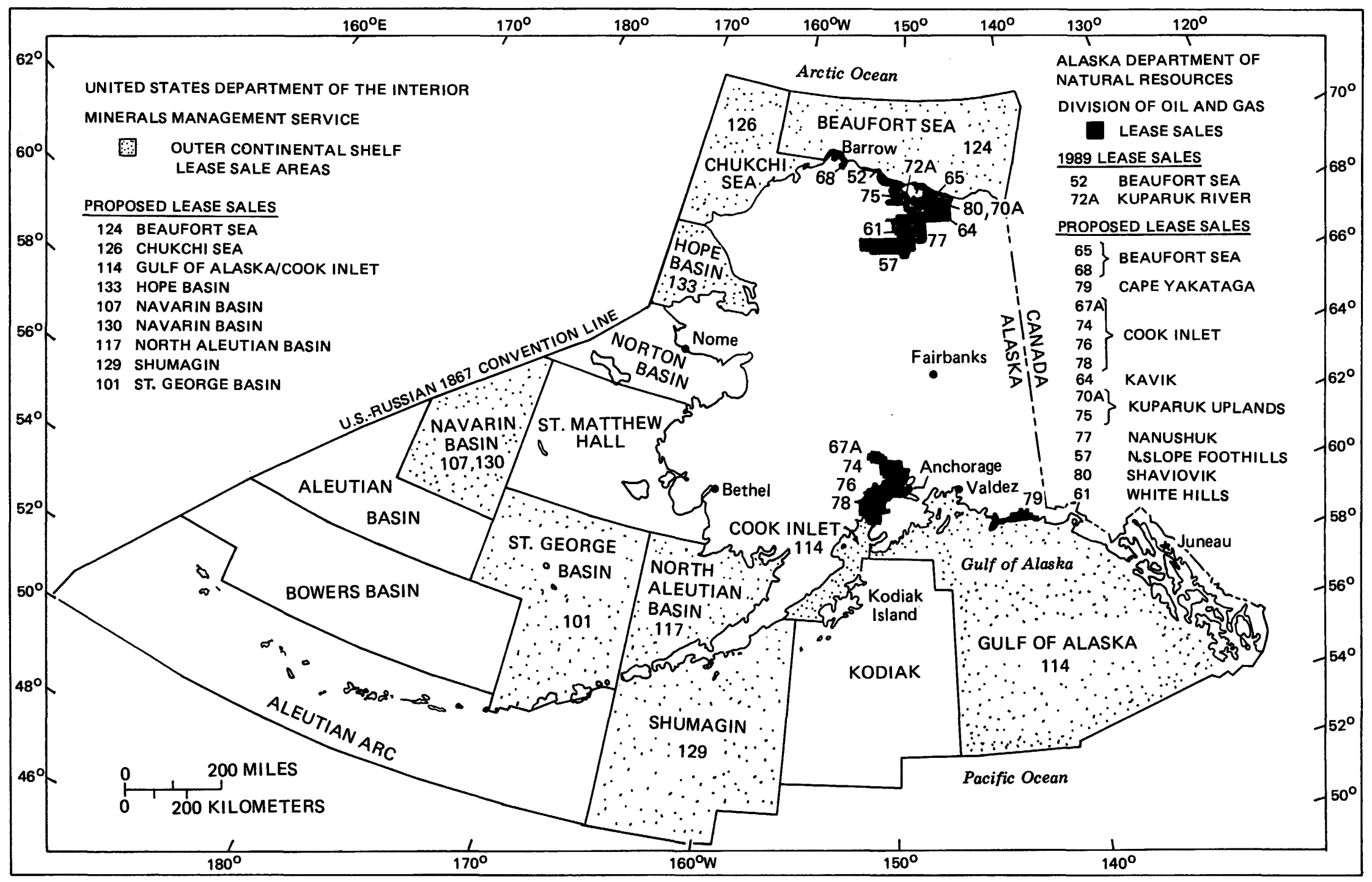

Figure 8. Areas of oil and gas lease sales and Alaska OCS Region planning areas (area boundaries based on MMS protraction diagrams, November 1986). 
Oil production on the North Slope was reduced several times in 1989 to accommodate a reduced flow of oil through TAPS. High winds early in the year caused partial to complete shutdowns. A partial shutdown to 65 percent of flow occurred for 3 days in January when winds averaging $60 \mathrm{mph}$ prompted the U.S. Coast Guard (USCG) to close the entrance to Valdez harbor. With no tankers to load oil from the North Slope, storage tanks began to approach capacity, and flow through the pipeline was reduced from 2 million bbl/d to $775,000 \mathrm{bbl} / \mathrm{d}$ (Alaska Report, February 1, 1989). Complete shutdown of the pipeline for about 8 hours occurred in February when high winds on the North Slope blew snow into the pumps at Pump Station \#1, causing a short in the electrical systems (Alaska Report, March 1, 1989). The amount of shortfall due to this shutdown was about 800,000 barrels of oil. Following the Exxon Valdez oil spill in Prince William Sound in March, tanker traffic was again restricted, necessitating a third slowdown in the throughput of TAPS; total reduction in output was about 6 million barrels of oil. Pipeline repairs to a corroded segment of the pipe just north of Atigun Pass also necessitated a reduced flow of $500,000 \mathrm{bbl} / \mathrm{d}$ in October.

Gas Pipeline.-Enormous reserves of natural gas exist on Alaska's North Slope. Current estimates range from 16.4 trillion to 304 trillion cubic feet, worth $\$ 90$ billion to $\$ 1,500$ billion at current prices. In 1989 , the DOE granted to Yukon Pacific Corporation a permit to export up to 660 billion cubic feet of natural gas per year to Pacific Rim countries; buyers will most likely be Japan, South Korea, and Taiwan (Geotimes, January 1990). Estimates of $\$ 11$ billion for the Trans-Alaska Gas System (TAGS) include the cost of constructing an 800-mile-long gas pipeline parallel to the existing oil pipeline, a conditioning liquifiednatural-gas plant, and tankers to ship the liquified gas. Given the abundance of natural gas resources on the North Slope, the TAGS pipeline would not necessarily compromise the proposed Alaska Natural Gas Transportation System (ANGTS), a 4,800-mile-long trans-Canadian pipeline to the lower 48 States. Cost estimates for the latter pipeline have been reduced recently from $\$ 14$ billion to $\$ 5.6$ billion; however, Canadian Native claims opposing its construction continue to cast uncertainty on the ANGTS project.

\section{Activity by Federal Agencies}

Minerals Management Service

$$
\text { Leasing Activity }
$$

Since 1976, LOI has held 15 OCS oil and gas lease sales on the continental shelves of offshore Alaska (fig. 8, table 4), offering over 98 million acres. Of this area, 8 million acres $(1,477$ leases) was leased by industry for cash bonus bids of over $\$ 6.4$ billion (table 5). Less than 1,000 leases remain active at present (approximately 5 million
Table 4. Alaska OCS leases and wells drilled, 1976-1989

[DST, deep stratigraphic test well]

\begin{tabular}{|c|c|c|c|}
\hline Planning area & $\begin{array}{c}\text { Number } \\
\text { of tracts } \\
\text { leased }\end{array}$ & $\begin{array}{c}\text { Number } \\
\text { of wells } \\
\text { drilled }\end{array}$ & $\begin{array}{c}\text { Number } \\
\text { of active } \\
\text { leases }\end{array}$ \\
\hline $\begin{array}{l}\text { Beaufort Sea } \\
(1979,1982,1984,1988)\end{array}$ & 574 & 21 & 495 \\
\hline Chukchi Sea (1988) & 350 & 3 & 350 \\
\hline $\begin{array}{l}\text { Cook Inlet Basin } 1 \\
(1977,1981,1982)\end{array}$ & 100 & 14 (1 DST) & 0 \\
\hline $\begin{array}{l}\text { Gulf of Alaska } \\
(1976,1980,1981)\end{array}$ & 112 & 13 (1 DST) & 0 \\
\hline Kodiak Shelf & & 6 (6 DST) & \\
\hline Navarin Basin (1984) & 163 & 9 (1 DST) & 23 \\
\hline $\begin{array}{l}\text { North Aleutian Basin }{ }^{2} \\
\text { (1988) }\end{array}$ & 23 & 1 (1 DST) & 23 \\
\hline Norton Basin (1983) & 59 & 8 (2 DST) & 6 \\
\hline St. George Basin (1983) & 96 & 12 (2 DST) & 30 \\
\hline
\end{tabular}

${ }^{1}$ Includes Lower Cook Inlet and Shelikof Straits.

2Preliminary injunction prohibited opening of bids and completion of sale until October 1988. Leases currently under 1-year moratorium and concurrent 1-year suspension of operations until September 30, 1990.

acres); the remainder have expired or have been relinquished. No lease sales were held on the Alaskan OCS during 1989.

Lease Status and Exploration

In the 14 years since OCS leasing began on the Alaskan outer continental shelf, 1,477 leases have been issued, and 14 deep stratigraphic test (DST) wells and 73 exploratory wells have been drilled (table 4). Most of the exploratory wells have been permanently plugged and abandoned; only eight leases have been classified as producible (Schneider, 1989, p. 20, table 6). As defined by MMS regulations 30 CFR 250.11, a producible lease is one from which oil, gas, or both can be produced in quantities sufficient to yield, after completion of the well, a return in excess of the cost of producing the hydrocarbons at the wellhead. The eight producible leases all lie within the Beaufort Sea planning area.

A total of 547 leases across the Alaskan OCS have been relinquished or have expired, leaving 930 leases still active as of December 31, 1989. These include the disputed lease areas discussed above.

Beaufort Sea planning area.-In the Beaufort Sea planning area, a total of 574 leases were awarded in four sales held in 1979, 1982, 1984, and 1988. Fourteen of these leases will expire by the end of 1990, 71 will expire in 1992, 211 will expire in 1994, and 98 will expire in 1998. The approaching expirations may stimulate accelerated 
Table 5. Proceeds from lease sales in Alaska OCS planning areas

\begin{tabular}{|c|c|c|c|}
\hline \multirow{2}{*}{$\frac{\text { Planning area }}{\text { Beaufort }}$} & \multicolumn{2}{|c|}{ Sale and year } & \multirow{2}{*}{$\frac{\text { Proceeds (\$) }}{488,691,138.00}$} \\
\hline & $\mathrm{BF}^{1}$ & (1979) & \\
\hline & 71 & (1982) & $2,055,632,335.65$ \\
\hline & 87 & (1984) & $866,860,327.00$ \\
\hline & 97 & (1988) & $115,631,636.00$ \\
\hline Chukchi & 109 & (1988) & $478,032,631.00$ \\
\hline \multirow[t]{3}{*}{ Gulf of Alaska } & 39 & (1976) & $559,836,587.00$ \\
\hline & 55 & (1980) & $109,751,072.96$ \\
\hline & RS-1 & (1981) & $170,496.00$ \\
\hline \multirow[t]{3}{*}{ Lower Cook Inlet } & CI & (1977) & $398,471,313.00$ \\
\hline & 60 & (1981) & $4,405,899.00$ \\
\hline & RS-2 & (1982) & 0.00 \\
\hline Navarin & 83 & (1984) & $516,317,331.00$ \\
\hline No. Aleutian & 92 & (1988) & $95,439,500.00$ \\
\hline Norton & 57 & (1983) & $317,873,372.00$ \\
\hline St. George & 70 & (1983) & $426,458,830.00$ \\
\hline
\end{tabular}

${ }^{1}$ Held jointly with State of Alaska: total sale revenues $\$ 1,056,082,635$.

drilling. A fifth lease offering, OCS Sale 124, is presently scheduled for 1991.

Twenty exploratory wells have been drilled in Federal waters in the Beaufort Sea planning area. The Belcher (OCS-Y-0917 No. 1) well was completed in 1989. Data from Karluk No. 1, drilled in State waters during 1989 (fig. 5, table 2), and several other Beaufort Sea wells remain proprietary at this time.

Chukchi Sea planning area.-The first lease sale in the Chukchi Sea planning area was held in 1988; the 350 leases currently active are all scheduled to expire in 1998. A second lease sale is scheduled for 1991.

Three exploratory wells have been drilled in the Chukchi Sea planning area. The Klondike (OCS-Y-1482 No. 1) well was completed in 1989 (fig. 5, table 2); the Burger (OCS-Y-1413 No. 1) and Popcorn (OCS-Y-1275 No. 1) wells were temporarily abandoned due to ice conditions and will be reentered in the 1990 drilling season.

Cook Inlet planning area.-In the Cook Inlet planning area, a total of 100 leases were granted in three sales held in 1977, 1981, and 1982. All have been relinquished or have expired.
Thirteen exploratory wells and one DST well were drilled in the Lower Cook Inlet and Shelikof Strait. All have been permanently plugged and abandoned.

Gulf of Alaska planning area.-In the Gulf of Alaska planning area, a total of 112 leases were issued in three OCS sales held in 1976, 1980, and 1981. All of these leases have been relinquished or have expired. A joint offering of leases in the combined Lower Cook Inlet/Gulf of Alaska shelf (OCS Sale 114) has been postponed pending results of studies of the Exxon Valdez oil spill.

All 12 exploratory wells and the one DST well drilled in the Gulf of Alaska have been permanently plugged and abandoned.

Kodiak Shelf planning area.-Six DST wells were drilled in 1976 and 1977. No lease sales are currently scheduled for the Kodiak Shelf area.

Navarin Basin planning area.-In the Navarin Basin planning area, a total of 163 leases were awarded in a single sale in 1984. Twenty-three leases remain active at present and are due to expire in 1994; the remainder have been relinquished. A second lease sale is scheduled for 1991.

Eight exploratory wells and one DST well have been drilled in the Navarin Basin; all are permanently plugged and abandoned.

North Aleutian Basin planning area (Bristol Bay).The 23 leases awarded in the North Aleutian planning area are presently under a Federal one-year moratorium and concurrent one-year suspension-of-operations (October 1, 1989 to September 30,1990) for the purpose of evaluating environmental consequences of oil development on Bristol Bay fisheries. Pending completion of the moratorium and suspension, the expiration date of the leases will be extended by one year. One DST well has been drilled in the North Aleutian Basin.

Norton Basin planning area.-In the Norton Basin planning area, a total of 59 leases were granted in a single lease sale held in 1983. All but six leases have been relinquished. These leases are under a suspension-of-operations, pending resolution of a lawsuit brought by the Native village of Gambell. Six exploratory wells and two DST wells, all permanently plugged and abandoned, have been drilled in the Norton Basin.

St. George Basin planning area.-In the St. George Basin planning area, a total of 96 leases were issued in a single sale held in 1983. Only 30 of these leases remain active at present; these are due to expire in 1993. Ten exploratory wells and two DST wells, all now permanently plugged and abandoned, have been drilled in the St. George Basin.

\section{Future Sales}

There have been modifications to the MMS fiveyear lease sale schedule drawn up in April 1988. No oil or gas lease sales are scheduled in Alaska for 1990. In 1991, 
sales are scheduled for the Beaufort Sea (Sale 124, April), Navarin Basin (Sale 107, July), and Chukchi Sea (Sale 126, August) planning areas. Other sales scheduled are the St. George Basin (Sale 101, January) in 1992, and Hope Basin (Sale 133, February) and Norton Basin (Sale 120, September) planning areas in 1993 (fig. 8). Three sales have been postponed: Cook Inlet (Sale 114), pending outcome of studies on the consequences of the Exxon Valdez oil spill; North Aleutian Basin (Sale 117) through Congressional moratorium; and Shumagin planning area (Sale 129) for lack of industry interest.

\section{National Resource Assessment}

In the autumn of 1986, the MMS and the USGS jointly launched a national inventory of oil and gas resources. The USGS evaluated the resource potential of onshore areas and State of Alaska waters extending 3 miles from shore. The MMS was responsible for a similar assessment of offshore areas extending from the 3-mile limit to approximately 200 nautical miles seaward to include the OCS Exclusive Economic Zone (EEZ). Personnel from both agencies met in 1986 and 1987 to review and coordinate the geologic interpretations supporting the assessment. A further review and update was conducted by the MMS in 1989 for the January 1990 update; both data and methodologies were presented to the Association of State Geologists and the National Academy of Sciences. Comments by these latter organizations will be used to refine future assessment procedures.

The role of the MMS Alaska OCS Region in this study was to estimate the amount of oil and gas resources that remain undiscovered on the continental shelf of offshore Alaska. Several OCS planning areas extend far seaward of the continental margins and include areas of deep oceanic basins. On the basis of logistical, economic, and geologic considerations, the areas seaward of the continental shelves in Alaska were considered to offer negligible resources. In addition, some planning areas were redrawn in order to obtain geologically rational boundaries. The outlines of the assessment provinces are shown in figure 9.

The results of the 1987 joint assessment were published in 1989 by the DOI (Mast and others, 1989). This publication updates similar inventories published by the USGS (Dolton and others, 1981) and by the MMS (Cooke, 1985).

\section{Joint State-Federal Studies}

In 1975, the MMS (then Conservation Division, USGS) and the State of Alaska initiated joint studies of the surface geology along certain coastal areas of Alaska where geologic data were of mutual interest and where such data promised insights into the petroleum potential of adjacent onshore and offshore areas. Past joint ventures have inves- tigated such areas as the Gulf of Alaska, Cook Inlet, Kodiak Island (Kodiak shelf), Seward Peninsula-Kuskokwim drainage (Norton Basin), Pribilof Islands (St. George Basin), Alaska Peninsula (North Aleutian Basin), Waring Mountains (Hope/Selawick Basins), and the northeastern Brooks Range (Kaktovik Basin). Since 1984, the cooperative work has been funded by grants from the Studies Related to Continental Margins Program, sponsored by the MMS and administered by the Bureau of Economic Geology, University of Texas at Austin. In recent years, the focus of the joint studies has shifted to the Arctic Slope and ANWR (fig. 8), where fission-track studies are tracing the thermal evolution of the Beaufort continental margin, particularly as it bears on the maturation history of key source rock sequences. Some early results of this work have been published separately by the ADGGS (O'Sullivan, 1988, 1989a,b; O'Sullivan and others, 1989).

\section{U.S. Geological Survey}

Current USGS petroleum research in Alaska focuses on the North Slope, several interior basins, and the Cook Inlet region, and on gas hydrates and thermal history studies of onshore oil and gas resources. These research projects are funded under the Oil and Gas Investigations Program and AMRAP; the gas-hydrates project is partially funded by DOE. Highlights from these programs were discussed during the 1990 McKelvey Forum, "Energy Research for the 1990's-Anticipating the Needs of the 21st Century," in Houston, Texas, February 20-22, 1990 (Carter, 1990). Other Federal studies in Alaska are summarized in USGS Bulletin 1946 (Dover and Galloway, 1990).

\section{North Slope}

Current petroleum geology studies on the North Slope, other than the gas-hydrate studies (described separately), include (1) a collaborative effort with the French Petroleum Institute to model the Cretaceous stratigraphic and tectonic development of the Canada basin and its rift margin, the Barrow arch, the Colville foreland basin, and the Brooks Range orogen by utilizing the extensive geologic-geophysical data set collected from NPRA, (2) reprocessing selected NPRA seismic lines to improve the interpretation of structural-stratigraphic relations, especially in the fold-and-thrust belt, (3) constructing a series of regional well-correlation sections in order to document North Slope stratigraphic sequences, and (4) documenting the Ellesmerian petroleum system.

A major portion of the USGS's North Slope effort during 1989 was devoted to producing summary reports for the Geological Society of America's Decade of North American Geology series. These reports include summaries of the geologic framework of northern Alaska (North Slope and Brooks Range)(Moore and others, 1990), the petroleum 


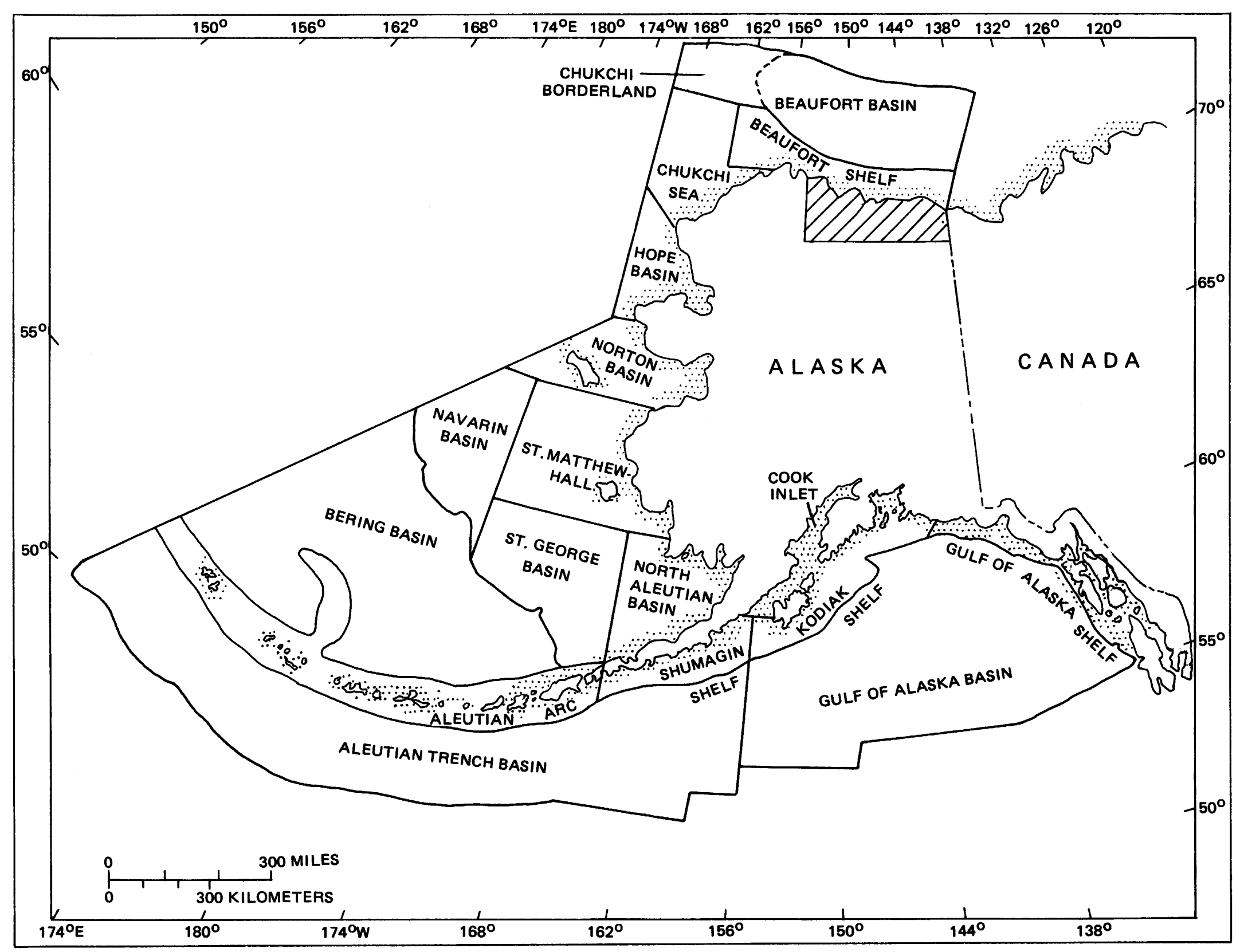

Figure 9. Offshore geologic province boundaries (dashed where approximately located) defined by MMS and USCS for national assessment; also shows location of 1989 joint MMS-State studies (lined area). 
geology of the North Slope province (Bird, 1990a), the petroleum geology of the State of Alaska (Magoon, 1990), and fossil-fuel resources of North America (Bird, 1989). An additional item in this series will be a multicolored map of Alaska and adjacent offshore areas showing sedimentary basins and oil and gas fields (scale 1:2,500,000). An earlier version of this map is currently available as USGS Miscellaneous Investigations Series Map I-1873 (Kirschner, 1988).

Interior Basins

During 1989, USGS scientists continued their work on the geology and petroleum potential of the interior basins of Alaska (those south of the North Slope as shown on fig. 5). A two-week field program focused on the detailed facies architecture of Tertiary fluvial and lacustrine deposits in the northern foothills of the Alaska Range. Preliminary results were presented in a poster session at the 1989 annual meeting of the American Association of Petroleum Geologists in San Antonio, Texas (Stanley and others, 1989).

The petroleum source potential of Mesozoic and Tertiary coals and mudrocks in the middle Tanana Basin is currently being evaluated using Rock-Eval pyrolysis and vitrinite reflectance. Preliminary results show an abundance of gas-prone kerogen and a wide range of thermal maturity related to depth of burial and nearness to igneous intrusions (Stanley, 1987, 1988).

\section{Cook Inlet}

Rock and oil samples from the Cook Inlet and Alaska Peninsula areas were analyzed to determine the origin of oil in the Cook Inlet basin. Biomarkers, carbon isotopes, and regional relationships indicate two different sources: oils in the upper Tertiary nonmarine reservoirs were derived from nonmarine source rocks, while oils from the lower Tertiary nonmarine reservoirs were derived from Middle Jurassic marine shales in the upper Cook Inlet area and from Upper Triassic and Middle Jurassic marine shales in the lower Cook Inlet-Alaska Peninsula area.

\section{Gas Hydrates}

Gas hydrates are naturally occurring solids composed of rigid "cages" of water molecules that entrap gases, mainly methane. USGS studies, funded in part by DOE, suggest that the depth interval in which these methane hydrates are stable is areally extensive beneath most of the North Slope coastal plain. Most North Slope gas hydrates, which are identified by well-log response, occur in six laterally continuous units of Upper Cretaceous and lower Tertiary sandstone and conglomerate; geographically, they are restricted to the area overlying the eastern part of the Kuparuk River and the western part of the Prudhoe Bay oil fields. Calculations suggest that the volume of gas within these mapped hydrates is approximately 8 to 10 trillion cubic feet. Recent drilling and geologic analysis of this area have revealed the presence of a free-gas domain at the base of the methanehydrate stability zone. Future work will focus on the relation between the gas hydrates and associated free-gas accumulations, and on a mechanism for reducing pressure in the hydrate reservoir, thereby causing hydrate decomposition and concurrent free-gas production.

\section{Thermal Maturity Map of Alaska}

For 12 years, geologists from the Branch of Petroleum Geology have been collecting thermal history data from across Alaska. These data include results of USGS studies as well as information released into the public domain by the petroleum industry. Les Magoon (USGS) and Link Materna (Petroleum Information Corporation) have assembled these data into the Petroleum Geochemical System, a data base that will soon facilitate search and retrieval by data type, location, age, or lithologic unit. In late 1989 , Mark Johnsson (USGS) began to compile the same data, which include measurements of vitrinite reflectance, RockEval pyrolysis, and thermal alteration index, into a thermal maturity map. The final map, which may actually take the form of a series of maps representing various time intervals, should prove valuable not only in the location of hydrocarbon resources in Alaska, but also for the interpretation of tectonic and basin development in a structurally complex part of the Earth's crust.

To date, thermal maturity data exist from some 10,000 samples representing more than 3,000 outcrop localities and 200 wells (fig. 10). Anita Harris (USGS) has provided conodont color alteration index data from some 1,500 localities throughout Alaska (Harris and others, 1987). Additional data will enhance control in parts of the state for which coverage is currently limited.

National Resource Assessment

As discussed in the MMS section above, the USGS and MMS recently completed a joint assessment of the Nation's undiscovered conventionally recoverable oil and natural gas resources (that is, those resources located outside of known oil and gas fields)(Mast and others, 1989). The methodologies employed were based on a probabilistic, geologic play-oriented approach. A geologic play is a group of geologically related prospects having similar hydrocarbon sources, reservoirs, and traps. For Alaska (onshore and State offshore), the total amount of conventional oil and gas remaining to be discovered as of January 1 , 1987, was estimated to be 13.2 billion barrels of oil, 57.9 trillion cubic feet of gas, and 1.6 billion barrels of natural gas liquids (mean values). Most of these resources are expected to be found on the North Slope. The range of estimated oil and gas resources for each of the 11 Alaskan 


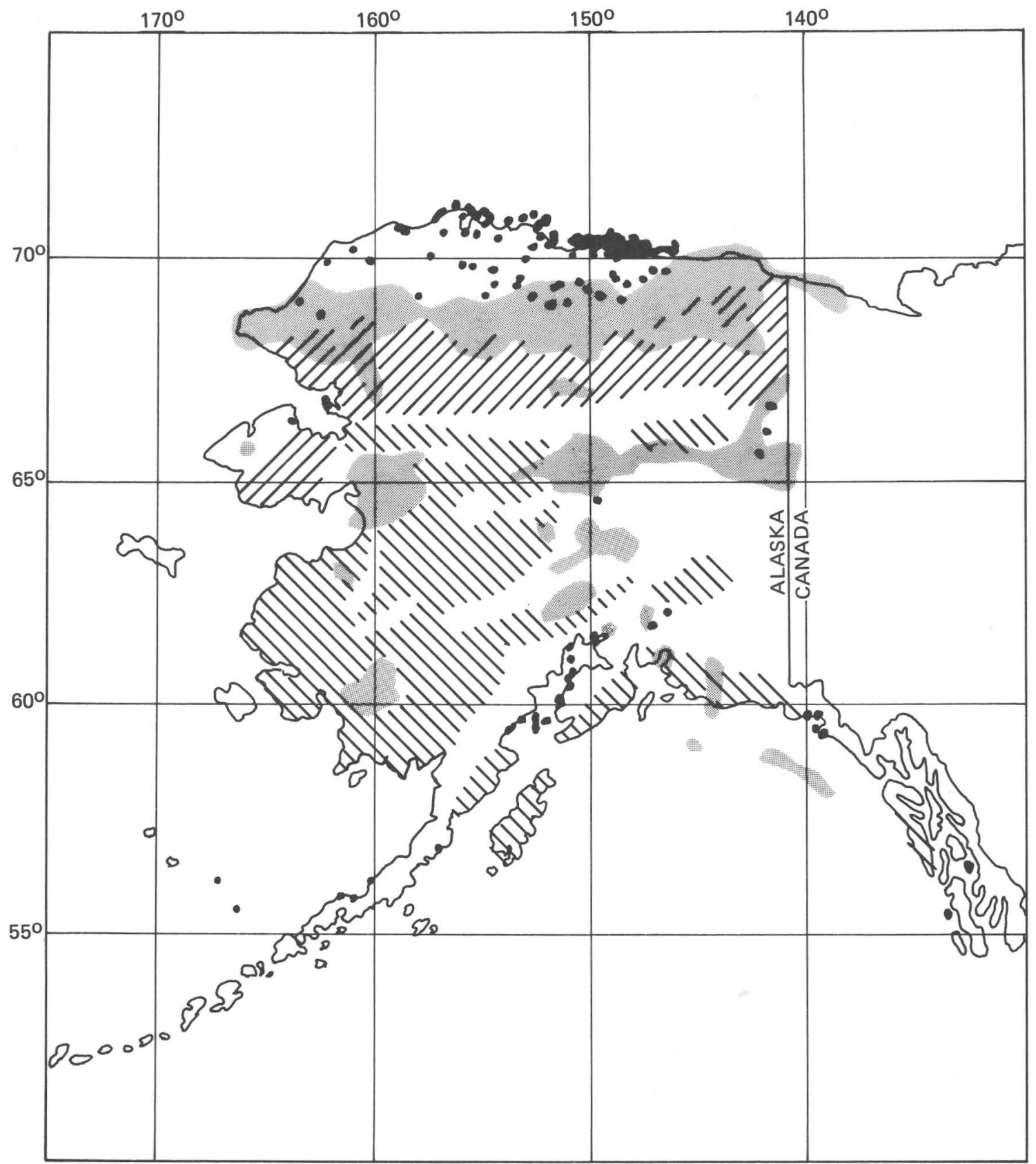

NOT AN EQUAL-AREA PROJECTION

EXPLANATION

Areas for which vitrinite reflectance or pyrolysis data exists

\section{Surface data}

$\because$ Subsurface data
P. Area of dense conodont color alteration index data (Harris and others 1987)

Area of poor sample coverage (January 1990)

Crystalline rocks or Holocene overburden

Figure 10. Thermal maturity data coverage for Alaska. 
Table 6. Reports summarizing petroleum geology and geologic plays in Alaska from the January 1, 1987, national resource assessment

\begin{tabular}{|c|c|c|}
\hline Province & Author & $\begin{array}{l}\text { USGS Open-File } \\
\text { Report }\end{array}$ \\
\hline \multicolumn{3}{|l|}{ North Slope } \\
\hline Arctic Coastal Plain & Bird & 90____ [in press] \\
\hline Northem Foothills & Bird & 90____ [in press] \\
\hline Southem Foothills & Bird & 90____ [in press] \\
\hline \multicolumn{3}{|l|}{ Central Alaska } \\
\hline Yukon-Kandik & Magoon and Kirschner & $88-450 \mathrm{~T}$ \\
\hline Alaska Interior ${ }^{1}$ & Magoon and Kirschner & $88-450 \mathrm{~T}$ \\
\hline Bristol basin & Magoon and Kirschner & $88-450 \mathrm{~T}$ \\
\hline Cook Inlet & Magoon and Kirschner & $88-450 \mathrm{~T}$ \\
\hline Alaska Peninsula & McLean & $87-450-\mathrm{H}$ \\
\hline Hope basin (onshore) & Fisher & $88-383$ \\
\hline Kodiak Island & Fisher & 88-385 \\
\hline Gulf of Alaska & Bruns & $88-450-\mathrm{J}$ \\
\hline Southeast Alaska & Bruns & $88-450-I$ \\
\hline
\end{tabular}

${ }^{1}$ Includes Bethel, Copper River, Holitna, Kobuk, Minchumina, Ruby-Rampart, Susitna, and Tanana basins.

provinces was described in USGS Circular 1040 (Schneider, 1989, p. 23-24). Descriptions of the geologic plays and the petroleum geology of each province are available in the USGS Open-File Reports listed in table 6.

\section{Bureau of Land Management}

Mineral resource assessments were completed in the Central Yukon, Fort Greeley, and Fort Wainwright planning areas, and are in the final stages for the South-central planning area. In addition, an energy and mineral resource assessment was started in the Western Arctic area (including NPRA). This study will include a detailed oil and gas study of the Utukok Special Management Area, a coal inventory of NPRA, and an analysis of the metallic mineral potential of southern NPRA.

The Branch of Mineral Assessment completed its synthesis of bedrock geology of the northern Rocky Mountain Cordillera at the Alaska-Yukon border. At least 10 areally extensive units of pre-Ellesmerian clastic carbonates were identified in outcrop. Drill-stem tests from wells immediately west of ANWR have produced oil and condensate from these units. Seismic data indicate that some of these same lithologies are present in ANWR. A report detailing this information will be published in 1990. Both the Branch of Mineral Assessment and the Branch of Lease Operations are presenting papers at the Fifth Circum-Pacific Energy and Mineral Conference in Honolulu, HI, in July 1990.

The annual report of the Branch of Pipeline Monitoring is available through the BLM Public Affairs Office located in the Federal Building in Anchorage. This branch, part of the Division of Mineral Resources, assures that the terms and conditions of Alyeska Pipeline Service Company's pipeline rights-of-way are met. The BLM's involvement with the Northwest Alaskan Pipeline Company's proposed Alaska Natural Gas Transport System (ANGTS) remains at a low level. On November 16, 1989, the DOE's Office of Fossil Fuels issued an export license to Yukon Pacific Corporation (YPC) for export of North Slope natural gas to Pacific Rim countries from YPC's Trans-Alaska Gas System (TAGS). The Branch of Pipeline Monitoring has begun the process of issuing temporary use permits for preliminary activities related to this project.

In establishing and implementing an oil and gas leasing program as required by Section 1008 of ANILCA, the BLM has made land available for noncompetitive oil and gas leasing in three areas south of latitude $68^{\circ} \mathrm{N}$. Both the Minchumina and the Denali-Tiekel-Slana areas were opened in 1982, the Seward Peninsula in 1983 (fig. 11). As of September 30, 1989, the BLM had 5,679 leases on 1,849,364 acres in these areas. On the Seward Peninsula, 147 leases on 406,766 acres were issued during 1989. These leases were the offers that had been suspended by preliminary injunction during the lawsuit National Wildlife Federation v Burford et $a l$. in 1985; this injunction was vacated on November 4, 1988. Except for NPRA and potentially ANWR, all BLMadministered oil and gas estates in Alaska are now handled under the leasing system established by the Federal Onshore Oil and Gas Leasing Reform Act of 1987.

Fish and Wildlife Service

The primary efforts of the FWS in Alaska are to protect and conserve fish and wildiife and their habitats and to administer 16 national wildlife refuges (fig. 4). The FWS also cooperates with other Federal and State agencies in similar efforts on behalf of wildlife throughout Alaska. Any oil- or gas-related activities in refuges are subject to FWS restrictions and protective stipulations.

\section{Kenai National Wildlife Refuge}

The Kenai National Wildlife Refuge is the only refuge in Alaska from which oil and gas have been produced. During 1989, between 26 and 30 wells were in production totaling 5,100 bbl/d at the Swanson River field (fig. 5). Workovers were conducted at several wells, and one shallow gas well was drilled to provide utility gas for field operations. Three wells were plugged and abandoned; others were shut-in due to poor oil-to-gas ratios or downhole problems. Field production to date represents 46-percent recovery of the estimated original oil in place. The Beaver Creek field (fig. 5) produced a maximum output of 34,000 million cubic feet per day (mcf/d) from three gas wells, and 550 $\mathrm{bbl} / \mathrm{d}$ from two oil wells. 


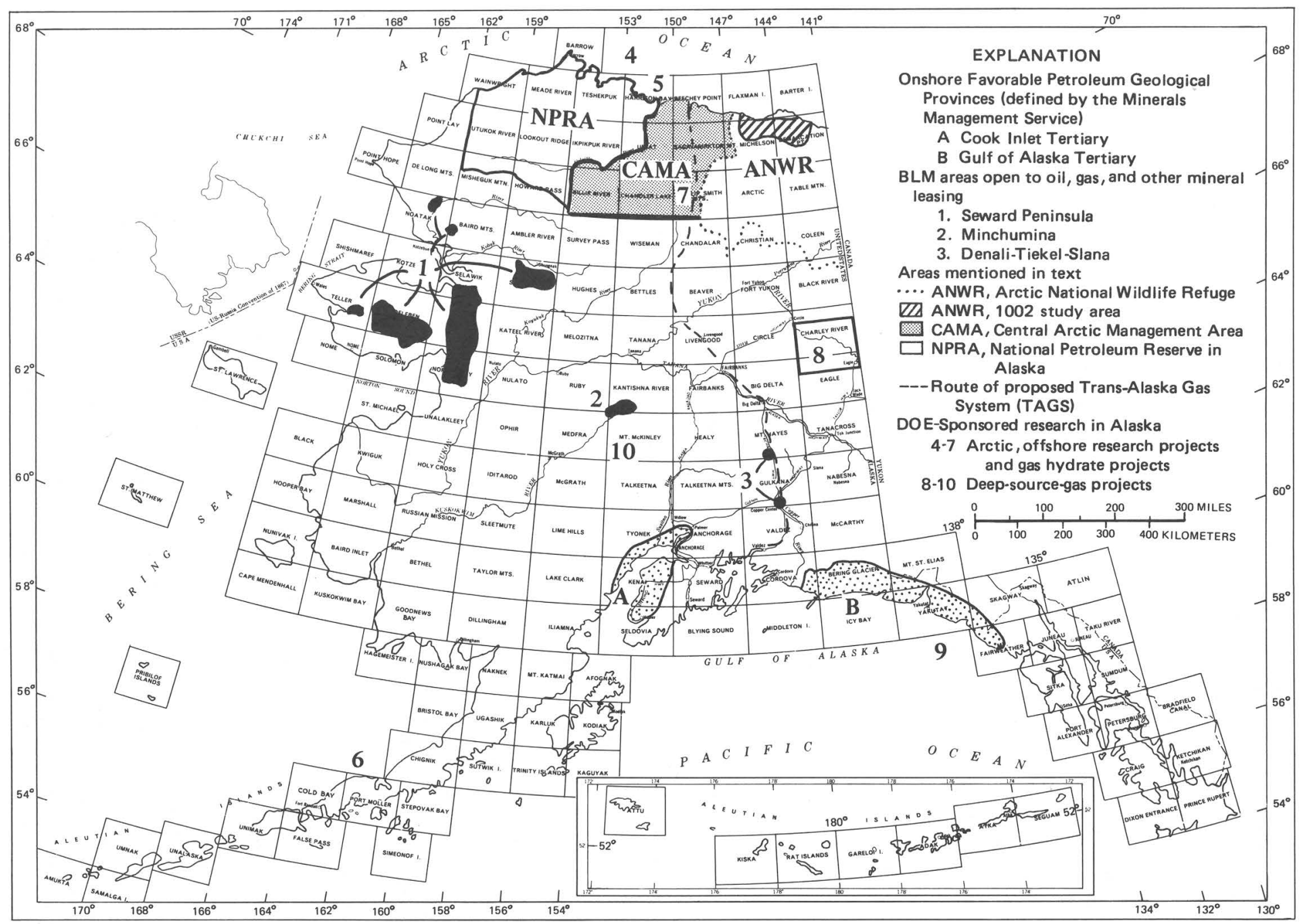

Figure 11. Onshore Favorable Petroleum Geological Provinces (land units referred to in text) and locations of DOE-funded research in 1989. 
The cleanup of soils contaminated with polychlorinated biphenyls (PCB's) within the Swanson River field has been accomplished with the exception of two limited areas to be completed next season. The on-site Circulating Bed Combustor unit, designed to destroy PCB's through a fluidized-bed incineration process, processed 22,828 tons of PCBcontaminated soils. Final processing of stockpiled contaminated materials should be attained by the fall of 1991 .

Activities under Section 1008 of ANILCA

Section 1008 of ANILCA provides for oil and gas studies on refuges in Alaska to gather information for use in future land-management decisions. In 1989, special-use permits were issued for surface geologic work in the Alaska Peninsula and Selawik National Wildlife Refuges. In the Kenai National Wildlife Refuge, two permits were issued for seismic exploration. Special-use permits include numerous stipulations for ensuring that permitted activities are environmentally sound, compatible with refuge purposes, and designed for the specific locale and activities of the proposal. Bonds of at least $\$ 10,000$ for surface geology studies, and $\$ 100,000$ for seismic studies, must be posted before any company can undertake such work in Alaska refuges. Copies of data resulting from permitted explora- tion must be submitted to the FWS; such data remain confidential in storage with the BLM.

Section 1008 of ANILCA also calls for establishing a program for oil and gas leasing on Federal lands south of latitude $68^{\circ} \mathrm{N}$., pursuant to the Mineral Leasing Act of 1920 as amended. All leasing, exploration, and production would be subject to permits and stipulations designed to protect fish, wildlife, and subsistence activities. This program does not apply to those refuge lands where the Secretary of the Interior determines, after consideration of the national interest, that oil and gas exploration or development would be incompatible with the purposes of the refuge. Section $304(\mathrm{~g})$ of ANILCA cites a comprehensive conservation planning process as the means for identifying parts of refuges where leasing or related activities may be compatible. Comprehensive Conservation Plans for all 16 national wildlife refuges in Alaska were completed by late 1988.

\section{Resource Activity Impact Assessment}

FWS resource-related activity includes making recommendations for mitigating adverse impacts on fish and wildlife and their habitats. To this end, the FWS reviews U.S. Army Corps of Engineers permit applications under Section 404 of the Clean Water Act of 1977; these applica-

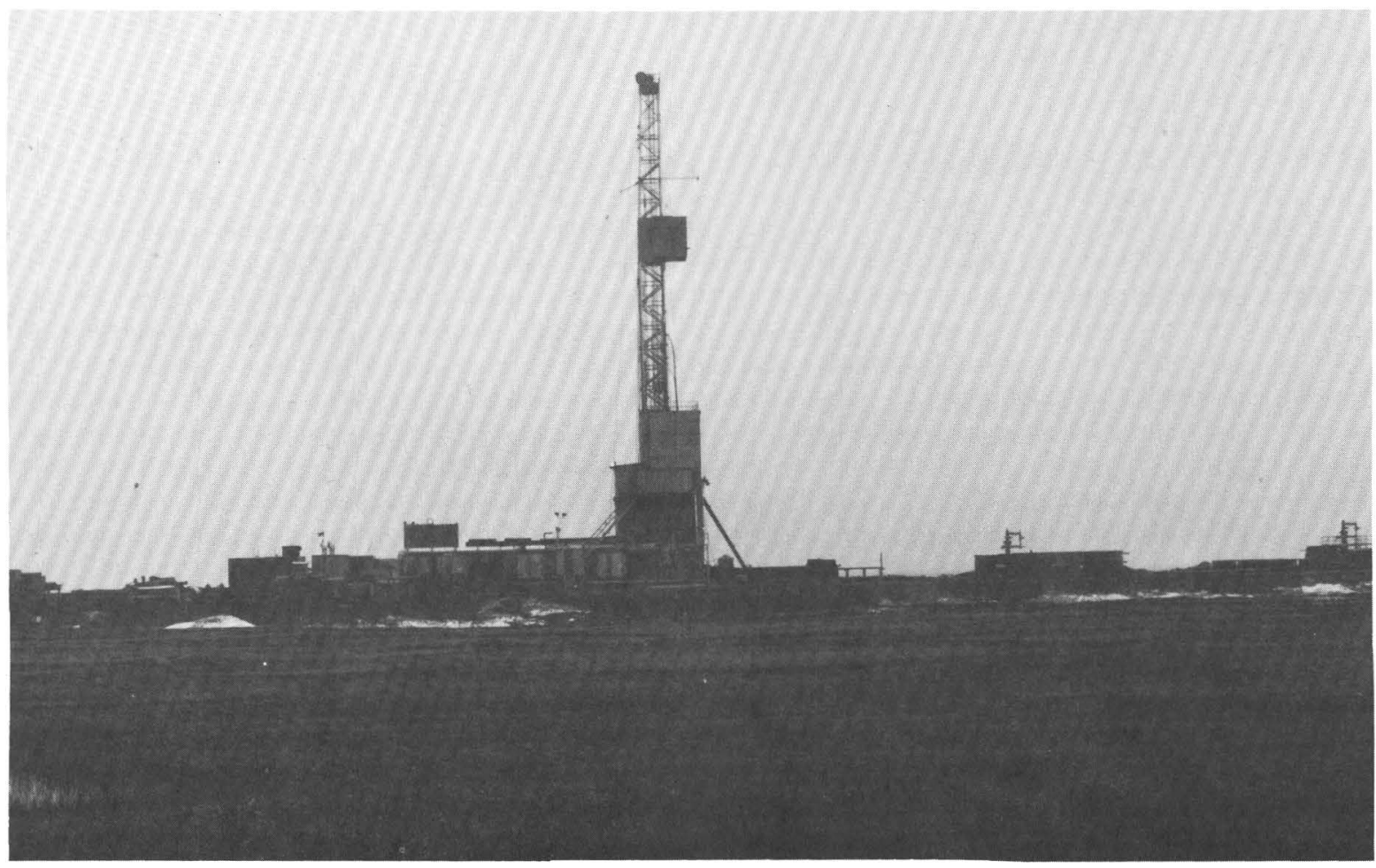

Figure 12. Drill rig at Prudhoe Bay on Alaska's North Slope. Six-foot-thick gravel pad replaces extant vegetative cover to insulate permafrost against seasonal temperature fluctuations. Photograph by $\mathrm{O}$. Ferrians. 
tions may involve public or private lands. The review includes recommendations for minimizing habitat losses in all proposals for new or modified roads, pads, well sitings, and operations (fig. 12). In 1989, the FWS reviewed and commented on 3 Federal OCS lease-sale EIS's and 32 Section-404 permit applications in the existing Prudhoe Bay, Kuparuk, and Endicott oil fields, the Barrow gas fields, and for exploratory wells throughout the North Slope.

\section{Department of Energy}

\section{Arctic Activities}

The Arctic and Offshore Research subprogram of the DOE's Advanced Extraction and Process Technology program was established to enhance petroleum-energy development by examining critical natural forces (such as sea ice and subsea-permafrost formation) and their effects, to develop technologies for utilizing Alaskan natural gas, and to establish a data base for Arctic parameters. Much of the subprogram's efforts are directed at offshore development (Morgantown Energy Technology Center, 1988); onshore objectives involve enhanced oil recovery, Alaska natural gas utilization, and the study of heavy oil, oil shale, and tar sands.

In 1989, DOE continued development of the Arctic energy-related technology data base (AORIS, detailed below), demonstrated AORIS at international conferences, coordinated interagency research, and studied the applicability of recovery techniques to Arctic petroleum occurrences.

The Arctic and Offshore Research Information System (AORIS) is a computerized (PC version) information service designed to assist the technological and planning community in the development of Arctic oil and gas resources. It has three principal components: a directory that lists 85 data bases containing Arctic energy-related information and how to access them; a bibliographic/management information system (B/MIS) containing over 8,000 references and abstracts on energy-related research; and a scientific and engineering information system containing over 800 quantitative data sets, in both tabular and graphic formats, on sea-ice characteristics from the B/MIS citations (Shoemaker and Chiang, 1988). AORIS also contains much unpublished information on the Arctic. After AORIS is completed in March 1990, it will be transferred to the public sector via the National Energy Software Center. The public may purchase AORIS (with appropriate use and data entry documentation) for use on their own computer systems and add to, update, or otherwise modify it for specific tasks; they may also make it available to others, if desired.

\section{Sea-Floor-Soils Research}

To improve Arctic petroleum-development technology, the DOE sponsored research on sea ice and sea-floor soils through several institutions and agencies. At the Uni- versity of Alaska, research was conducted on generation of ice islands from the Canadian Islands ice shelves and on their drift paths into the Alaskan Beaufort Sea. Several ice islands that have calved off the Ellesmere Island ice shelves during the past few years are being electronically tracked in hopes of developing a drift-simulation model. Most of these buoy-equipped ice islands are currently located off Ellef Ringnes Island, 650 miles west of Greenland, and are slowly proceeding southwest toward Alaska. Preliminary simulation of ice-island drift trajectories indicate that ice islands in the Arctic Ocean have a 10-year recurrence area along the Alaskan Beaufort Sea coast. This simulation study indicates that engineering designs in the Alaskan Beaufort Sea offshore areas need to include interactions with ice islands.

An assessment conducted by the Polar Research Board of the National Research Council identifies and evaluates the research needed during the remainder of this century to provide a better understanding of the solid-earth geophysical and geologic character of the Arctic, with an emphasis on the Arctic Ocean Basin and its perimeter. The board will identify the principal research questions in Arctic solid-earth sciences, recommend priorities to guide the direction of future research in this field, and indicate the facilities and support required for conducting meaningful research.

Research was conducted by Sandia National Laboratories, in cooperation with DOE and MMS, on measuring acceleration and velocity responses of the sea-floor soils to strong earthquakes. In 1986, a redesigned Seafloor Earthquake Measurement System (SEMS-II) unit, deployed in 250 feet of water near Shell's Ellen-Elly platforms about 10 miles west of Long Beach, California, monitored two southern California earthquakes. Preliminary analysis of the data collected by SEMS-II indicates that there is a significant difference between the vertical and horizontal accelerations at the seabed site of SEMS-II and that the horizontal accelerations are almost an order of magnitude larger than the vertical; at land-based sites, the horizontal and vertical accelerations are similar. Further analysis and research may reveal other significant differences. Progress toward developing reliable soil-loading models from earthquake data will depend on collecting additional data from both seabed sites and nearby offshore platforms for earthquakes large enough to cause significant motion of the platforms. The SEMS-II unit was retrieved in December 1987 to correct a datacollection triggering problem. Sandia deployed the redesigned unit (SEMS-III) near the Shell platforms in July 1989. Deployment of a second SEMS-III is planned for the summer of 1990, approximately 5 miles off Point Arguello, California, in about 250 feet of water.

\section{Petroleum Research}

A primary petroleum target is the gas-hydrate reservoir, which contains gas in a solid, icelike form. Occurrences of such hydrates have been identified on Alaska's 
North Slope, and the technology for characterizing and developing this resource is under study as part of the DOE's Environmental and Advanced Research subprogram. Using both inhouse and contractors' facilities, subprogram efforts have recently been concentrating on laboratory testing of natural and synthetic hydrates to define the pressure and temperature conditions necessary for their formation and dissociation, as well as the geophysical and mechanical properties of the hydrates and their reservoirs (Morgantown Energy Technology Center, 1987a). Arctic research studies to determine in-place conditions of gas-hydrate deposits have been initiated by DOE in cooperation with the USGS and with Arco Alaska, BP Alaska, Exxon, and Conoco. As part of the research on gas hydrates, geologic basin reports have been published for a number of offshore areas in a series titled "Geological evolution and analysis of confirmed or suspected gas hydrate localities." Volume 12 is "Basin analysis, formation, and stability of gas hydrates in the Beaufort Sea" (Krason and Finley, 1989). This series of studies is being conducted by Geoexplorer International.

The DOE's research on deep-source gas is focused on evaluating the potential for recovering gas from depths greater than 30,000 feet, based on the hypothesis that natural gas could be generated in sediments carried to these depths by tectonic processes. Primary reservoir targets are former and active subduction zones where suitable sediments have been encapsulated. Recent study areas (fig. 11) include the Yukon Flats near Fairbanks, the Alaska Range of south-central Alaska, and the eastern Aleutian Trench, where cooperative stratigraphic, structural, and magnetotelluric studies have taken place (Morgantown Energy Technology Center, 1987b).

\section{Arctic National Wildlife Refuge}

With the enactment of ANILCA in 1980, the Arctic National Wildlife Range in northeastern Alaska was enlarged to 18.6 million acres and renamed the Arctic National Wildlife Refuge (ANWR). Approximately 8 million acres of ANWR was designated wilderness, to be managed under terms of the Wilderness Act (78 Stat. 892). Subsequently, other land additions have increased the size of the refuge to about 19.5 million acres. Section 1002 of ANILCA pertains to an approximately 1.5 -million-acre strip of the coastal plain of ANWR, now known as the 1002 area (fig. 11). Section 1002 requires the Secretary of the Interior to (1) conduct a comprehensive, continuing baseline study of the fish and wildlife resources of the 1002 area, (2) develop guidelines to initiate and monitor an oil and gas exploration program, and (3) prepare a report to Congress describing the fish, wildlife, and hydrocarbon resources; the potential impacts and development scenario for petroleum exploration and production; and recommendations as to whether exploration, development, and production for oil and gas should be allowed in the 1002 area.
The FWS was designated as principal coordinator for the Section 1002 resource assessment, and that agency, the BLM, and the USGS prepared an interagency memorandum of understanding in 1983 for the research and writing of the 1002 report for Congress. The specific agency roles and research are described in the "1987 Annual report on Alaska's mineral resources" (Bohn, 1987, p. 20-24) and in the report to Congress (Clough and others, 1987). During 1989, Alaska Federal agency activity regarding the 1002 area focused on responding to political and public inquiries regarding the final 1002 report findings and continuing the research and study program.

\section{Fish and Wildlife Service}

In 1989, the FWS continued to respond to congressional inquiries concerning the potential for oil and gas leasing and development on the ANWR coastal plain. On March 16, the Senate Energy and Natural Resources Committee reported a bill that would authorize oil and gas leasing on the coastal plain. This and other 1002-related bills included numerous protective stipulations for the fish and wildlife resources of the area. The bill did not receive floor action.

Recognizing that a variety of regulatory and planning processes would immediately be initiated if legislation is passed to open the coastal plain to oil and gas activities, FWS continues to pursue a biological study program on the area. The goal of this program is directed at achieving a better understanding of the area's natural dynamics, altered ecosystem dynamics that might result from oil and gas activities, associated adverse impacts, and the means by which to avoid, minimize, or rectify those adverse impacts.

The " 1002 Work Group," composed of BLM and FWS representatives, met in early 1989 to review and update management issues and processes necessary for the pursuit of an orderly oil and gas program on the 1002 area.

The DOI's legislative environmental impact statement on the acquisition of selected inholdings in national wildlife refuges in Alaska was made available on December 16,1988 . Under the preferred alternative, six exchange participants involving 18 Native corporations would acquire limited oil and gas interests underlying approximately 166,000 acres on the ANWR coastal plain in exchange for approximately 896,000 acres of inholdings in seven refuges in Alaska. The Record of Decision recommending that Congress adopt the proposed exchanges was signed by the Secretary of the Interior on January 19, 1989. Congress may consider this recommendation and supporting documents as they continue deliberations on the larger question of opening ANWR to oil and gas development.

\section{Exxon Valdez Oil Spill}

The March 24, 1989, grounding of the 987-footlong T/V Exxon Valdez on Bligh Reef in Prince William 
Sound (fig. 13) resulted in the largest oil spill in U.S. history. More than 11 million gallons $(262,000$ barrels) of Prudhoe Bay crude oil spilled into eastern Prince William Sound, then moved southwest along the shores of the Kenai Peninsula. Three days after the spill, high winds grounded the planes that were to deploy chemical dispersants on the slick. Subsequent containment efforts by the Alyeska Pipeline Service Company, Exxon, and the USCG could not halt the spread of oil and the ensuing pollution of beach and marine habitat. Shorelines in the Kenai Fjords National Park and Alaska Maritime National Wildlife Refuge were heavily oiled (fig. 14). Caught in the Alaska Current, oil swept down the Shelikof Strait and washed ashore on beaches of both the Alaska Peninsula and the Kodiak Archipelago, affecting parts of the Alaska Peninsula, Becharof, and Kodiak National Wildlife Refuges, Katmai National Park and Preserve, and Aniakchak National Monument and Preserve.

By summer's end, the outer limits of the spill spanned a distance roughly equivalent to the stretch of coastline from Maine to North Carolina; more than 3,000 miles of shoreline and intertidal habitat had been oiled. In addition, more than 1,000 dead sea otters and 36,000 dead birds had been collected.

Exxon began full cleanup operations in late April. Using high-pressure hoses, oil was flushed from affected beaches back into the water and picked up by skimmer boats. Large boulders and rocky shorelines were handscrubbed with absorbent materials. Work was suspended in mid-September for safety reasons: winter weather in Prince William Sound made boat operation extremely hazardous. By year's end, Exxon had spent $\$ 1.2$ billion to treat 1,089 miles of beaches (Alaska Report, May 9, 1990).

\section{Bureau of Land Management}

As a first response to the Exxon Valdez crisis, the BLM's Pipeline Monitoring staff conducted an immediate review of oil-spill-contingency equipment and supplies inplace along TAPS. The Alyeska Pipeline Company promptly complied with BLM's request to replace any supplies, such as chemicals and absorbent materials, used in the initial spill response.

At the request of the NPS, BLM sent an Incident Command team to Seward to assess the situation there. The team gathered detailed information on the spill area and directed the coordination, dispatch, and tracking of aircraft, boats, equipment, manpower, and fuel for the cleanup. With the NPS, the team also established a multi-agency coordination group for all parties on the Kenai Peninsula affected by the spill. This was the first time that BLM had used its Incident Command System for situations other than firefighting; the system was well received by Seward residents and officials. During the second week of spill response activity, the Alaska Department of Emergency Services re- quested BLM's assistance in setting up a similar interagency team at Valdez.

BLM provided staffing assistance to handle public inquiries at DOI's Office of Environmental Project Review in Anchorage and to the regional response team center in Valdez. BLM's Alaska Fire Service maintained a 24-hour command headquarters to provide ground and air transportation and information officers. BLM also provided and set up four remote weather stations in the Prince William Sound area and on the Kenai Peninsula to track weather conditions affecting the oil spill's movement. Finally, BLM contributed a myriad of supplies and equipment to facilitate the massive interagency cleanup effort.

\section{Fish and Wildlife Service}

On-scene participation by the FWS in response to the spill was twofold: (1) support for the USCG Federal on-scene coordinator and (2) response to effects on FWS trustee resources-refuge lands and waters, cultural resources found on these lands, raptors and other migratory birds, and sea otters.

In the early days of the spill, FWS concentrated its efforts on documenting the numbers, species, and locations of migratory birds and the numbers and locations of sea otters in the spill area and in areas that potentially could be affected. The FWS also provided resource information to the USCG, conducted beached wildlife and habitat surveys, established wildlife receiving stations, and supervised wildlife rescue and rehabilitation.

Through interagency committees in Valdez, Seward, Homer, and Kodiak, FWS participated heavily in shoreline cleanup operations by planning and monitoring shoreline cleanup activities, conducting shoreline surveys for prioritizing beaches for cleanup, and evaluating the use of bioremediation and dispersants. Particular attention was given to affected national wildlife refuge lands. In the refuges, 624 miles of coastline was identified for cleanup: Alaska Maritime Refuge, 275 miles (34 miles moderate to heavy oil deposits, 241 miles very light to light); Alaska Peninsula/ Becharof Refuge, 144 miles (17 miles moderate to heavy, 127 miles very light to light); and Kodiak Refuge, 205 miles (18 miles moderate to heavy, 187 miles very light to light).

The FWS is deeply involved in the planning and implementation of the Natural Resource Damage Assessment Plan being coordinated among the several trustee agencies. The FWS portion of the assessment concentrates on its trustee responsibilities for migratory birds, sea otters, and refuge lands.

\section{Minerals Management Service}

While MMS had no direct responsibility for oil spill response or damage assessment, the agency participated in meetings with State and other agencies involved in monitoring the spill and the study of its effects, including field 


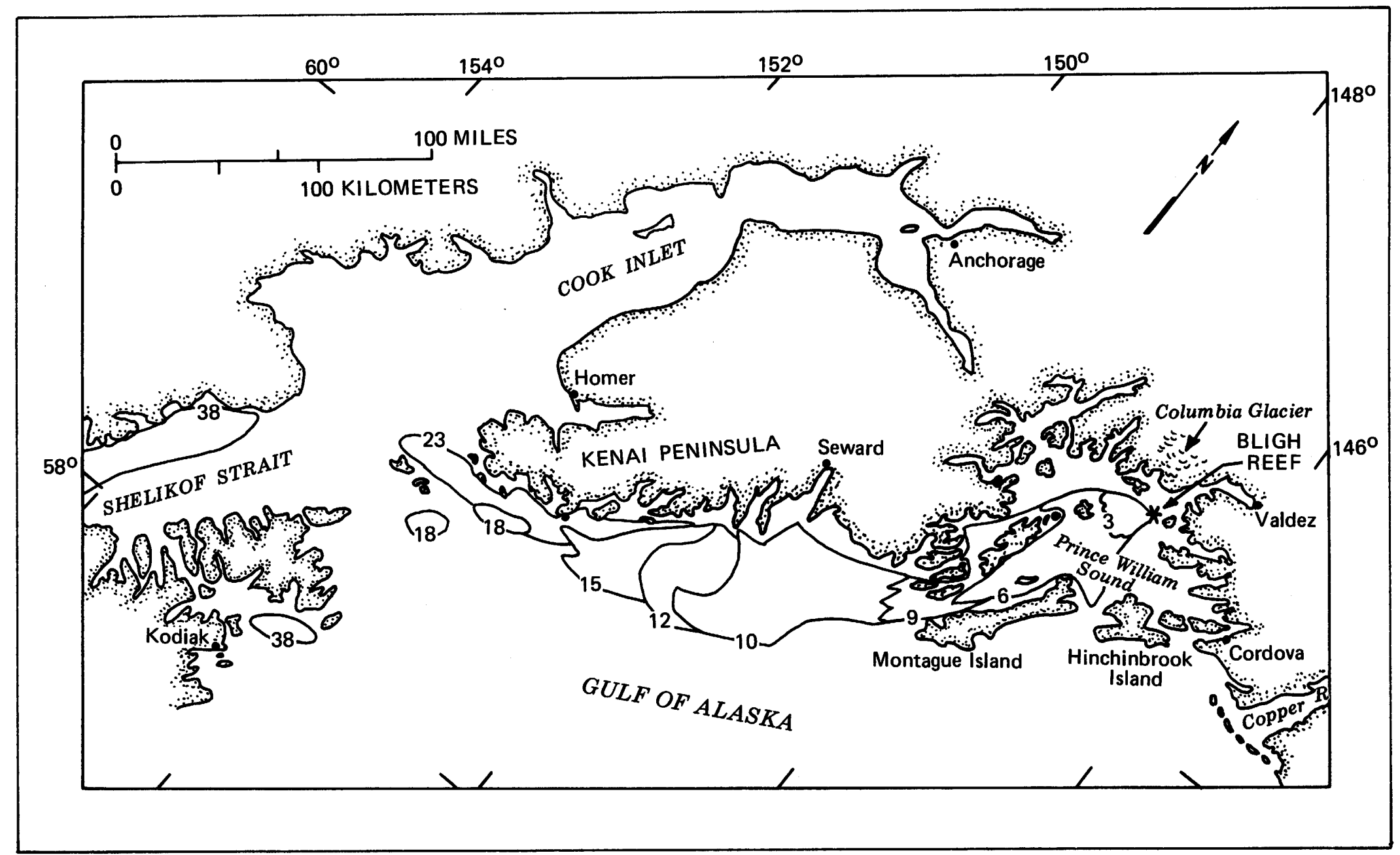

Figure 13. Northern Gulf of Alaska showing site of TN Exxon Valdez grounding on Bligh Reef on March 24, 1989, and resultant oil spill. Numbered lines indicate leading edge and days elapsed (modified from Carlson and Reimnitz, 1990). 
treatment operations and the protection of resources. In addition, MMS provided more than $\$ 250,000$ for assessment studies and for staff to assist in the cleanup. Funded studies included weathering of crude oil in seawater and the development of an oil-weathering model; the effects of oil on different species of fish and crustaceans, and their sensitivity to oil at different stages in their life cycles; chemical analysis of sediment to determine the presence of oil; and the social impact of the spill on Native and non-Native communities affected by the spill. Financial support was also provided for coastal and aerial surveys of sea otters and seabirds and for the purchase of radio tags for tracking sea otters. The MMS/NOAA research vessel \#1273 was provided for use as a field sampling platform. Funds were provided to the USGS for sediment collection using the GLORIA survey ship M/V Farnella. Finally, MMS funds were also provided to monitor the performance of satellite-tracked surface oil drifters and for overflights of the spill itself.

\section{National Park Service}

Driven by wind and ocean currents, the oil struck three park units: Kenai Fjords National Park, Katmai Na- tional Park and Preserve, and Aniakchak National Monument and Preserve. A fourth park unit, Lake Clark National Park and Preserve, is still thought to be at risk from the spill, but oil has yet to be found on its shores.

The NPS was involved in the full range of oil spill activities relating to the Exxon Valdez oil spill. Responding to the imminent threat of oil striking shorelines of park units on the Gulf of Alaska and the Alaska Peninsula, NPS activated an Incident Command team to assist in the mobilization, management, and coordination of responses to the spill. Incident Command Centers were established in Seward and Kodiak; logistical support offices were located in Homer and Kenai. Overall incident management was provided by an Area Command Office in Anchorage.

The NPS was instrumental in establishing the MultiAgency Coordination Group in Seward and the Kodiak Interagency Shoreline Cleanup Committee in Kodiak. These groups provided a clearinghouse for spill response-related issues within their respective zones. The NPS reviewed numerous unusual activities and issued Special Use Permits to allow their execution. These included establishment of fuel caches, helicopter landings, oil and wildlife monitoring by various State and Federal agencies, placement of remote

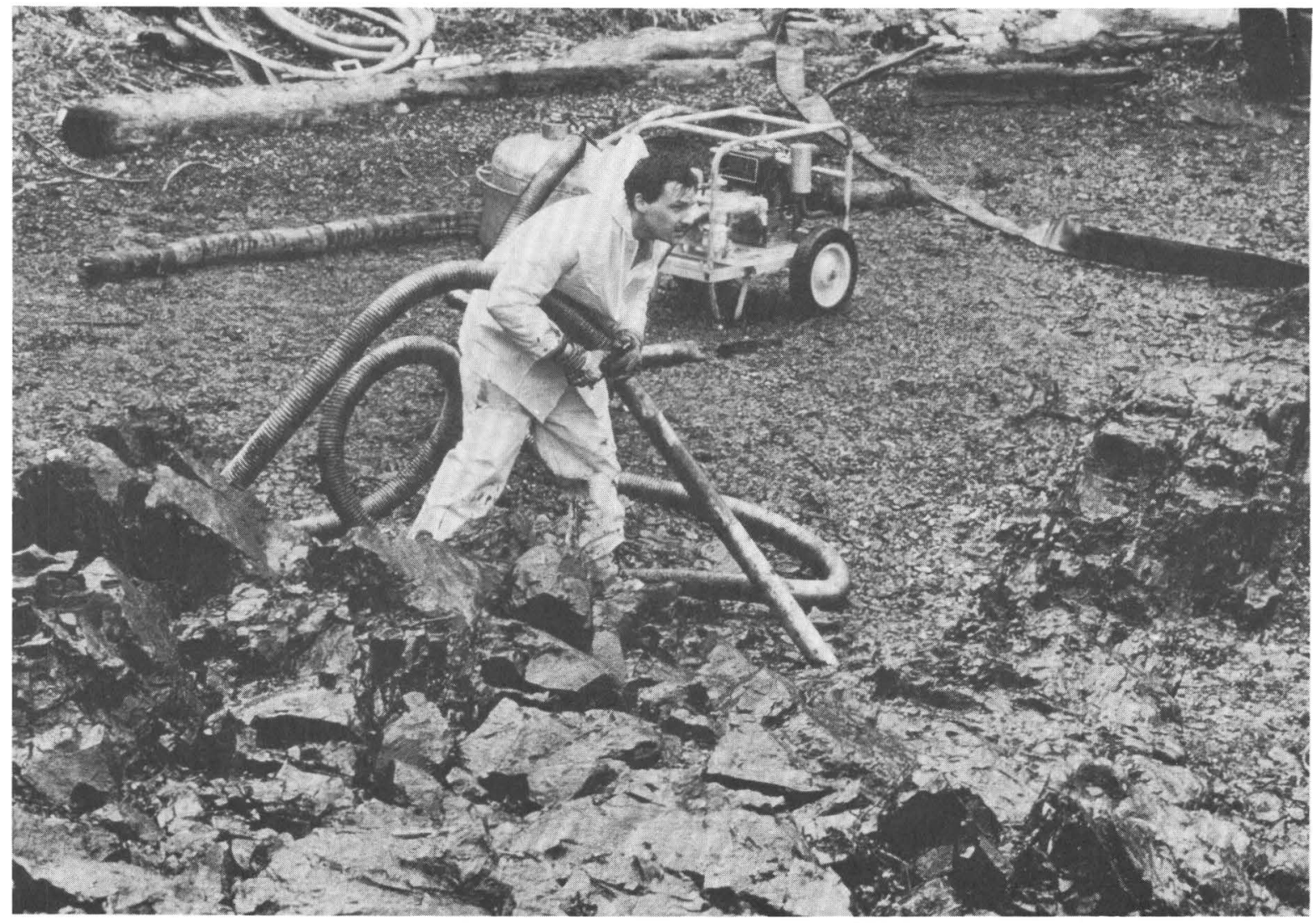

Figure 14. Cleanup operation on oiled beach, Prince William Sound. Photograph by J. Bauermeister. 
weather stations, and cleanup activities of various types. The NPS also assisted in development of the damage assessment and restoration plan, cooperated with damage assessment studies, and participated as a DOI representative to the damage assessment management team.

Park rangers and resource managers from the NPS accompanied the various cleanup and monitoring crews working along park shorelines. These people conducted shoreline and wildlife surveys, documented locations of contaminated zones, prioritized shorelines requiring treatment, suggested reasonable and appropriate treatment methods, monitored shoreline treatment, and provided wildlife protection to cleanup crews. Personnel and logistical support were also provided to the FWS, USCG, State agencies, and Exxon.

When shoreline activities diminished with the onset of winter, NPS demobilized its Incident Command structure and established an Office of Oil Spill Coordination in the Alaska Regional Office, Anchorage. The office participates in interagency oil spill activities, provides oversight of spill-related programs for the affected park units, fulfills trust responsibilities in the damage assessment and restoration process, and develops plans for the 1990 field season.

\section{U.S. Geological Survey}

In response to the Exxon Valdez oil spill in Prince William Sound, the USGS modified its scheduled work in the Gulf of Alaska to include a 4-day cruise in mid-May for sampling seafloor sediments along the spill trajectory (fig. 13). Funding for this cruise was provided by MMS and USGS. Twenty stations were selected for box coring, focusing on present-day sediment sinks in the Prince William Sound region near the most severely polluted surface areas. Analytical procedures were designed to determine sedimentation rates in the sinks and to detect hydrocarbons related to the spill.

The results of the cruise and laboratory analyses are discussed in USGS Open-File Report 90-39 (Carlson and Reimnitz, 1990), a collection of 6 papers by 10 investigators analyzing sediment deposition, hydrocarbons, radionuclides, and possible effects on benthic organisms. The USGS will implement a program in 1990 to monitor both deepand shallow-water sediments to determine the fate of the spilled oil as a parameter in the sedimentation history of the Sound and the Gulf.

\section{U.S. Forest Service}

Since 80 percent of the coastline in Prince William Sound is in the Chugach National Forest, the USFS became involved very early in the oil spill recovery process. Its immediate role was to identify specific sites for radio relays, boat and aircraft refueling, and weather stations used by the emergency response crews. Of particular concern to the USFS was the protection of biological, archaeological, and recreational resources near the shoreline. USFS resource specialists were integral members of the interagency Resource Advisory Teams, which monitored and advised the Exxon work crews. These advisory teams helped interpret policy for specific conditions and resource problems dealing with salmon spawning, seal pupping areas, and archaeological sites.

A prime goal of the cleanup effort was to hold to a minimum the impact of the hundreds of workers and the variety of techniques used. Archaeological sites of both Natives and settlers which could have been unwittingly destroyed or damaged by cleanup activities were identified, and special precautions taken. One such precaution by the USFS was to direct that crews be housed on ships or barges to minimize their impact.

Six months of hard work involved over 12,000 workers, scientists, and managers, 2,000 vessels, 95 aircraft, and 128,000 feet of containment and absorbent boom materials. Exxon spent over $\$ 1$ billion in this cleanup and resource protection effort. Although the majority of oil has not been recovered, the free, mobile oil on the surface of the water and shore has been generally removed. Many of the shores and cliffs, however, still have a tough layer of weathered, tacky oil on the surface of the rock faces. In addition, oil found beneath the beach surface has proved difficult to remove.

It is important to remember that of about 3,500 miles of shoreline within Prince William Sound, only about 1,500 miles in the western half of the sound was in danger from floating oil, and only about 300 to 400 miles of shoreline was actually oiled. Islands in the northwestern corner of the sound were impacted first and most heavily by the oil. Visitors who see the sound from cruise ships are not likely to encounter any oil.

\section{Coal and Peat Resources}

"Alaska is the heart of our long-term future for coal," said Richard L. Lawson, president of the National Coal Association (Anchorage Times, November 30, 1989). "Alaska's huge reserves remain virtually untapped, and many of the State's coal fields are near tidewater, making Alaskan coal important for future export to the emerging Pacific Rim marketplace." Such optimism for the future of coal production in Alaska has been high for several years. Fueling this optimism were two years of record coal production in 1987 and 1988. At the Usibelli coal mine, Alaska's only active producer, output for 1989 was 1.45 million short tons, down 6 percent from 1988's record of 1.55 million short tons (Bundtzen and others, 1990). This small decrease was due largely to the timing of coal ships leaving Seward rather than any real decrease in production at the mine in Healy. 
During 1989, industry activity was focused on two Alaskan coal fields: Matanuska Valley and Healy (fig. 15). Development continues at the Wishbone Hill coal project near Palmer in the Matanuska Valley. The coal is highquality bituminous coal with low moisture and sulfur contents. Idemitsu Kosan, a Japanese petroleum company, plans a truck-and-shovel open-pit mine that could produce up to 1 million short tons per year and employ 180 people. The coal will be trucked to a railyard near Palmer, loaded into railcars, and then transported to Seward to be loaded onto ships bound for Japan. Alaska has earmarked State funds for road improvements between the mine site and Palmer (Anchorage Times, January 18, 1989). Road improvements should be completed by 1990 or 1991 to meet Idemitsu Kosan's development schedule.

Usibelli Coal Mines Incorporated has signed documents extending their contract to export coal to South Korea (Anchorage Daily News, January 11, 1989). This contract calls for an annual shipment of 880,000 short tons from the mine in Healy, with a latitude of 20 percent in the volume of coal shipped.

Peat mined in Alaska is used primarily in agriculture and greenhouses as a soil conditioner; minor amounts are burned locally in villages for heat. Peat production decreased in 1989 to 51,000 cubic yards, down 4,000 cubic yards from 1988 (Bundtzen and others, 1990).

\section{Activity by Federal Agencies}

\section{U.S. Geological Survey}

USGS personnel have been investigating the depositional environments of the Tertiary fluvial deposits of the Nenana coal field. Stanley and others (1989) reported that the coal-bearing Healy Creek Formation was deposited by migrating braided streams on a surface with a few hundred meters of relief. Within the formation, the coarse clastic rocks represent stacked, high-energy fluvial channels, and the mudstones reflect quiet water deposition in abandoned channels.

Branch of Coal Geology personnel continue to investigate the major-, minor-, and trace-element distribution at the Usibelli coal mine near Healy. In 1989, 50 coal samples in two face channels were collected for chemical analysis. Previous work here has indicated that many of the trace elements vary both horizontally and vertically within the three coal beds being mined. The subbituminous coals at Healy have some of the lowest reported sulfur values for any coal presently being mined in the United States (mean of 0.24 percent and range of 0.1 to 1.5 percent total sulfur)(Affolter and Stricker, 1987).

Investigations at a scale of 1:250,000 were begun on coals in the Seldovia quadrangle (fig. 15); studies in 1989 were confined to the Jurassic coals near the town of Seldovia. Vitrinite reflectance in oil indicates that these deformed coals are semianthracite in rank. Future work is planned for the Tertiary coals around and north of Homer.
Geochemical studies have been completed for the Tertiary coals of the Sagavanirktok Formation in the eastcentral part of the North Slope. The next phase for investigation of these low-sulfur coals (mean of 0.37 percent and range of 0.08 to 2.02 percent total sulfur) will be the evaluation of their resource potential. Preliminary estimates indicate a hypothetical resource in excess of 200 billion short tons (Roberts and others, 1990).

\section{U.S. Bureau of Mines}

The USBM Twin Cities Research Center in Minnesota granted funds to the University of Alaska's Palmer Research Center to study the use of mycorrhizal fungi in stimulating revegetation on abandoned coal mine lands. Woody plants, such as alder and poplar, were treated with the fungi and transplanted to a site near Sutton, where their growth will be monitored (Vieth and others, 1989). Coal mining research is also funded at the University of Alaska-Fairbanks through the USBM Mineral Institute program.

\section{Bureau of Land Management}

The BLM continued its management of a lease in the Jarvis Creek coal field south of Delta Junction (fig. 15). Coal from this field is a potential feed stock for gas production, which would be used to generate electrical power for the U.S. Army base at Fort Greeley and the U.S. Air Force backscatter-radar installation near Glenallen. Interest in additional coal leasing on Federal land is currently growing.

\section{Fish and Wildlife Service}

The FWS commented on the early plans for the Wishbone Hill coal project near Palmer and made technical recommendations to mitigate possible fish and wildlife habitat losses.

\section{Department of Energy}

The Healy Cogeneration Project was awarded a $\$ 93.2$ million grant from the Department of Energy for use in the construction of a state-of-the-art mine-mouth power plant at the Usibelli coal mine. This was one of 13 grants awarded nationwide under the Federal Clean Coal Technology Program (Bundtzen and others, 1990).

\section{Uranium Resources}

The last uranium mined in Alaska came from the Ross-Adams ore body in the peralkaline granite at Bokan Mountain (fig. 15), where 1.3 million pounds (lbs) of 


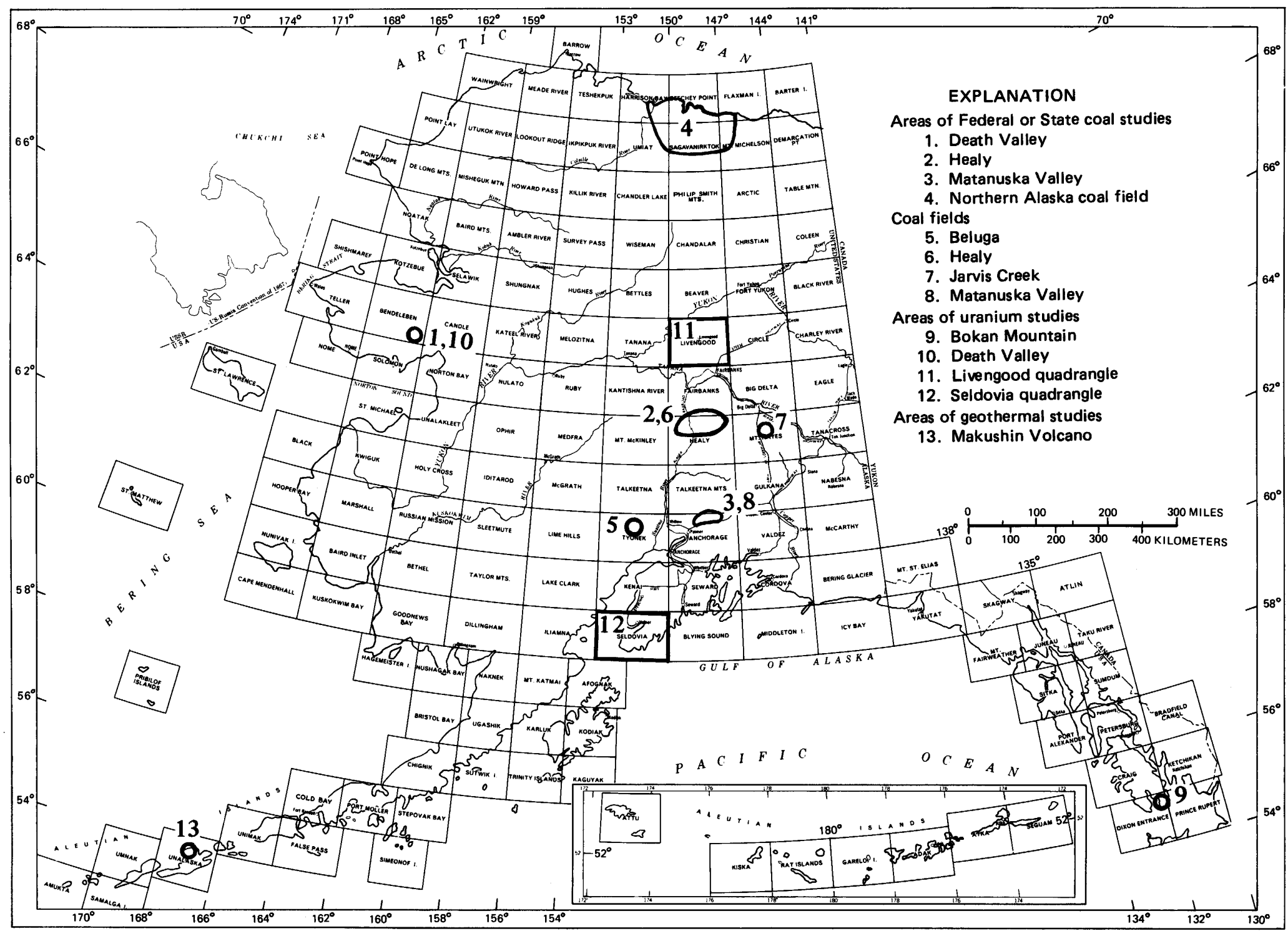

Figure 15. Areas of potential coal and peat, uranium, and geothermal resources mentioned in text. 1:250,000-scale quadrangles are outlined and labeled. 
uranium oxide $\left(\mathrm{U}_{3} \mathrm{O}_{8}\right)$ was produced during the period 1957 1971 (Warner and Barker, 1989). Since that time, the lack of known large deposits, the high costs of exploration and development, and the low spot prices for $\mathrm{U}_{3} \mathrm{O}_{8}$ have prevented the exploitation of Alaska's uranium resources.

There is potential, however, for commercial-size uranium deposits in Alaska, especially in its Tertiary basins. One such deposit was discovered in 1980 in the Tertiary sandstones at Death Valley on the Seward Peninsula (fig. 15). Development of the Death Valley deposit and further exploration around the State have been greatly hampered by the extensive Quaternary glacial and other deposits that blanket much of Alaska.

\section{Activity by Federal Agencies}

U.S. Geological Survey

A core program in uranium research continues to be carried out by the USGS in the Branch of Sedimentary Processes. Due to a lack of funding for fieldwork, no new geologic data pertaining to uranium resources are presently being acquired from Alaska.

Three recent reports describe a thorium-uranium deposit at Roy Creek, about 18 miles west of Mount Prindle in the Livengood B-1 quadrangle (fig. 15) (McCammon and others, 1988; Weber and others, 1988; Armbrustmacher, 1989). The undiscovered thorium endowment for this area is calculated at 7,000 tons of thorium oxide $\left(\mathrm{Th}_{2} \mathrm{O}\right)$. Data are insufficient to make a similar calculation for uranium, but values as high as 1.9 percent $\mathrm{U}_{3} \mathrm{O}_{8}$ and 18.2 percent $\mathrm{Th}_{2} \mathrm{O}$ are reported (McCammon and others, 1988).

\section{Geothermal Resources}

Hot springs occur throughout Alaska and historically have been used on a small, highly localized scale for recreation, space heating, and agriculture. However, with widespread young volcanic activity on the Aleutian Islands, the Alaska Peninsula, the Wrangell Mountains, and elsewhere in the State, the potential exists for geothermal energy production to serve many population centers.

Both DOE and the Alaska Power Authority have investigated the practicality of developing a geothermal production facility at Makushin Volcano (fig. 15) for the neighboring communities of Dutch Harbor and Unalaska, centers of a burgeoning fishing industry. Test well results show that the volcanic system is capable of generating enough electricity to meet the power needs of these two towns for decades. In exchange for mineral exploration privileges, Battle Mountain Exploration is continuing geothermal investigations at Makushin for the Aleut Native Corporation.

No Federal research was funded for geothermal studies in 1989.

\section{NONFUEL-MINERAL RESOURCES}

\section{Metallic Minerals}

\section{Industry Activity}

Mineral exploration and production in Alaska continued to expand for the third consecutive year. Exploration expenditures rose to $\$ 47.8$ million (Bundtzen and others, 1990 ), and the total value of mineral production rose to \$277 million, a 19-percent increase over 1988 levels (table 7). However, development expenditures dropped significantly, down 51 percent to $\$ 134.3$ million. This decrease reflects the shift from development phase to production modes at both the Greens Creek and Red Dog projects. The shift toward production was probably also responsible for the reduction in number of people employed in the mining industry, down 4 percent to 4,179 in 1989. Therefore, the total value of Alaska's mineral industry, defined by the sum of mineral production and exploration and development expenditures, declined overall to $\$ 459$ million in 1989 , down 17 percent from the all-time high of $\$ 552.6$ million in 1988 .

Gold maintained its status as principal ore commodity, accounting for 39 percent of the total dollar value of metallic-minerals production (table 7). An estimated 284,617 ounces (oz) was produced and valued at $\$ 108.7$ million. This represents an increase of 7 percent by volume, but a 4 percent decrease by value due to lower bullion prices, over 1988 levels. Metallic minerals accounted for 63 percent, industrial minerals for 22 percent, and coal and peat for 15 percent, by value, of the reported mineral production in Alaska for 1989.

The increase in 1989 gold production reflects output from both new and existing placer and hardrock lode mines. The Valdez Creek Mining Company placer operation east of Cantwell produced $61,403 \mathrm{oz}$ gold and was Alaska's largest gold producer in 1989. WestGold Incorporated recovered 30,661 oz placer gold from its offshore dredging operations at Nome. Another 169,023 oz gold came from the approximately 210 small gold placer operations around the State and from lode deposits on Ester Dome near Fairbanks.

The largest boost in metals production came from the Greens Creek mine on Admiralty Island in southeast Alaska. Shipping its initial ores in May 1989, the mine produced the first significant amounts of silver $(5,166,591$ oz), lead (9,585 short tons), and zinc (19,843 short tons) in Alaska, totaling $\$ 73.2$ million. Gold $(23,530 \mathrm{oz})$ was also produced at the mine (Bundtzen and others, 1990).

Gold and tin production are expected to fall in 1990. Although profitable in early 1989, the Valdez Creek mine was closed in October due to low gold prices. The mine will reopen when gold prices recover. Also, the Lost River Mining Company on the Seward Peninsula exhausted its tin-placer reserves in late 1989 and dismantled its operation there. 
Table 7. Mining production in Alaska, 1986-1989

[Values calculated from 1989 annual price averages of gold, silver, and platinum; other values directly supplied by mine operators. Data from Bundtzen and others (1990). NR, no report; W, information withheld by mine operators]

\begin{tabular}{|c|c|c|c|c|c|c|c|c|}
\hline & \multicolumn{4}{|c|}{ Volume } & \multicolumn{4}{|c|}{ Value $(x \$ 1,000)$} \\
\hline & 1986 & 1987 & 1988 & 1989 & 1986 & 1987 & 1988 & 1989 \\
\hline Gold (troy oz) & 160,000 & 229,700 & 265,500 & 284,617 & 60,800 & 104,516 & 112,837 & 108,724 \\
\hline Platinum (oz) & W & $\mathbf{W}$ & 25 & $\mathbf{W}$ & $\mathbf{W}$ & $\mathbf{W}$ & 14 & W \\
\hline Lead (tons) & NR & NR & NR & 9,585 & NR & NR & NR & 7,672 \\
\hline Zinc (tons) & NR & NR & NR & 19,843 & NR & NR & NR & 29,383 \\
\hline Tungsten (tons) & 120 & 160 & 240 & NR & 23 & 11 & 14 & NR \\
\hline Mercury (lb) & 912 & NR & $\mathbf{W}$ & W & 3 & NR & W & $\mathbf{W}$ \\
\hline \multicolumn{9}{|l|}{ Sand and gravel } \\
\hline (million tons) & 20.9 & 16.7 & 17.2 & 14.4 & 75,761 & 42,660 & 48,750 & 39,875 \\
\hline \multicolumn{9}{|l|}{ Building stone } \\
\hline Peat $\left(y d^{3}\right)$ & 50,000 & 46,000 & 55,000 & 51,000 & 350 & 299 & 375 & 352 \\
\hline Totals --.......... & -....-.-.-. & (.................... & (-)- & - & 198,393 & 202,390 & 232,172 & 276,984 \\
\hline
\end{tabular}

Exploration activities in Alaska increased slightly in 1989 , and expenditures totaled $\$ 47.5$ million, an increase of 5 percent over 1988. This is in contrast to northwestern Canada and Western United States, where mineral exploration generally declined (Bundtzen and others, 1990). As in previous years, the primary focus of exploration programs was precious metals. Almost 92 percent of all expenditures were for precious-metal exploration; expenditures for basemetal and coal exploration totaled 6 percent and 2 percent, respectively. Three major lode-gold exploration projects, the Fort Knox project near Fairbanks and the Kensington and Alaska-Juneau (A-J) projects in southeastern Alaska, accounted for 59 percent of all exploration expenditures.

In western Alaska, the Bering Straits Native Corporation and Svzal, a Soviet mining firm, have formed a joint venture to develop mineral deposits in both Alaska and the Soviet Union (Anchorage Times, January 15, 1990). The State of Alaska also conducted a lottery for 19 offshore gold leases in the Nome area. Conditions of the lottery require that gold exploration be conducted on the tracts.

In response to the U.S. Supreme Court and Alaska State Supreme Court rulings that the extraction of mineral resources without rents or royalties paid to the State of Alaska violates the Alaska Statehood Act, the Alaska Legislature adopted a system of rents and royalties, effective August 31,1989 . Annual rents would range from $\$ 20$ per claim in the first 5 years to $\$ 100$ per claim for those held 11 years or longer. Similarly, mining leases would range from $\$ 0.50$ per acre to $\$ 2.50$ per acre depending on the age of the lease. Royalty regulations will seek 3 percent of net profits from operating mines (Anchorage Times, November 22, 1989).

In May 1989, Federal injunctions halting placer mining were lifted for the Birch Creek and Fortymile River watersheds near Fairbanks (Alaska Journal of Commerce and Pacific Rim Reporter, June 5, 1989). The Alaska Department of Environmental Conservation adopted new mixing-zone water quality regulations in 1988 that were to help placer miners and other industrial water users comply with the State's turbidity standards (Green and Bundtzen, 1989). Guidelines were developed to allow the new regulations to be tested in 1989 and implemented in the 1990 season. However, the Federal Environmental Protection Agency (EPA) imposed stringent effluent guidelines in 1989 requiring 100-percent recycling of mine process waters for the placer mining industry. These regulations and accompanying land reclamation laws necessitated extensive mine-plan revisions, resulting in lower average bullion output by small placer-mining companies statewide (Bundtzen and others, 1990).

The Ninth Circuit Court of Appeals upheld a Federal District Court decision that affirmed the right of miners to operate within Alaska's National Parks before validity testing has been conducted by the NPS (Anchorage Times, April 17, 1989).

The 11th Annual Alaskan Conference on Placer Mining was held March 29-April 1 in Fairbanks. Program topics focused on reclamation, new technology for placer mining, the future of placer mining, and geology of mineral deposits (Fairbanks Daily News-Miner, March 24, 1989). 
The Alaska Miners Association and the Alaska Minerals and Energy Resource Education Foundation sponsored "Conference Juneau," a two-day symposium in Juneau, April 19-20. This conference focused on exploration, mining projects, and mineral research in southeastern Alaska, westem British Columbia, and the Yukon.

The 14th Annual Convention and Trade Fair of the Alaska Miners Association was held October 31-November 4, in Anchorage. The focal point of the convention was the Agency Session, in which representatives of the major Federal and State agencies presented an overview of their activities. Other major topics discussed were the effects of conservation legislation on the State, the importance of the mining industry on regional and local economies, the geology and mining of placer deposits, and current developments and new discoveries of hardrock mineral deposits (Alaska Miner, October 1989).

The University of Alaska-Fairbanks hosted the First International Symposium on Mining in the Arctic in July 1989. The conference was attended by mining leaders from seven nations. Topics of discussion included increased recovery from underground placer mines in permafrost, the techniques of mining in harsh conditions, and reduction of the environmental impact of mining (Alaska Journal of Commerce and Pacific Rim Reporter, August 7, 1989).

Nerco Minerals presented a grant for $\$ 198,614$ to the University of Alaska-Fairbanks Mineral Industry Research Laboratory. The grant is to fund research on hydrometallurgy of complex sulfide ores. Successful hydrometallurgical treatment of sulfide ores would allow recovery of elemental sulfur and significantly reduce the pollutants generated by smelting techniques (Fairbanks Daily News-Miner, October 23, 1989).

\section{Precious Metals}

As of 1988, Alaska ranked sixth in the Nation in gold production with 265,000 oz harvested (Fairbanks Daily News-Miner, November 14, 1989); that amount increased in 1989 to 284,617 oz gold. Exploration and mining feasibility studies continued at a number of known lode gold mines and new deposits shown on figure 16.

The Greens Creek deposit on Admiralty Island was discovered in the early 1970's on the edge of the Admiralty Island National Monument. After completion of initial development, the first ore was shipped in May 1989, and the mine officially opened in September 1989. Some of the problems encountered during start-up included unanticipated secondary explosions caused by high concentrations of combustible dust (Anchorage Times, June 6, 1989), a 3,000gallon diesel-fuel spill (Anchorage Daily News, June 4, 1989), and high levels of pollutants in wastewater discharge (Anchorage Daily News, November 4, 1989). By September 1989, the level of all pollutants except cyanide had been reduced to acceptable levels. The level of cyanide discharge has since been significantly reduced, and is expected to meet EPA standards soon (Anchorage Daily News, December 15, 1989). At full production, the mine will yield about 1,000 tons of ore per day over a 10-year mine life and will be the nation's largest silver producer. Reserves are estimated at 3.5 million tons containing 24 ounces per ton (oz/t) silver, $0.18 \mathrm{oz} / \mathrm{t}$ gold, 9.7 percent zinc, and 3.9 percent lead (Anchorage Times, February 1, 1989).

RTZ Corporation, London, bought BP Minerals' 53.1 percent interest in the Greens Creek mine for $\$ 4.3$ billion (Anchorage Daily News, January 4, 1989). RTZ has resurrected the Kennecott Corporation as a wholly owned subsidiary to conduct its mining operations (Northern Miner, July 31,1989 ). Other owners of the Greens Creek operation include Hecla Mining (28 percent), CSX Corporation (12.6 percent), and Exalas Resources (6.3 percent). The mine employs about 220 workers, who commute daily via highspeed ferry from Juneau. The City and Borough of Juneau have initiated proceedings to annex the Greens Creek mine (Anchorage Daily News, June 7, 1989).

Extensive exploration programs continued at the Alaska Juneau (A-J) gold mine near Juneau. The A-J mine historically produced about 3.5 million oz gold, 1.9 million oz silver, and 40.2 million lbs lead from 1897 to 1944 (Berg, 1984). Since 1985, exploration and development has been conducted by Echo Bay Exploration and WGM Incorporated. Echo Bay is in the process of getting the necessary permits to begin development work at the mine. Reserves are projected at more than 100 million tons containing 0.047 $\mathrm{oz} / \mathrm{t}$ gold. The mine would have a 12- to 13-year life and employ about 450 people (Juneau Empire, February 22, 1989). The mine is owned by the City and Borough of Juneau and Alaska Electric Light and Power.

The Kensington mine, located in the Berners Bay area about 45 miles north of Juneau, is being evaluated in a joint venture by Echo Bay Exploration and Coeur d'Alene Mines. The mine is estimated to contain over 7 million tons of ore containing $0.15 \mathrm{oz} / \mathrm{t}$ gold. A 5,200-foot-long adit driven below the old Kensington adit intersected a zone 70 to 100 feet wide averaging 0.184 to $0.250 \mathrm{oz} / \mathrm{t}$ gold (Northern Miner, May 15, 1989).

The Jualin mine, about 3 miles southeast of the Kensington mine, is being evaluated by Curator International Resources and Placer Dome Incorporated. Exploration has been concentrated on the 1,000-foot-long, 600 -foot-wide Jualin shear zone. Reserves have been estimated at more than 1 million tons containing $0.309 \mathrm{oz} / \mathrm{t}$ gold. Placer Dome has agreed to spend \$7 million on exploration at the Jualin mine during the next 3 years (Northern Miner, July 17, 1989).

Alaska Apollo Gold Mines Limited and Ballatar Exploration have signed an agreement for development work at the Shumagin gold-silver mine on Unga Island. The mine has reported reserves of 278,000 tons containing $0.524 \mathrm{oz} / \mathrm{t}$ gold and $2.47 \mathrm{oz} / \mathrm{t}$ silver (Northern Miner, March 27, 1989). 


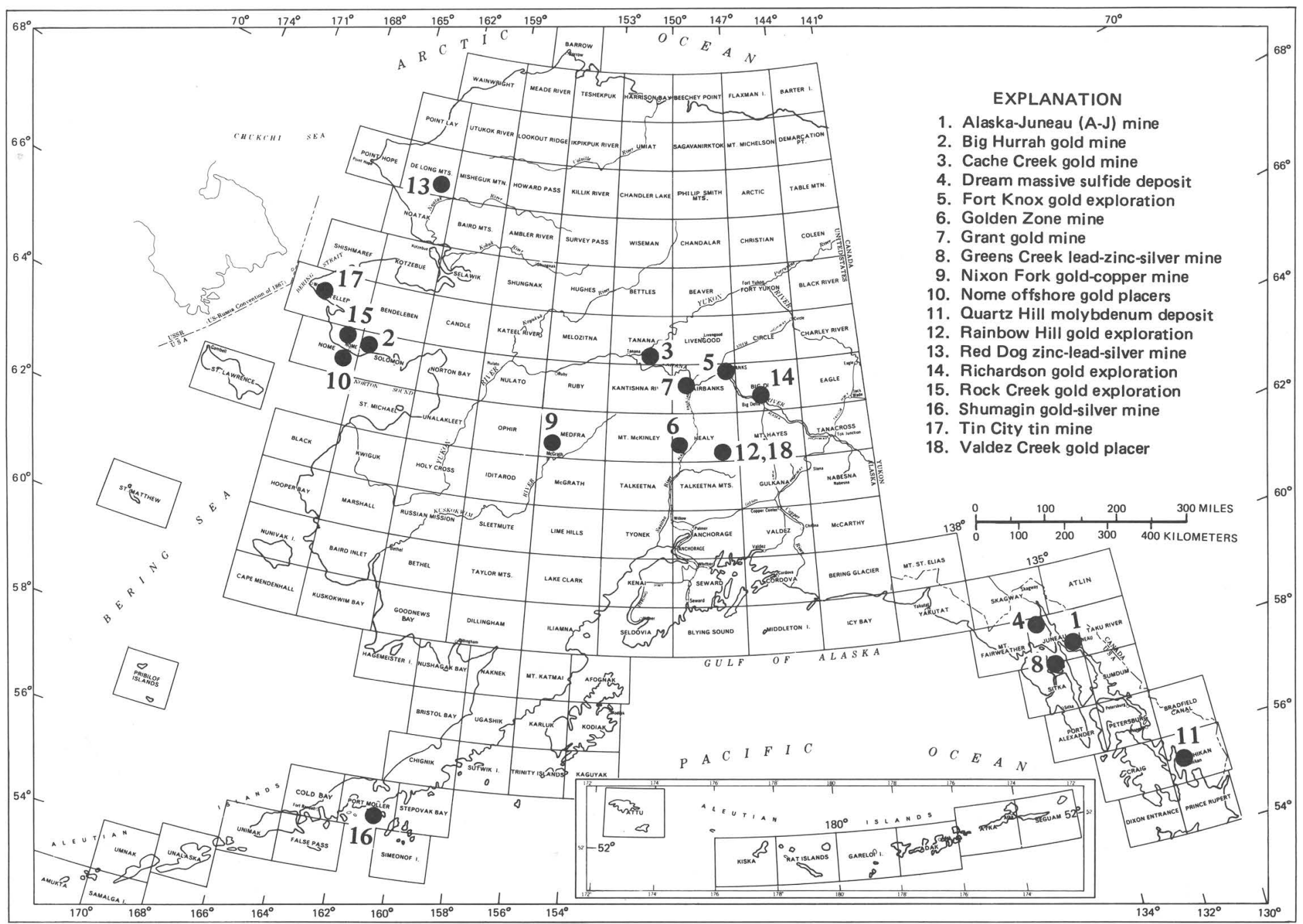

Figure 16. Areas of significant industry activity involving metallic minerals (excluding uranium) in 1989, with mine and deposit locations referred to in text. 1:250,000-scale quadrangles are outlined and labeled. 
The Valdez Creek mine, 80 miles east of Cantwell, is the largest active placer mine in Alaska. It produced $61,403 \mathrm{oz}$ gold in 1989 , up from $44,470 \mathrm{oz}$ in 1988 (Northern Miner, January 15, 1990). An agreement between Valdez Creek Mining Company and Aspen Exploration Corporation for the mining of ore on adjoining claims is expected to triple the mine reserves (Anchorage Times, April $5,1989)$. Total reserves held by the two companies are estimated at about $627,000 \mathrm{oz}$ gold. Operations were halted for the last three months of 1989 due to weak gold prices. However, if gold prices continue to rise as they did at the end of 1989 and in early 1990, then the Valdez Creek mine could be expected to reopen in the spring of 1990 (Northern Miner, January 15, 1990). The Valdez Creek mine is owned by Camindex Mines ( 51 percent), Cambior Incorporated (26 percent), and American Barrick Resources (23 percent) (Northern Miner, July 3, 1989).

Caprock Corporation announced a gold discovery in Roosevelt Creek, near the Valdez Creek mine. The deposit is in a paleochannel 8,000 feet long with grades of $0.107 \mathrm{oz}$ gold per cubic yard (Northern Miner, October 30, 1989).

Canalaska Resources reported high-grade gold intercepts in drill holes on its Rainbow Hill lode deposit in the Valdez Creek mining district. Intercepts were reported for 40 feet of $0.322 \mathrm{oz} / \mathrm{t}$ gold containing 15 feet of $0.811 \mathrm{oz} / \mathrm{t}$ gold, and another 40 feet of $0.210 \mathrm{oz} / \mathrm{t}$ gold containing 15 feet of $0.486 \mathrm{oz} / \mathrm{t}$ gold (Northern Miner, November 20, 1989).

United Pacific Gold withdrew from development and exploration work at the Golden Zone mine near Cantwell. Subsequently, Golden Zone Resources entered into a joint venture with Placer Dome whereby Placer Dome will do exploration and development work on the Golden Zone mine over the next six years. Golden Zone Resources estimates mine reserves at more than 500,000 tons containing 0.238 oz/t gold (Northern Miner, October 2, 1989).

Fairbanks Gold Limited conducted exploration drilling on the Fort Knox gold property near Fairbanks. Results of its 2-year drilling program show a potential for approximately 15 million to 30 million tons containing $0.06 \mathrm{oz} / \mathrm{t}$ gold (Northern Miner, May 15, 1989). Mineralization extends at least 1,000 feet below surface level, and the 6,000foot-wide mineralized zone is still undefined on all sides. More extensive drilling operations are planned for 1990.

Silverado Mines Limited operates the Grant mine at Ester Dome near Fairbanks. Negotions were under way in 1989 to establish a joint venture with Amax Gold (Northern Miner, May 1, 1989).

Tri-Valley Corporation continued evaluation of gold resources on its Richardson lode project, about 70 miles southeast of Fairbanks. It reported a potential for several million tons of reserves containing $0.09 \mathrm{oz} / \mathrm{t}$ gold. Empire Sand and Gravel was awarded a contract to mine and process up to 1 million tons of ore per year (Northern Miner, June 12, 1989).
Shoreham Resources Limited announced $25,610 \mathrm{oz}$ probable gold reserves and 40,000 oz possible gold reserves at the Cache Creek placer mine in the Tofty District. The company estimates a recovery of $2,300 \mathrm{oz}$ gold and 184,300 oz cassiterite from 26,000 cubic yards of gravel.

Caithness/Alaska Mining is a joint venture between Caithness Gold Mining and Palomar Capital. Caithness/ Alaska has an exclusive 7-year option for minerals exploration on 3.5 million acres held by Doyon Limited, an Alaskan Native regional corporation. Major targets identified thus far are the Flume Creek and Indian Mountain areas. Another joint venture between Caithness, Palomar, and Battle Mountain Exploration is evaluation of the Nixon Fork deposit near McGrath. The Nixon Fork deposit is reported to have 320,000 tons of reserves containing $1.105 \mathrm{oz} / \mathrm{t}$ gold (Northern Miner, September 4, 1989).

On the Seward Peninsula, Placer Dome and Aspen Exploration continued lode-gold exploration activities at the Rock Creek deposit near Nome. They reported reserves of about 470,000 oz gold (Anchorage Times, March 23, 1989). Forty miles east of Nome, exploration continued at the Big Hurrah mine. Valhalla Gold Group and Golden Zone Resources reported reserves of 400,000 tons of ore grading $0.296 \mathrm{oz} / \mathrm{t}$ gold (Northern Miner, April 17, 1989).

Southwest of Nome, the world's largest offshore gold dredge, the Bima, continues to extract gold from sea-floor gravel. The dredge recovered about 30,661 oz gold in 1989, down from the 1988 level of $35,500 \mathrm{oz}$ due to mechanical difficulties early in the season. WestGold Incorporated, owners of the Bima, own the mineral rights to 15 miles of sea bottom west of Nome, from the coast out to the Alaska 3-mile limit (Fairbanks Daily News-Miner, March 26, 1988). The company has recovered more than 100,000 oz gold since dredging began in 1985 .

The State of Alaska conducted a lottery to award 19 offshore tracts for gold exploration in the Nome area. There were 861 applications for the 19 lease tracts. Winners are required to spend at least $\$ 3$ per acre each year to maintain their leases.

\section{Other Metals}

Exploration studies and related activities for other metals occurred at various sites within Alaska in 1989; these are also shown on figure 16.

In the western Brooks Range, 90 miles north of Kotzebue, the Red Dog zinc-lead-silver deposit began producing zinc concentrates in late 1989 and is expected to produce 440,000 tons for shipment in late 1990 (Bundtzen and others, 1990). Red Dog will be the Western world's largest base-metals mine, employing about 300 workers. Reserves are estimated to contain 85 million tons of ore grading 17 percent zinc, 5 percent lead, and $2.4 \mathrm{oz} / \mathrm{t}$ silver (Nokleberg and others, 1987). Projected operating life of the mine is at least 50 years (Anchorage Times, October 31, 
1988). The ore will be extracted by open-pit mining, trucked west along a 52-mile haul road, and stockpiled at a shallow-water port on the Chukchi Sea northwest of Kotzebue. More than 2 million tons of ore will be processed annually, producing 580,000 tons of zinc concentrate, 120,000 tons of lead concentrate, and 50,000 tons of middling product (Alaska Journal of Commerce and Pacific Rim Reporter, July 18, 1988). The Red Dog mine is a joint venture between Cominco Alaska and NANA Regional Corporation. Development costs for the mine thus far have totaled about $\$ 450$ million (Anchorage Times, November 17, 1989).

International Curator Resources and Placer Dome U.S. agreed to joint exploration on the Dream massive sulfide prospect in the Chilkat Mountains, about 20 miles south of Haines. The property comprises three distinct mineralized zones in the same stratigraphic position along a strike length of 3 miles (Northern Miner, June 12, 1989).

On the Seward Peninsula, the Lost River Mining Company's operation at Tin City had been the largest primary tin mine in the United States, producing $180,000 \mathrm{lbs}$ tin in 1989, 150,000 lbs in 1988, and 280,000 lbs in 1987. However, ore reserves were finally exhausted, and operations were dismantled in late 1989 (Bundtzen and others, 1990).

\section{Activity by Federal Agencies}

\section{U.S. Geological Survey}

Studies of nonfuel minerals in Alaska are an important part of USGS programs. The Alaska Mineral Resource Assessment Program (AMRAP) continues to be the major USGS program for geologic mapping, mineral resource assessment, and specialized geologic studies of Alaska lands. Due to budgetary restraints, AMRAP activities in 1989 remained at the low 1988 levels. Site-specific studies on precious-metal and strategic and critical mineral deposits continued. Project work formally began on the comparative studies of ophiolites and of the metallogenesis of lode mineral deposits in the USSR Far East and Alaska. In addition, memoranda of understanding were signed between the USGS and the USSR Ministry of Geology and between the US National Science Foundation and the USSR Academy of Sciences. Geologists for the TACT program successfully completed geologic mapping and companion geophysical studies north of Wiseman on the southern flank of the Brooks Range. Locations of 1989 studies are included on figures 17 and 18.

Alaska Mineral Resource Assessment Program

AMRAP studies are conducted at four progressively more detailed levels to produce comprehensive assessments of the mineral and energy resources of Alaska. Level I studies are statewide in scope, and published maps are gen- erally at a scale of $1: 2,500,000$. No level I studies are being pursued at this time.

Level II studies address large parts of the State, and resultant maps are generally published at a scale of 1:1,000,000. Level II studies continue on the geology and mineral resource potential of the Alaska Peninsula and the eastern Alaska Range.

Level III studies consist of multidisciplinary evaluations involving team studies of selected 1:250,000-scale quadrangles; these continue to be the primary focus of AMRAP. Geologic, geochemical, and geophysical data are gathered to produce an inventory of areas defined to have mineral resource potential. Although numerous projects were either recessed or scaled down due to lack of funding, level III studies are in progress in 26 quadrangles. Field research is complete, and reports are in preparation, for the Baird Mountains, Bendeleben, Bethel, Chandler Lake, Iditarod, Killik River, Livengood, Mount Katmai, Naknek, Port Moller, Simeonof Islands, Solomon, and Stepovak Bay quadrangles. Fieldwork continues in the Atlin, Juneau, Lime Hills, Seldovia, and Taku River quadrangles. Pre-assessments have been completed for the Bethel, Lime Hills, Seldovia, Sitka, Sleetmute, and Table Mountain quadrangles. Level III AMRAP projects publish an assessment of the mineral resources of the quadrangle examined. To date, resource assessments have been published for 25 quadrangles (fig. 17). AMRAP-sponsored publications now number approximately 570 documents.

Level IV studies consist of detailed mapping (scale $1: 63,360$ or larger) of mining districts, specific mineral deposits, and related research. Current level IV activities include studies of the gold vein deposits in the Unga Island/ Apollo mine area on the Alaska Peninsula, geochemical studies of massive sulfide deposits in mafic volcanic rocks from the Chugach and Prince William terranes, and metamorphic and structural studies of the Brooks Range and central Alaska. Locations of level IV studies are shown in figure 18, and project titles are listed in table 8.

Some of the reports published in 1989 as a result of AMRAP and related USGS programs include mineral resource assessment of the Healy quadrangle (Cox and others, 1989), interpretation of reconnaissance geochemistry of the Healy quadrangle (King and others, $1989 \mathrm{a}$; Light and others, 1989), mineral resource assessment of the Petersburg quadrangle and parts of the Port Alexander, Sitka, and Sumdum quadrangles, southeastern Alaska (Brew and others, 1989), geochemical data for stream-sediment and pan-concentrate samples for the Solomon and Bendeleben quadrangles (King and others, 1989b; King and others, 1989c; Smith and others, 1989), and mineral and energy resource assessment of the Ugashik, Bristol Bay, and western Karluk quadrangles, Alaska Peninsula (Church and others, 1989b). These papers are listed in appendix 1, USGS section.

The fifth annual McKelvey Forum, entitled "Research on Energy Resources-1989," was held January 24- 


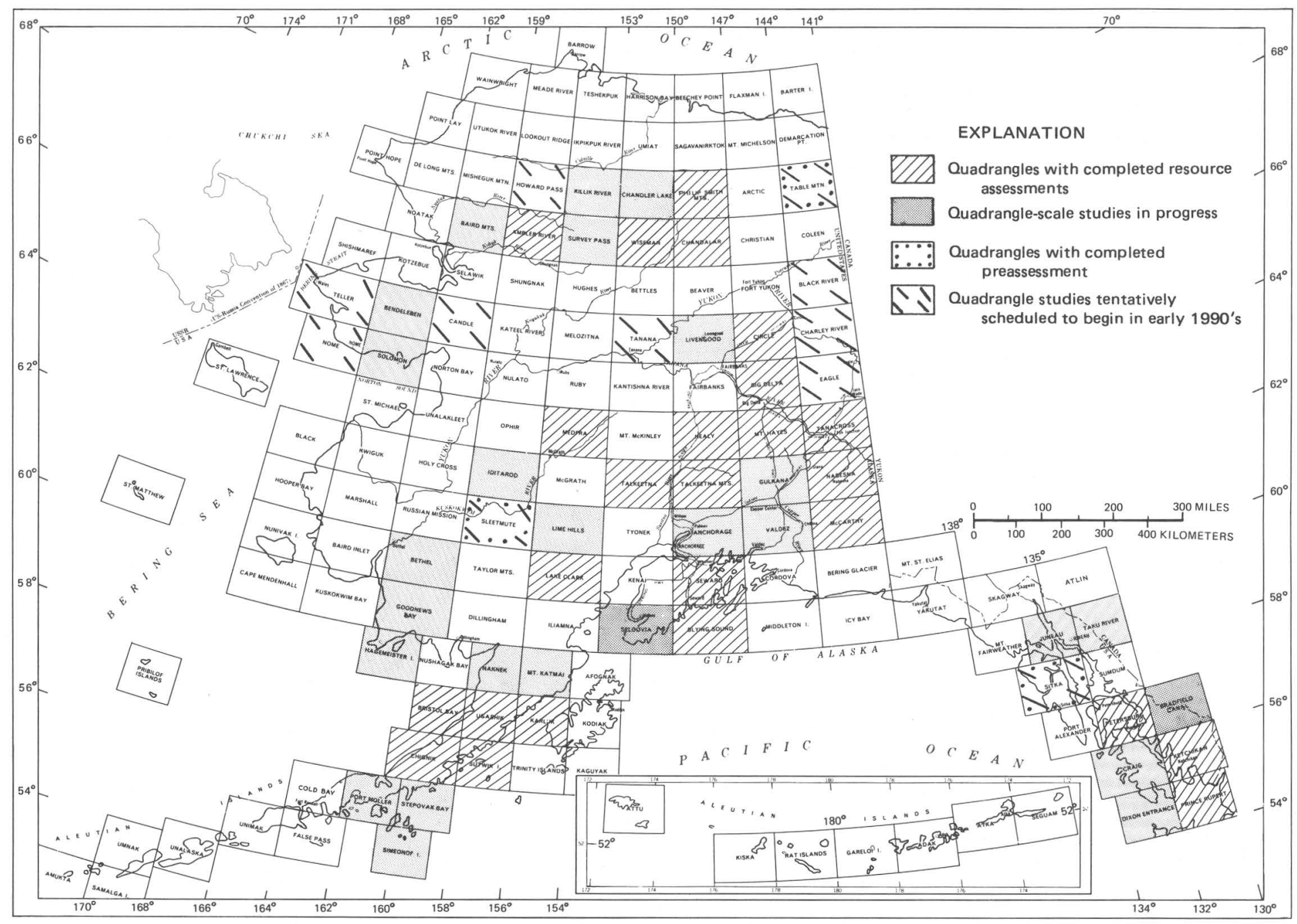

Figure 17. Status of USGS level III AMRAP quadrangle studies as of January 1990. 1:250,000-scale quadrangles are outlined and labeled. 


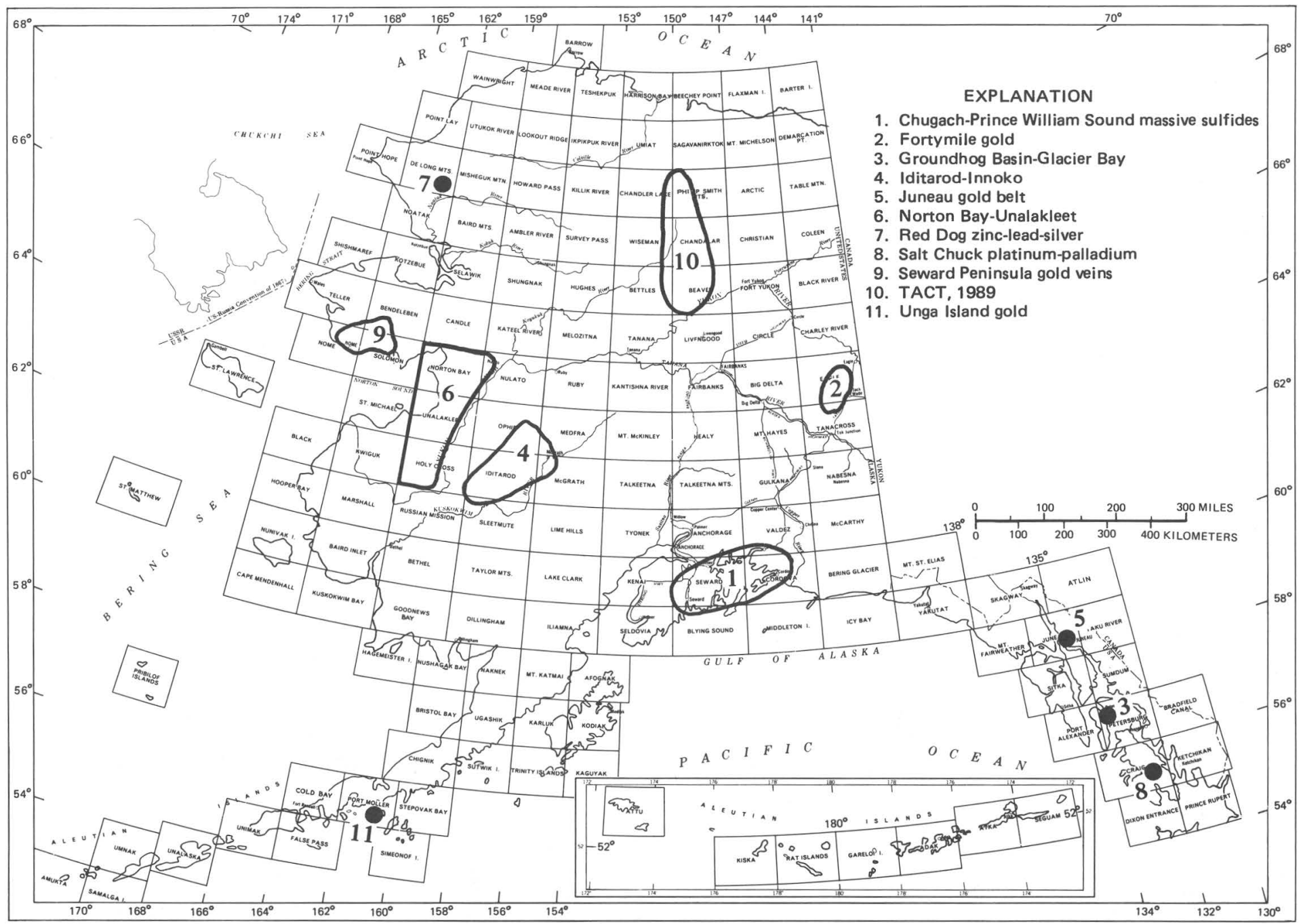

Figure 18. Locations of USCS level IV AMRAP metallic-mineral studies in 1989. 1:250,000-scale quadrangles are outlined and labeled. 
Table 8. Level IV studies of the USGS Alaska Mineral Resource Assessment Program and related studies active in 1989

[Project chiefs are listed in parentheses. Projects marked by an asterisk are of statewide scope]

\section{Areal mineral-resource assessments}

*Tin commodity studies (B.L. Reed)

*Placer gold deposit studies (W.E. Yeend)

*Subjective probability estimations of Alaskan mineral resources (W.D. Menzie)

Mineral deposits, westem Brooks Range (J.M. Schmidt)

Metallogenesis, eastern Alaska Range (W.J. Nokleberg)

Geology and mineral resources, Norton Bay-Unalakleet area (W.W. Patton, Jr.)

Tin and tungsten deposits, Circle district (B.L. Reed and W.D. Menzie)

Geology and mineral resources of the Alaska Peninsula (F.H. Wilson)

Areal energy-resource assessments

Petroleum potential of the Yukon-Kandik basin (H.E. Cook)

Geologic framework and petroleum potential of the Nenana basin (R.G. Stanley)

Coal studies in the Nenana basin (C. Wahrhaftig)

Genesis of trace elements of the Nenana basin coal fields (G.D. Stricker)

Coal resources of northern Alaska (G.D. Stricker)

Exploration geophysical studies

Geophysics of the Yukon-Koyukuk basin and its borderlands (J.W. Cady)

Mining geophysics of central Alaska (D.L. Campbell)

Biostratigraphic studies

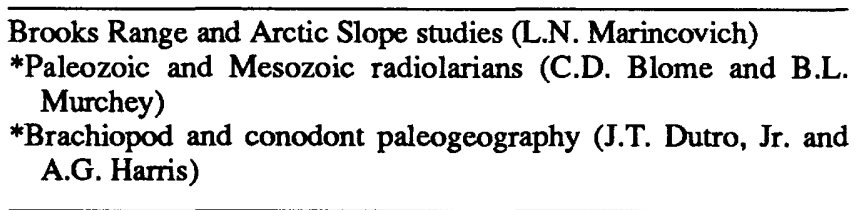

Framework or process studies

\footnotetext{
Yukon-Koyukuk crustal transect study (W.W. Patton, Jr.)

Structural analysis of interior metamorphic terranes (J.H. Dover)

Mafic and ultramafic rocks of Alaska (R.A. Loney)

Upper Mesozoic stratigraphy of the Alaska Peninsula (R.L. Detterman)

*Paleomagnetism of accreted terranes (C.S. Gromme)

*Metamorphic-facies map of Alaska (C. Dusel-Bacon)

Northwestern Alaska crustal study (A.B. Till)

Central Alaska metamorphic studies (J.H. Dover)

Gold mineralization of the Apollo and Shumagin Mines (W.H. White)

Radiometric ages and chemistry of the shallow Tertiary igneous rocks of the Mt. Katmai quadrangle (J.R. Riehle and M.A. Lanphere)

Origin of the Groundhog Basin-Glacier Basin silver-tin-lead-zinc deposits (R.J. Newberry and D.A. Brew)
}

Table 8. Level IV studies of the USGS Alaska Mineral Resource Assessment Program and related studies active in 1989-Continued

Exploration geochemical studies

Alaska placer gold deposits (J.B. Cathrall)

Southern Alaska lode gold deposits (R.J. Goldfarb)

Exploration geochemistry of epithermal $\mathrm{Hg}-\mathrm{Sb}$ deposits, southwestern Alaska (J.E. Gray)

Geochemistry of Brooks Range massive sulfides (K.D. Kelley)

Isotopic and radiometric studies

*K-Ar studies and radiometric age file (N. Shew)

*Lead and oxygen isotope studies (S.E. Church)

*Uranium-lead and rubidium-strontium isotope studies (J.N. Aleinikoff)

26,1989 , in Reno, Nevada. This forum was established to improve communication between the USGS and the earth science community. This year's forum included several oral and poster presentations on the results of research related to mineral resources in Alaska; abstracts are published in USGS Circular 1035 (Schindler, 1989).

Numerous short papers on the geology and mineral resources of Alaska will be published in USGS Bulletin 1946, "Geologic studies in Alaska by the U.S. Geological Survey, 1989" (Dover and Galloway, 1990).

Precious Metals

USGS geologists are involved in several studies of precious-metal occurrences in Alaska. Present research (fig. 18 , table 8) concentrates on gold-quartz veins north of Nome, lode-gold mineralization of the Apollo and Shumagin mines on the Alaska Peninsula, lode-gold deposits in southern Alaska, metallogenesis in the eastern Alaska Range, mining geophysics of central Alaska, and the geology of placergold deposits (fig. 19). Many level III AMRAP studies also involve some aspect of precious-metal deposits. Reports published in 1989 include fluid-inclusion geochemistry of gold-bearing quartz veins of the Juneau Gold Belt, southeastern Alaska (Goldfarb and others, 1989a), geochemistry of placer gold in the Koyukuk-Chandalar region (Mosier and others, 1989), epigenetic hydrothermal origin of the Groundhog Basin-Glacier Basin silver-tin-lead-zinc deposits, southeastern Alaska (Newberry and Brew, 1989), and multiple sources of gold in the Juneau gold belt (Newberry and others, 1989). These reports are listed in appendix 1, USGS section.

Strategic and Critical Minerals

USGS geologists are involved in several studies of strategic and critical metal occurrences in Alaska. Current 
research (fig. 18, table 8) includes studies of mafic and ultramafic rocks with associated deposits of platinum-group elements, chrome, nickel, and cobalt; tin commodity studies; and tin-tungsten deposits in the Circle district, eastcentral Alaska.

\section{Other Metals}

Studies of other metals and related geologic studies (fig. 18, table 8) are continuing on a northwestern Alaska crustal study, geology and mineral resources of the Norton Bay area, geophysics of the Yukon-Koyukuk basin and the Yukon-Koyukuk geologic transect, mining geophysics of central Alaska, metamorphic terranes in interior Alaska, stratigraphy of the Alaska Peninsula, compilation of mineral resource data for the Tongass National Forest in southeastern Alaska, and metamorphic facies maps of Alaska.

\section{Cooperative Programs with the USSR Academy of Sciences}

In 1987, joint studies were proposed during a visit of the Chief Geologist and Chief of the Branch of Alaskan Geology to the Soviet Far East Branch of the USSR Academy of Sciences. In 1988, as an outgrowth of these discussions, two study proposals were exchanged during a visit of five USGS geologists to the meeting of the Pacific Science Association in Blagoveshchensk in the USSR Far East. Both proposals involve reciprocal scientific visits of geologic

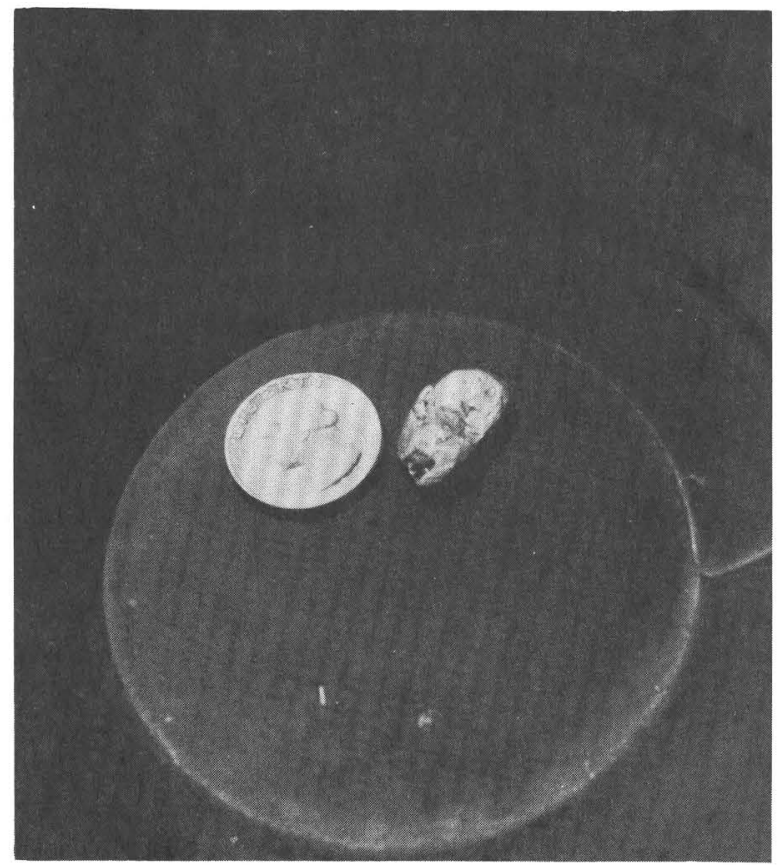

Figure 19. Placer gold nugget from interior Alaska, site of precious metals studies by USGS. Photograph by E. Bailey. teams for working conferences and field trips; goals are the publication of geologic maps, mineral resource maps, and interpretive scientific articles. Both projects officially began in 1989.

The first proposal involves a comparative study of the metallogenesis of lode mineral deposits in the USSR Far East and Alaska. This investigation will refine the trends of bedrock geology and lode mineral deposits across the outer continental shelf of western Alaska into the relatively unknown areas of the USSR Far East. In 1989, a team of USGS geologists visited the USSR Far East for 5 weeks; they toured offices and laboratories in Magadan, Khobarovsk, and Vladivostok, and visited field sites of significant geologic interest at Kolyma, the Koryak Mountains, and Primorye. Investigations included mines and deposits of quartz-vein gold, epithermal tin, tin granites, zoned mafic-ultramafic plutons with platinum-group metals (PGM), copper-lead-zinc-silver skarns, and boron skarns. In the summer of 1990, the USGS will host geologists from the USSR in Alaska.

The second proposal encompasses a joint study of the distribution and origin of ophiolites and associated rocks in Alaska and the USSR Far East. Ophiolites are generally interpreted as remnants of oceanic crust thrust onto continental margin areas, and are often the host rocks for PGM's, chromium, nickel, and cobalt lode deposits. Four Soviet geologists came to Alaska in July 1989 and toured ophiolites in Resurrection Bay, the Chugach Range, the YukonKoyukuk area, and the southern Brooks Range near Coldfoot. An exchange team of USGS geologists will visit the Soviet Far East in 1990.

Memoranda of understanding were signed between the USGS and the USSR Ministry of Geology, and between the U.S. National Science Foundation and the USSR Academy of Sciences. Topics being considered for mutual research efforts include comparative studies of respective mineral deposits, studies of the results of deep crustal drilling in the USSR, and comparison of resource-assessment techniques for oil and gas as well as for minerals (Hern and Sher, 1989).

\section{Trans-Alaska Crustal Transect Program}

Now in its sixth year, the Trans-Alaska Crustal Transect (TACT) program is a major multidisciplinary investigation designed to study the geology, tectonics, and deep crustal structure of Alaska along a corridor parallel to the Trans-Alaska Pipeline. Major results of the 1989 TACT program were (1) extension of 1:63,360-scale geologic mapping and specialized geologic studies on the southern flank of the Brooks Range, (2) analysis and synthesis of seismic-refraction and seismic-reflection data for the southern part of the transect, (3) completion of magnetotelluric surveys across central and northern Alaska and analysis of data for southern Alaska, and (4) presenta- 
tions and publications on the geology, tectonics, and geophysics of the study area.

\section{U.S. Bureau of Mines}

The USBM's AFOC is responsible for conducting four programs under the USBM's Directorate of Information and Analysis and for coordinating work with other USBM field and research centers throughout the United States. The USBM's Research Directorate is responsible for several ongoing projects in Alaska, through both the Mineral Institute program and the nine USBM research centers.

Minerals Availability Program

A USBM study to examine the impact of environmental constraints on lode and placer mining in Alaska was completed in 1989; publication is pending. The report examines the effect of regulations on the mining industry and the impact of water treatment options on placer mine feasibility.

In support of the USFS's revision of the Tongass Land Management Plan, the USBM performed an economic analysis of 171 known mineral deposits in and around the Tongass National Forest. Of the 171 deposits evaluated, 38 deposits had positive pre-tax net present values at zeropercent discounted-cash-flow rate of return. The analysis was designed for use in the Forest Planning (FORPLAN) and Interactive Policy Analysis Simulation System (IPASS) models developed by the USFS. The USBM's analysis was used by the USFS in conjunction with other resource information to simulate the economic consequences of alternative forest resources management policies.

Statistics on the use or proposed use and disposal of cyanide compounds by the Alaska mining industry were collected and forwarded to the USBM Western Field Operation Center in Spokane, Washington. The data will be included in a report, "Solution control strategies at domestic heap-leach operations," a survey of all such cyanide usage in the U.S. mining industry; the report is scheduled for release in 1990. Data on heap-leaching and its applicability to Alaska were published in "Arctic Research" by Herzog (1989). In that article, Herzog indicated that heap-leaching in Alaska is feasible, but problems would include cold weather freezing of the leach solutions, high development costs, and frost heaving. In addition, Alaska environmental regulations require operators to double-line their heaps, monitor ground water, then cap, seal, and monitor the heap for 5 years after the operation ends. The USBM Reno Research Center is working on technologies that might allow leaching in cold climates to be more economically feasible.

The Minerals Industry Location System (MILS) data base continued to receive widespread use by both the government and industry. In 1989, 38 reports and 27 maps were prepared in response to requests from the Bureau, other Federal and State agencies, and the public.
Policy Analysis

Two published reports summarized the availability of Alaska land for mineral exploration (Bottge, 1989a, 1989b). These reports culminated the USBM's program to inventory land-use constraints for locatable minerals in Alaska. A parallel report that describes various management policies toward leasing the rights to energy minerals is awaiting publication. Land status was updated for $\mathbf{4 8}$ quadrangles in southeast and central Alaska, and GIS was used to digitize this information for future use.

A prototype computerized data base of the Alaska State Kardex system was finalized and distributed to the Alaska Division of Mining and USBM offices in Alaska. The 2,378 Kardex numbers contain information on 79,066 individual claims $(45,185$ State and 33,881 Federal), crossreferenced by claim name, owner, Kardex number, serial number (Alaska Division of Lands and BLM), and location; the information is current through the end of 1988.

Two articles published by the USBM explored mineral policy in Alaska. The first, entitled "Mineral future of Alaska" (Hoekzema, 1989a), discussed Alaska's mining history and mineral potential, current constraints upon its mineral development, and suggested means to encourage development of its mineral industry. The second, entitled "Alaska's National Petroleum Reserve: Explore it before locking the door" (Hoekzema, 1989b), summarized what is known about mineral resources in NPRA and argued that additional mineral resource information should be obtained in order to make wise land-use and mineral policy decisions.

\section{State Mineral Activities}

The State Mineral Officer wrote the annual preliminary "Mineral industry survey of Alaska in 1989," summarizing significant nonfuel mineral activity. "The mineral industry of Alaska in 1988," detailing major nonfuel mineral exploration, development, production, and legislative action in the preceding year, became the Alaska chapter in the annual Minerals Yearbook, volume 2, published by the USBM. Legislative and executive actions of interest to the mineral industry were monitored and reported monthly. News items were prepared for the weekly "Mineral Alerts" and the bimonthly survey "Minerals and Materials." Mineral briefing profiles were prepared for DOI and USBM officials as required. Mineral news of interest to the USBM and its commodity specialists were forwarded weekly.

Minerals information and analysis are provided through a series of scheduled and unscheduled publications and reports and through other responses to inquiries from State and Federal agencies, industry, and the public. A priority activity is identifying and evaluating issues, problems, and trends to provide the USBM additional opportunities for constructive action in the minerals field. 
Table 9. Areas of U.S. Bureau of Mines activity in mining districts and at strategic and critical mineral localities in 1989

The USBM conducted mineral land assessment activities during 1989 in the Juneau, Ketchikan, and Valdez Creek mining districts (fig. 20, table 9).

Southeastern Alaska.-In 1989, the USBM completed the compilation of results from its 4-year study of the Juneau mining district. The final three-volume report will be published during 1990 . Volume 1 will be an executive summary; volume 2 will be a detailed description of mines, prospects, and mineral occurrences; and volume 3 will cover the industrial minerals in the district. A report describing the lode mineral deposits of the Porcupine mining subdistrict in the Juneau area was published (U.S. Bureau of Mines, 1989), and USBM work in the Juneau mining district was presented in a paper at the Alaska Miners Association regional meeting in April (Baggs, 1989).

In the fall of 1989 , the USBM started a study of the Ketchikan mining district. Fieldwork for this study will be at the same level of effort as for the Juneau mining district study and is scheduled to begin in the summer of 1990. Activities during 1989 consisted of literature searches, coordination with private groups and other agencies, and planning for the 1990 field season.

Data on mineral development potential in the Tongass National Forest were compiled for the USFS. Areas of high mineral-development potential have been integrated into the Forest Service's GIS, so that minerals may be readily compared to other commodities and land uses. The USBM also conducted mining and minerals orientation courses for USFS personnel.

Valdez Creek.-The USBM's work in the Valdez Creek mining district is part of a 4-year project begun in 1987. The study will identify the type, amount, and distribution of mineral deposits, evaluate probable reserves using computerized statistical analysis, examine ore beneficiation technologies, finalize economic feasibility studies, and address economic and legislative effects on mineral development. The program is a cooperative effort involving the USBM and ADGGS.

In 1988, reconnaissance sampling in the district resulted in the identification of four previously unreported gold placer occurrences, five placer occurrences with detectable levels of platinum and palladium, five new goldsilver lode occurrences, two lode occurrences with elevated quantities of chromium, cobalt, nickel, palladium, and platinum, and one lode occurrence with elevated quantities of copper, molybdenum, and zinc (Balen, 1989). Fieldwork in 1989 concentrated on additional reconnaissance sampling, an examination of the industrial minerals, and detailed examination of the mineralized areas identified in 1988. Results of the 1989 work will be published in 1990.

In 1988, the USBM also discovered a new goldsilver occurrence in the western part of the district, 10 miles west-northwest of Honolulu Creek on the Parks Highway.
[Locations shown on figure 20. REE, rare-earth elements; PGM, platinum-group metals

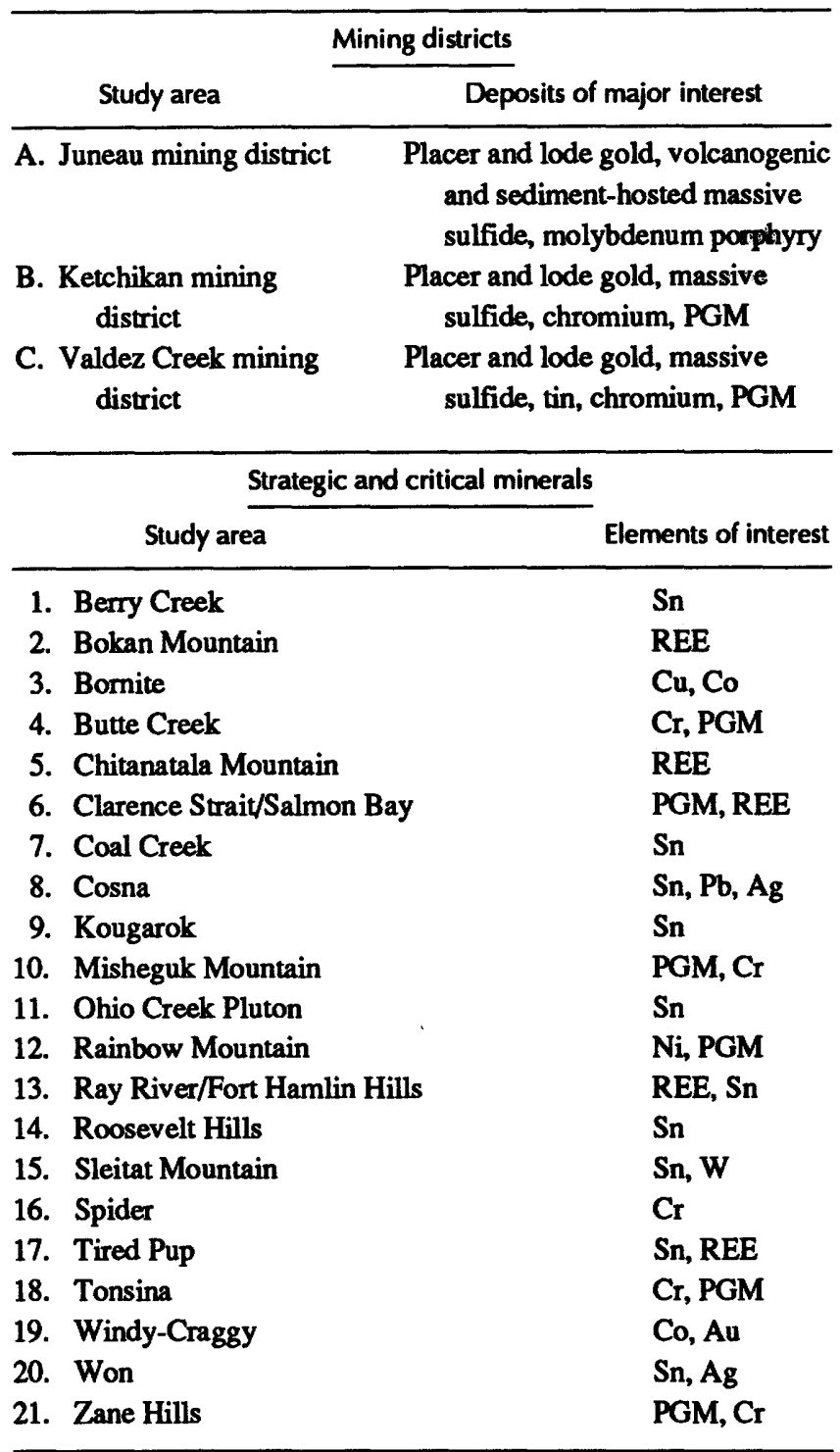

Mineralization consists of a zone 100 to 150 feet wide with sulfide-bearing quartz veinlets containing arsenopyrite, chalcopyrite, and pyrrhotite. Samples contained up to 0.88 $\mathrm{oz} / \mathrm{t}$ gold, $4.2 \mathrm{oz} / \mathrm{t}$ silver, and more than 1 percent each lead, zinc, and antimony. This information, released in early 1989 , led to the staking of the occurrence by Edwin Grover.

ADGGS has been mapping the geology of seven quadrangles in the central part of the Valdez Creek mining district at a 1:63,360 scale. ADGGS also conducted geochemical sampling around a lode gold deposit in Valdez Creek and mapped the glacial geology of a portion of the district (Reger and Bundtzen, 1990; Smith and others, 1989; Wiltse and Reger, 1989; Wiltse and others, 1989). These four papers are listed in appendix 1, ADGGS section. 


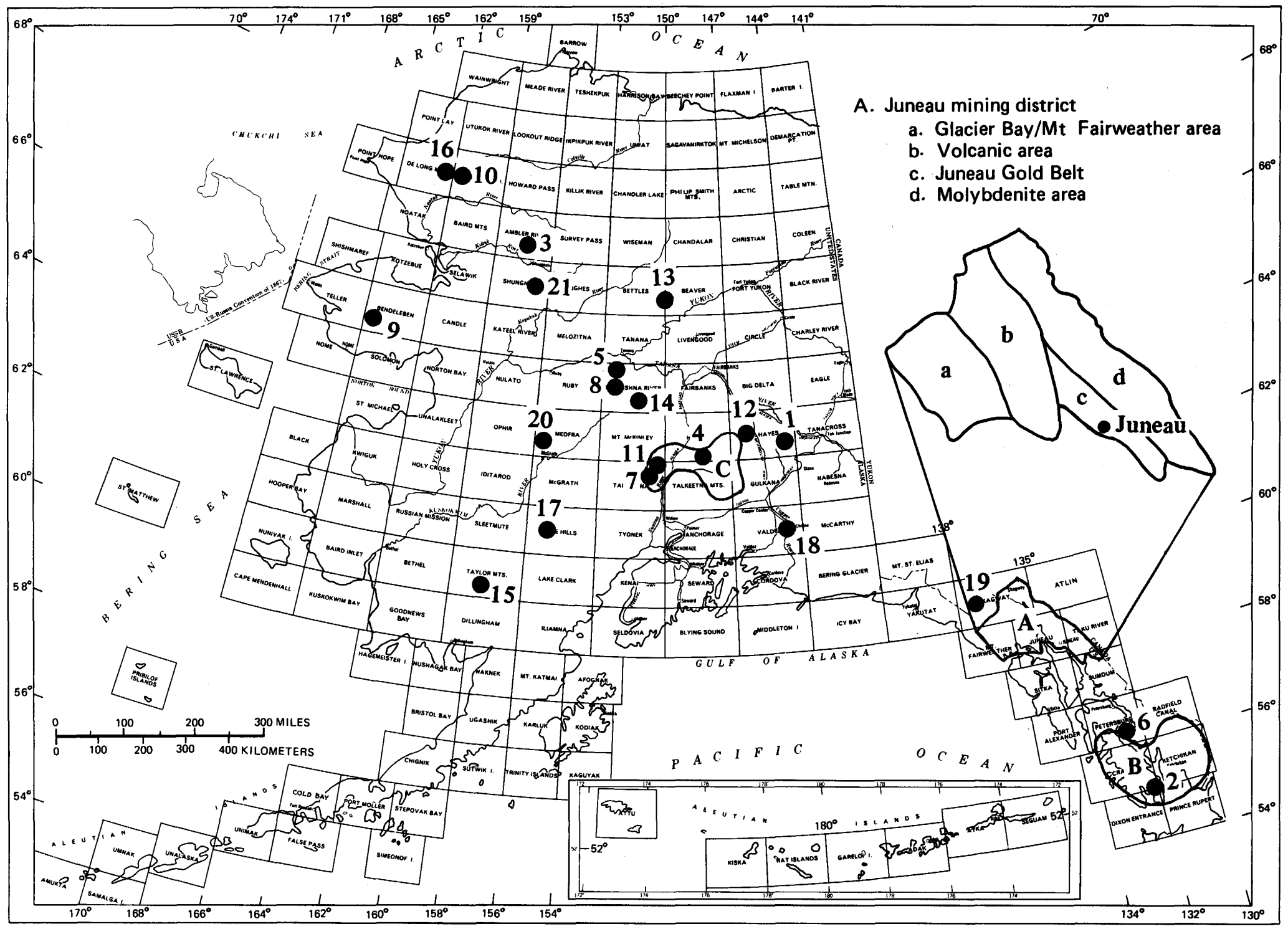

Figure 20. Locations of 1989 USBM mining district studies $(A, B, C)$ and studies of strategic and critical minerals (1-21) listed in table 9. 1:250,000-scale quadrangles are outlined and labeled. 
Strategic and Critical Minerals

As part of the studies mandated by ANILCA, the USBM is evaluating occurrences of strategic and critical minerals throughout Alaska (table 9). Project work in 1989 evaluated deposits that contain tin, rare-earth elements (REE), niobium, chromium, and PGM's. Mineral samples previously collected and analyzed by USBM personnel were analyzed anew for bismuth, gallium, germanium, hafnium, PGM's, REE's, tellurium, and zirconium. A data base containing the results of these new analyses has been started. Literature searches of sedimentary manganese and vanadium occurrences were also started. Locations of the following study areas are shown on figure 20.

Interest in the REE-yttrium deposits on southern Prince of Wales Island prompted an early release of the Bureau's final report on the Bokan Mountain area (Warner and Barker, 1989). Deposits at Bokan Mountain are estimated to contain 40 million tons grading 0.5 percent REE's, with minor amounts of niobium, zirconium, hafnium, beryllium, tantalum, and uranium. Half of the REE's occur as the heavy yttrium subgroup. The Bokan Mountain deposits represent the largest U.S. source of yttrium yet reported.

The USBM conducted a reconnaissance evaluation and bulk sampling of the Sleitat tin deposit in southwestern Alaska. The Sleitat deposit is the largest tin deposit in the United States. The USBM's Salt Lake City Research Center (SLRC) has begun metallurgical and beneficiation studies of the Sleitat bulk samples. SLRC also completed a report describing successful recovery techniques for the metals in the Kougarok tin-niobium-tantalum deposit on the Seward Peninsula. Using a bulk sample from a large low-grade nickel-PGM deposit near Rainbow Mountain in the Alaska Range, SLRC is beginning studies to determine a technology for the economic extraction of platinum-group elements from low-grade PGM-bearing materials. In addition, SLRC is trying to determine a technologically feasible method to recover cobalt from the Windy Craggy copper-gold-cobaltmassive sulfide deposit in Canada near the Alaskan border and the Bomite copper deposit in northwest Alaska.

Work continued to characterize the mineralogy of the ore zones and alteration haloes at the Coal Creek tin deposit in the Alaska Range. The project is being conducted in cooperation with the University of Alaska-Fairbanks and ADGGS.

Other projects, begun in previous years, were completed in 1989. Open-file reports were published on the tinlead-silver mineralization in the Cosna area (Burleigh, 1989), on REE-bearing carbonate veins at Salmon Bay (Warner, 1989), and on tin associated with the Ohio Creek pluton (Warner and Dahlin, 1989). A review of coastal and continental shelf mineral occurrences was presented at a technical conference in Houston (Barker and others, 1989). These reports are listed in appendix 1, USBM section.

Alaskan-type ultramafic complexes were investigated at Blashke Islands, Duke Island, Mount Bumett-Union Bay, and Salt Chuck, all located in Clarence Strait, southeastern Alaska. Anomalous concentrations of PGM's, with traces of gold, were found at all the sites visited during the 1989 reconnaissance investigations.

In conjunction with the Valdez Creek mining district study, PGM investigations were conducted at three sites in the central Alaska Range. Two of these sites proved to be along the southwestern continuation of a 120-milelong belt of intrusive mafic and ultramafic igneous rocks in the eastern and central Alaska Range. PGM's occur in a variety of geologic and mineralogic settings in this belt (Foley and others, 1989). During the 1989 investigations, PGM's associated with copper, nickel, and gold were detected in intrusive igneous rocks at Butte Creek and Eureka Glacier. Similar mineralization was also found in the ultramafic rocks of an unrelated alkaline gabbro complex on Eldorado Creek, a tributary to Valdez Creek.

An orientation survey in the vicinity of chromiumand PGM-bearing rocks in the Chugach Mountains near Tonsina was conducted cooperatively by the USBM, USGS, and ADGGS. Its aim was to determine if PGM's are concentrated in alluvial placer deposits downstream from known lode deposits. The study was also designed to determine analytical and sampling variance. Analytical data will be available in 1990.

A cooperative project by the USBM, USGS, ADGGS, and a faculty member of West Virginia University was conducted in the western Brooks Range ophiolite complex in the Noatak National Preserve in northwestern Alaska. Field studies included an orientation survey similar to that in the Chugach Mountains and follow-up work on previously discovered chromium and PGM occurrences. A large podiform chromite occurrence and several smaller ones were discovered (fig. 21). These are estimated to contain between 223,000 and 1.6 million short tons of chromic oxide $\left(\mathrm{Cr}_{2} \mathrm{O}_{3}\right)$. The largest of these, the Spider chromite deposit, may contain over 1 million short tons of $\mathrm{Cr}_{2} \mathrm{O}_{3}$, making it as large as the largest known chromite deposit in the State, the Turner Stringer Zone chromite deposit at Red Mountain on the Kenai Peninsula.

A PGM-bearing chromium occurrence at Misheguk Mountain was also investigated in 1989. Samples from this occurrence contain up to $0.27 \mathrm{oz} / \mathrm{t}$ PGM's and are chemically, mineralogically, and petrologically similar to the highgrade PGM-chromium occurrences near Tonsina. Beneficiation studies by the USBM Albany Research Center have been performed on chromite samples from both the Chugach Mountains and the Brooks Range localities.

\section{Research Activities}

Bulk samples of strategic and critical ores from various parts of Alaska have been sent to USBM research centers in Albany, Oregon, and Salt Lake City, Utah, in order to characterize their mineralization and to determine 
the best beneficiation techniques for minerals recovery. Materials from the Sithylemenkat and Coal Creek tin deposits, Misheguk Mountain chromite-PGM deposits, Stone Rock Bay, Dora Bay, and Bokan Mountain REE deposits, and the Red Mountain chromite deposit are now being evaluated. Manuscripts documenting work on the Big Hurrah tungsten, Goodnews Bay PGM's, Sheep Creek tin-leadzinc, and Kougarok tantalum-niobium deposits are in final editorial stages.

Researchers from the Spokane Research Center continued investigations under a program to develop technology for underground mining of deep placers. Work included additional physical property tests such as permeability and shear strength on samples from the Valdez Creek placer mine, numeric modeling of alternative mining methods, and initial tests of soil samples from the Goodnews Bay placer deposit. A new project at the Spokane Research Center will examine aspects of mine closure in arctic and subarctic environments. Reclamation, revegetation, slope stability, groundwater quality, long-term monitoring of mine sites, bonding, and environmental liability are some of the issues being examined. Researchers are contacting all land-management agencies to discuss and evaluate current practices.
Under the USBM Mineral Institute program, researchers at the University of Mississippi's Marine Minerals Technology Center continued to test a new remote-controlled underwater sampling device offshore near Nome. Work was done in cooperation with WestGold, which provided the vessels for offshore testing. If further work is successful, this tool could replace the cumbersome placersampling drill of present usage, significantly reducing the cost of offshore resource assessment work.

Also under the Mineral Institute program are several projects at the School of Mineral Engineering, University of Alaska-Fairbanks. This program receives 2:1 matching funds from the State of Alaska, which, combined with USBM funds, are used for various faculty and graduate student mini-projects, scholarships, and other appropriate mineral industry activities.

The USBM continues to support the operation of the Army Corps of Engineers CRREL permafrost tunnel near Fox. Support funds routine maintenance of the facility and is shared equally with the Corps of Engineers and University of Alaska-Fairbanks.

Finally, the USBM Research Directorate maintains the ATTO in Anchorage. Professionals with backgrounds

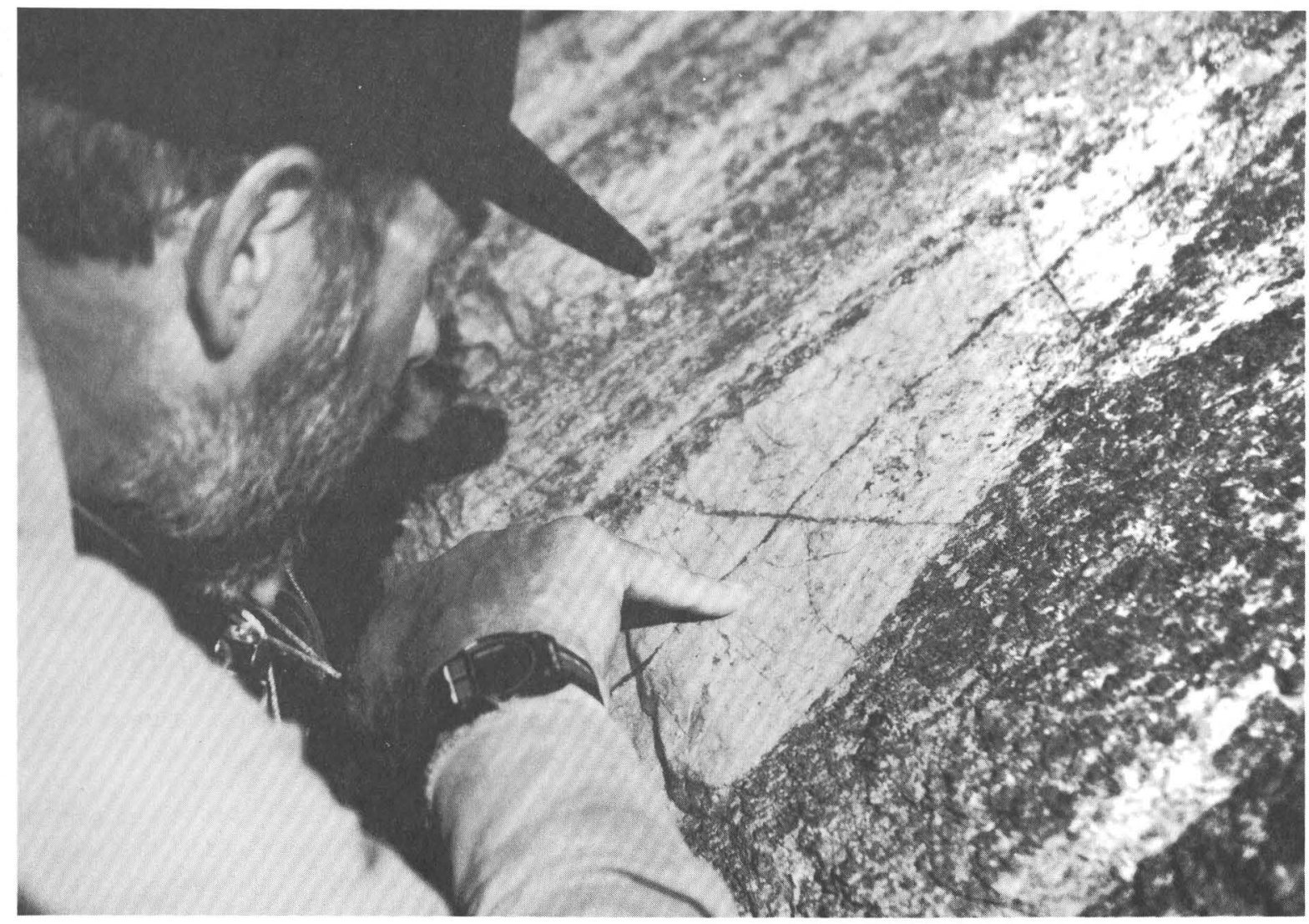

Figure 21. ADGGS geologist examines outcrop of chromite deposit in Avan Hills, western Brooks Range, northwestern Alaska. Photograph by J. Foley. 
in mining engineering and metallurgy staff this office; their goals are to (1) work with various government agencies, the State, universities, and industry on technology issues and needs, (2) conduct technology transfer briefings and attend various meetings, (3) identify needs that can be met at existing USBM facilities, and (4) seek opportunities where ongoing USBM research can be field tested in Alaska.

\section{Bureau of Land Management}

During 1989, BLM completed its studies of the cumulative and synergistic impacts of placer mining on four watersheds, and on subsistence uses and resources in those watersheds, in interior Alaska. The final EIS's and corresponding Records of Decision for the four studies were submitted to the court on February 10, 1989 (Beaver Creek), April 21, 1989 (Birch Creek), April 27, 1989 (Fortymile River), and May 18, 1989 (Minto Flats); all were accepted without challenge. By June 8, 1989, all four injunctions issued in the 1988 Sierra Club $v$ Penfold litigation were dissolved.

In 1989, there were filings/recordings of a total of 27,621 Federal mining claims in Alaska. The total number of active mining operations on BLM-administered lands was 157 Notices (5 acres or less total surface disturbance) and 88 Plans of Operations (greater than 5 acres of total surface disturbance). One mineral patent for four gold claims conveying 79,985 acres into private ownership was issued by BLM during fiscal year 1989. Additionally, a decision denying patent of 153 mining claims was issued for lack of diligence and sufficient title evidence on the part of the applicant.

Work continued on an automated minerals database for BLM lands containing BLM-generated mineral potential information, minerals data (well, seismic, etc.) and a minerals bibliography. Technical papers were presented at the 28th International Geological Congress in Washington DC in July 1989 on platinum-palladium mineralization in mafic and ultramafic rocks in northwest Alaska and on the Red Dog mineral deposit (Mowatt, 1989a,b).

\section{Fish and Wildlife Service}

In keeping with its primary mission, efforts of the FWS relating to mineral activity emphasize fish, wildlife, and habitat protection. However, some mining claims had been located before the wildlife refuges were established. By the end of 1989, the number of active mining claims on refuge lands had been reduced to 123 claims on 8 of the 16 refuges. Most of the remaining placer mines are in the Togiak and Yukon Delta National Wildlife Refuges, and most of the lode mines are in the Alaska Peninsula National Wildlife Refuge (fig. 4).

Contaminant sampling was conducted at and downstream from mines: on Braided Creek in the Alaska Penin- sula National Wildlife Refuge; the Chatanika River, Goldstream Creek, Tolovana River, Tanana River, and Tatalina River running into Minto Flats; the Nabesna River, Chisana River, and Cheslina River in the Tetlin National Wildlife Refuge; the Tuluksak River, Columbia Creek, Canyon Creek, and Discovery Creek in the Yukon Delta National Wildlife Refuge; and within the 1002 area of the Arctic National Wildlife Refuge. In the 1002 area, streams, bay/lagoon, and terrestrial sites were sampled to establish baseline data in areas where potential oil and gas development could occur. The FWS also commented on EIS's for offshore gold dredging in Norton Sound in western Alaska, and on the A$\mathrm{J}$, Herbert Glacier, Kensington, and Quartz Hill mines in southeastern Alaska.

With respect to placer mining activities, the FWS reviewed and commented on 25 Section 404 permit applications for projects in the Fairbanks-Circle, Fortymile, Seward Peninsula, and southern Brooks Range areas. The FWS also reviewed and commented on three EIS's and three National Pollution Discharge Elimination System permits for placer mining proposals.

Minerals Management Service

OCS Mining Program, Norton Sound Lease Sale.The MMS has proposed a competitive OCS mineral lease sale in Norton Sound south and southeast of Nome on the Seward Peninsula (fig. 16). The sale focuses on gold-bearing placer deposits at or near the sea floor in Federal waters at depths ranging from 60 to 100 feet. The proposed sale includes an area of 147,050 acres that extends up to 10 miles seaward of the State of Alaska's 3-mile coastal limit. Preliminary studies indicate that the sale area could yield as much as $1,060,000 \mathrm{oz}$ gold, although expected production is estimated at $530,000 \mathrm{oz}$.

Industry responses to a Request for Comments and Nominations in March 1988 revealed that sufficient interest existed to justify proceeding with an offshore gold sale. Onshore mining of stream placers and beach placers near Nome has occurred intermittently since the first gold discoveries in 1899. Since that time, more than 6 million oz gold has been recovered from the Seward Peninsula, of which 4.5 million oz came from the Nome district alone. For the past four years, WestGold has used the floating dredge Bima to mine 21,750 acres of mineral leases in State of Alaska waters landward of the proposed sale area; approximately $104,200 \mathrm{oz}$ gold has been extracted during that time.

The Norton Sound OCS minerals lease sale is planned for February 1991. If the sale is held on schedule, detailed prospecting of the deposit could begin in the 1991 ice-free season. It is estimated that production could begin as early as the fourth year following the sale. A timetable for the lease sale includes the following key events: (1) Proposed Action and Alternatives Memorandum and Up- 
date Decision Memorandum circulated and implemented, (2) draft EIS published, June 1990, (3) proposed leasing notice published, June 15,1990 , (4) proposed leasing notice comment period closed, August 15, 1990, (5) final EIS published, December 1990, (6) final leasing notice published, January 1991, (7) lease sale, February 1991.

\section{National Park Service}

The NPS Alaska Regional Office, Minerals Management Division, is organized into two branches: Resource Assessment, and Mining and Minerals. Personnel from both branches review mining plans of operations and evaluate available natural, cultural, and physical engineering information on areas subject to mineral-related operations. They also conduct claim validity examinations and develop and implement long-term reclamation programs. In addition to the Regional Office, the Denali and Wrangell-St. Elias National Parks and Preserves have professional minerals-management staffs of environmental specialists and geologists or mining engineers who implement park-specific aspects of the minerals-management programs. Major accomplishments during 1989 are detailed below.

1. The NPS received five plans of operations for proposed mining activities in Kenai Fjords National Park, Bering Land Bridge National Preserve, and Wrangell-St. Elias National Park and Preserve. After processing and review, two plans were determined to be complete and received approval by the end of the calendar year.

2 . To clarify confusion on whether plans of operations were required for operations on patented claims that could be accessed without crossing National Park System lands, NPS regulations 36 CFR 9 Subpart A were modified (August 1988) to indicate that plans of operations are required on all patented and unpatented 1872 mining claims without regard to access.

3. Mineral examinations for claim validity determinations were made on 24 placer and 2 lode claims in two park units.

4. Field investigations were conducted for engineering and environmental analyses on proposed plans of operations and reclamation activities. Additionally, natural resource inventories and evaluations were performed on areas subject to mineral-related activity in two park units.

5. The Cultural Resource Division continued to evaluate all mineral-related activities under the mandates of the National Historic Preservation Act. Multidisciplinary cultural-resource field crews conducted intensive pedestrian surveys in six park units. A total of 1,200 acres was surveyed, and 36 cultural resource sites were documented. Site types ranged from 6,000-year-old prehistoric sites to large gold-rush mining camps.

6. The second phase of the Glen Creek Reclamation Project was accomplished along 2.3 miles of Glen Creek in Denali National Park and Preserve. The purpose of this project is to restore a more natural appearance to the drainage and to assist in the revegetation of the site. In 1988, mine tailings were recontoured, available topsoil was redistributed, and abandoned structures, equipment, and debris were removed from 27 acres of abandoned placer mining claims. Native plants from park sources were transplanted into the reclaimed areas in 1989. Experimental revegetation studies will be conducted on these areas, providing current data for use in mining and reclamation plan reviews.

7. The Alaska Region has instituted an Abandoned Mineral Lands (AML) program. The program's objectives are (1) to eliminate or mitigate health and safety hazards associated with abandoned mines and oil and gas sites, as well as their associated access routes, support sites, structures, and equipment, (2) to mitigate the degradation of natural and cultural resource values, and (3) to reduce the potential liability of the NPS for death, injury, or loss of property resulting from unsafe, abandoned mine sites. In 1989, work was primarily directed toward organization of the AML program. This included literature research and organization of existing inventories. The magnitude of this problem is much greater then originally anticipated. Thousands of records exist for both abandoned and current mining claims. Continued inventory and site inspection is planned for 1990. Reclamation of some sites may be initiated.

8. Photopaneling and surveying of 75 mining claims in four park units were completed.

9. Color infrared and black and white aerial photographs were taken of claim areas in Denali, Gates of the Arctic, and Wrangell-St. Elias National Parks and Preserves.

10. By adapting commercially available GIS computer software, NPS has developed three-dimensional models of the topography of the mining areas (including claims) within park units. This allows the automation of many sitespecific engineering analyses for mining plans of operation and reclamation proposals. Examples include the generation of cross sections, cross-sectional areas, volumes, profiles, areal analyses, stream and roadway gradients, and stream sinuosity, all in both tabular and graphic form. An additional benefit is the automation of all required technical output of the analysis, including graphs, charts, and accurate map production at any scale.

Other.-On May 9, 1985, the Northern Alaska Environmental Center, et al., sued DOI over noncompliance with NPS mining regulations in Alaska. An injunction was issued suspending approval of all existing mining operations in National Park System units in Alaska, and requiring EIS's for three of the parks. Interim court rulings and decisions are summarized in the "1989 Annual report on Alaska's mineral resources" (Schneider, 1989, p. 51-52). On March 3, 1988, the U.S. District Court for Alaska issued a Final Judgment and Stipulation which (1) restated the requirement to prepare environmental impact statements for Denali National Park and Preserve, Wrangell-St. Elias 
National Park and Preserve, and Yukon-Charley Rivers National Preserve, (2) enjoined the NPS from approving proposed plans of operation in the three parks until EIS's are completed, (3) voided mining permits and temporary approvals for plans of operation issued before July 24,1985 , (4) voided 36 CFR 9.10 (c) to the extent that it was contrary to existing law, (5) required that access to mining claims be permitted in accordances with 43 CFR 36 and by way of specific, stipulated routes, and (6) settled or dismissed the remaining issues in the case. For the other National Park System units in Alaska, mining plans could be submitted and approved by the NPS for operations if all regulatory requirements were met, including the completion of environmental assessments and a finding of no significant impact.

During 1989, NPS operations conformed to the conditions of this Final Judgment and Stipulation. Drafts of the Final Environmental Impact Statements (FEIS's) for the three park units were completed in December 1989, and the FEIS's were released to the public in May 1990. The preferred alternative identified in each of the three documents is the acquisition of all patented and valid unpatented mining claims in these units of the National Park System. Pending appropriation by Congress of monies for the proposed claim acquisitions, the NPS will continue to evaluate completed plans of operations, and approve those operations that are acceptable under the Mining in the Parks Act regulation standards of 36 CFR 9, Subpart A. Approval of the FEIS's by the U.S. District Court will lead to a lifting of the 1985 injunction against mining in these parks.

\section{U.S. Forest Service}

Greens Creek.-Greens Creek (fig. 16), one of the largest mining developments in southeastern Alaska, is in Admiralty Island National Monument, administered by the Tongass National Forest. Development and production is authorized by Section 503(f)(2)(A) of ANILCA. The USFS completed an EIS for the project in January 1983. Under the provisions of ANILCA Section 503(e)(1), USFS mineral examiners evaluated nine new mining claims, notifying the Greens Creek Mining Company in September 1988 that the claims were valid, thus increasing the viable ore reserves of the mine. The mine was aggressively developed, and production began in January 1989.

In August 1987, the Sealaska Corporation proposed to exchange mineral lands owned by the Native corporation in the Cube Cove area of Admiralty Island $\mathrm{Na}$ tional Monument for Federal mineral lands in the vicinity of the Greens Creek project. The USFS determined that the tracts to be exchanged were not of equal value and that the exchange proposal was not in the best public interest. Subsequently, an amendment was attached to Tongass timber reform legislation that, if passed, would authorize a variation of the proposed exchange.
Quartz Hill.-U.S. Borax and Chemical Corporation's Quartz Hill molybdenum deposit (fig. 16) is in Misty Fjords National Monument, on a 152,000-acre tract that is excluded from designation as wilderness. Section 503(f)(2)(A) of ANILCA provides for the evaluation and development of the deposit. The USFS was the lead agency for the mine development FEIS, which was released in October 1988. Two alternatives for marine tailings disposal were considered in the FEIS: disposal in the Boca de Quadra fjord, and disposal in the Wilson Arm/Smeaton Bay fjord. In his Record of Decision, the Regional Forester for the Alaska Region chose the Wilson Arm/Smeaton Bay fjord for the tailings disposal site, concluding that there was little difference between the two fjords in the environmental effects of tailings disposal. In Wilson Arm, however, the impact of mine development would be confined to a single drainage, greater community stability would ensue for Ketchikan and southeast Alaska, and mine shutdowns would be fewer and of shorter duration due to a reduction in mine operating costs. The EPA, a cooperator in the preparaton of the original Mine Development EIS, issued a draft discharge permit in November 1988.

The Sierra Club Legal Defense Fund (SCLDF), on behalf of several environmental and commercial fishing organizations, appealed the Regional Forester's decision in November 1988. They contended that, due to the environmental sensitivity of Misty Fjords National Monument, economics should not have been an element of the Regional Forester's decision. In January 1989, the Regional Forester reaffirmed his decision, noting that Congress specifically directed the USFS to consider the effect of mitigation on the economic viability of the project. However, in May 1990, the EPA reversed itself and announced plans to deny the disposal permit. Since many of the issues cited by the EPA as reasons for their reversal are similar to those at issue in the administrative appeal, the Alaska Regional Forester asked the EPA to suspend further action on their draft permits until the appeal has run its course. The Chief of the USFS should make a decision on the SCLDF's appeal by the end of 1990.

Other.-There is a considerable amount of exploration and development activity in the Juneau gold belt (fig. 16) of the Tongass National Forest. The Juneau Ranger District is in the process of preparing a mine development EIS for the Kensington lode-gold project.

Since the summer of 1984 , the USFS has been conducting mineral validity examinations on mining claims located in National Forest wilderness lands. These examinations are conducted for the purpose of establishing valid existing rights. If these rights are established, then the claimants can proceed with certain exploration and development activities. To date, five such examinations have been completed, four in the West ChichagofYakobi Wilderness and one in the Stikine-LeConte Wilderness. 
Work is continuing on the the revision of the Tongass Land Management Plan. Mineral resource data, including areas of mineral interest, claim staking and exploration activity, USGS publications, and field investigations, are being used to update the existing data base. This information will be used to determine areas of the Tongass where mineral exploration and development are most likely to occur and to assist in making the appropriate land allocation decisions and recommendations. A draft of the plan was scheduled for release in June 1990.

\section{Industrial Minerals}

The use of nonmetallic nonfuel resources decreased significantly in 1989 due to the lack of oil-and-gas infrastructure development on Alaska's North Slope and the continuing lull in urban-area construction projects (Bundtzen and others, 1990). Sand and gravel production fell 16 percent to 14.4 million short tons, and the production of building stone fell 19 percent to 2.9 million short tons (table 7).

Jade and soapstone production increased fourteenfold over 1987 levels (no values available for 1988). A total of 57 short tons was produced at a value of $\$ 1.1$ million (table 7 ).

The Chugach National Forest has received requests for exploration and testing of travertine resources on two mining claims near the lower Russian River. The travertine would be used as an agricultural soil conditioner (Alaska Journal of Commerce and Pacific Rim Reporter, December 26,1988 ).

Glacial ice derived from the spontaneous calving of tidewater glaciers in south-central Alaska is being collected for export to Japan by Wetco and by General Communications (Anchorage Times, October 21, 1989). The naturally blue-colored ice is used in exotic drinks and is a status symbol among Japanese citizens and corporations. The Alaska Department of Natural Resources reported several new applications for permits to collect glacial ice in Prince William Sound, in Kenai Fjords National Park, and in Icy Bay (Anchorage Daily News, December 11, 1989).

\section{Activity by Federal Agencies}

\section{U.S. Bureau of Mines}

The industrial minerals of the Valdez Creek mining district were evaluated in 1989; results will be published in 1990. Another report summarizing the industrial minerals of the Juneau mining district also will be published in 1990.

\section{Bureau of Land Management}

The disposal of salable mineral materials, namely sand and gravel, continued to be a minor activity for BLM in Alaska. In 1989, BLM made 10 mineral material sales; production from these actions totaled 8,220 cubic yards.

\section{Fish and Wildlife Service}

The FWS permitted several small sand and gravel operations on refuges and provided comments to the Corps of Engineers on approximately 26 applications for sand and gravel removal permits throughout the State.

\section{U.S. Forest Service}

Annually, the USFS permits the removal of many thousands of tons of sand, gravel, and stone. Nearly 2.8 million tons of this material, in the form of quarried stone, is used for the construction of timber sale roads. Lesser amfounts are used by State and local governments for the construction and maintenance of breakwaters, airports, and roads.

\section{REFERENCES CITED}

Affolter, R.H., and Stricker, G.D., 1987, Variations in element distribution of coal from the Usibelli mine, Healy, Alaska, in Rao, P.D., ed., Focus on Alaska's Coal '86, conference proceedings: University of Alaska-Fairbanks, Mineral Industry Research Laboratory, MIRL Report 72, 396 p.

Alaska Department of Natural Resources, 1986, Oil and gas resources of Alaska: Alaska Division of Geological and Geophysical Surveys Information Circular 31, 9 p.

Alaska Journal of Commerce and Pacific Rim Reporter [published weekly by OCA Publishing Company, 16831 Tideview Drive, Suite B, Anchorage, AK 99516; formerly published by $\mathrm{Pa}$ cific Rim Publishing Company, 900 West 5th Avenue, Suite 410, Anchorage, AK 99501].

Alaska Miner [published monthly by Alaska Miners Association, 501 West Northern Lights Boulevard, Suite 203, Anchorage, AK 99503].

Alaska Oil and Gas Conservation Commission Bulletin [published monthly by the State of Alaska, Alaska Oil and Gas Conservation Commission, 3001 Porcupine Drive, Anchorage, AK 99501].

Alaska Report [published weekly by Petroleum Information Corporation, P.O. Box 102278, Anchorage, AK 99510].

Anchorage Daily News [published daily by Anchorage Daily News Incorporated, 1001 Northway Drive, Anchorage, AK 99501].

Anchorage Times [published daily by Anchorage Times Publishing Company, 820 West Fourth Avenue, Anchorage, AK 99501].

Armbrustmacher, T.J., 1989, Minor element content, including radioactive elements and rare-earth elements, in rocks from the syenite complex at Roy Creek, Mount Prindle area, Alaska: U.S. Geological Survey Open-File Report 89-146, 11 p.

Baggs, D.W., 1989, Bureau of Mines investigations in the Juneau mining district, 1984-1988 [abs.]: “Conference Juneau," Alaska Miners Association, April 19, 1989, Proceedings, p. 3.

Balen, M.D., 1989, Results of 1988 Bureau of Mines investigations in the Valdez Creek mining district, Alaska: U.S. Bureau of Mines Open-File Report 31-89, 136 p., 2 maps.

Berg, H.C., 1984, Regional geologic summary, metallogenesis, and mineral resources of southeastern Alaska: U.S. Geological Survey Open-File Report 84-572, 299 p., 1 sheet, scale $1: 600,000$. 
Bird, K.J., 1989, North American fossil fuels, in Bally, A.W., and Palmer, A.R., eds., The geology of North America-An overview: Boulder, Colorado, Geological Society of America (The Geology of North America, v. A), p. 555-573.

1990a, North Slope of Alaska, in Rice, D.D., ed., Economic geology-U.S., Oil and gas section, Regional synthesis of selected provinces: Boulder, Colorado, Geological Society of America (The Geology of North America series) [in press].

-1990b, Alaskan North Slope petroleum geology, geologic plays, and assessment results: U.S. Geological Survey OpenFile Report [in press].

Bohn, Diedra, ed., 1987, 1987 annual report on Alaska's mineral resources: U.S. Geological Survey Circular 1012, 59 p.

Bottge; R.G., 1989a, Availability of land for new mineral entry and development in Alaska, a summary report: U.S. Bureau of Mines Open-File Report 30-89, 24 p.

$1989 \mathrm{~b}$, Availability of land for mineral exploration and development in western Alaska, 1986: U.S. Bureau of Mines Special Publication 2-89, 48 p., 38 sheets, scale 1:500,000.

Bruns, T.R., 1988a, Petroleum potential of southeastern AlaskaA report for the National Hydrocarbon Assessment Program: U.S. Geological Survey Open-File Report 88-450-I, 7 p.

$-1988 \mathrm{~b}$, Petroleum geology and hydrocarbon plays of the Gulf of Alaska onshore province-A report for the National Hydrocarbon Assessment Program: U.S. Geological Survey Open-File Report 88-450-J, 30 p.

Bundtzen, T.K., Swainbank, R.C., Deagen, J.R., and Moore, J.L., 1990, Alaska's mineral industry, 1989: Alaska Division of Geological and Geophysical Surveys Special Report 44, 100 p.

Carlson, P.R., and Reimnitz, Erk, eds., 1990, Bottom sediment along oil spill trajectory in Prince William Sound and along Kenai Peninsula, Alaska: U.S. Geological Survey Open-File Report 90-39, 102 p.

Carter, L.M.H., ed., 1990, USGS research on energy resources, 1990 -Sixth annual V.E. McKelvey forum on mineral and energy resources, program and abstracts: U.S. Geological Survey Circular 1060, $99 \mathrm{p}$.

Clough, N.K., Patton, P.C., and Christiansen, A.C., eds., 1987, Arctic National Wildlife Refuge, Alaska, coastal plain resource assessment-Report and recommendation to the Congress of the United States and final legislative environmental impact statement: Washington, DC, Fish and Wildlife Service, U.S. Geological Survey, and Bureau of Land Management, 2 v., 208 p.

Cooke, L.W., 1985, Estimates of undiscovered, economically recoverable oil and gas resources for the Outer Continental Shelf as of July 1984: Minerals Management Service OCS Report, MMS 85-0012, 45 p.

Dolton, G.L., Carlson, K.H., Charpentier, R.R., Coury, A.B., Crovelli, R.A., Frezon, S.E., Khan, A.S., Lister, J.H., McMullin, R.H., Pike, R.S., Powers, R.B., Scott, E.W., and Varnes, K.L., 1981, Estimates of undiscovered recoverable conventional resources of oil and gas in the United States: U.S. Geological Survey Circular 860, 87 p.

Dover, J.H., and Galloway, J.P., eds., 1990, Geologic studies in Alaska by the U.S. Geological Survey, 1989: U.S. Geological Survey Bulletin 1946 [in press].

Fairbanks Daily News-Miner [published daily by the Fairbanks Publishing Company, 200 North Cushman, Fairbanks, AK
99701].

Fisher, M.A., 1988a, Petroleum geology of onshore part of Hope and Kotzebue basins, Alaska-A report for the Federal Lands Assessment Program (FLAP): U.S. Geological Survey OpenFile Report 88-383, 5 p.

-1988 b, Petroleum geology of rocks exposed on Kodiak Island, Alaska-A report for the Federal Lands Assessment Program (FLAP): U.S. Geological Survey Open-File Report 88-385, 6 p.

Foley, J.Y., Burns, L.E., Schneider, C.L., and Forbes, R.B., 1989, Preliminary report of platinum-group element occurrences in Alaska: Alaska Division of Geological and Geophysical Surveys Public-Data File 89-20, 32 p.

Geotimes [published monthly by the American Geological Institute, 4220 King Street, Alexandria, VA 22302-1507].

Green, C.B., and Bundtzen, T.K., 1989, Summary of Alaska's mineral industry in 1988: Alaska Division of Geological and Geophysical Surveys Public-Data File 89-7,6 p.

Harris, A.G., Lane, H.R., Tailleur, I.L., and Ellersieck, Inyo, 1987, Conodont thermal maturation patterns in Paleozoic and Triassic rocks, northern Alaska-Geologic and exploration implications, in Tailleur, Irv, and Weimer, Paul, eds., Alaska North Slope geology: Pacific section meeting, Society for Sedimentary Geology (SEPM), Bakersfield, Calif., June 1985, and Alaska Geological Society, v. 1, p. 181-191.

Hern, P.P., Jr., and Sher, Gerson, 1989, NSF, USGS, and Soviets sign agreements: Geotimes, v. 34, no. 7, p. 8-9.

Herzog, D.A., 1989, Heap leaching and its applicability to AlaskaInteragency Arctic Research Policy Committee: Arctic Research, v. 3, no. 1 , p. 64 .

Hoekzema, R., 1989a, Mineral future of Alaska: U.S. Bureau of Mines Mineral Issues, 1989, Competitiveness and Regulation, p. 22-36.

- 1989b, Alaska's National Petroleum Reservo-Explore it before locking the door: U.S. Bureau of Mines Minerals and Materials, April-May 1989, p. 7-14.

Juneau Empire [published daily by Morris Communications Incorporated, 3100 Channel Drive, Juneau, AK 99801].

Kirschner, C.E., 1988, Map showing sedimentary basins of onshore and continental shelf areas, Alaska: U.S. Geological Survey Miscellaneous Investigations Series Map I-1873, 1 sheet, scale $1: 2,500,000$.

Krason, J., and Finley, P., 1989, Basin analysis, formation, and stability of gas hydrates in the Beaufort Sea, v. 12 of Geological evolution and analysis of confirmed or suspected gas hydrate localities: Department of Energy/Morgantown Energy Technology Center, $227 \mathrm{p}$.

Leonard, K.R., and Huber, D.F., 1987, Status of Alaska Mineral Resources Data System, in Hamilton, T.D., and Galloway, J.P., eds., Geologic studies in Alaska by the U.S. Geological Survey during 1986: U.S. Geological Survey Circular 998, p. 15-18.

Magoon, L.B., 1990, The geology of known oil and gas resources by petroleum system-Onshore Alaska, in Plafker, G., Jones, D.L., and Berg, H.C., eds., Geology of Alaska: Boulder, Colorado, Geological Society of America (The Geology of North America series), [in press].

Magoon, L.B., and Kirschner, C.E., 1990, Alaska onshore national assessment program-Geology and petroleum resource potential of six onshore Alaska provinces: U.S. Geological Survey Open-File Report 88-450-T, 40 p. 
Mast, R.F., Dolton, G.L., Crovelli, R.A., Root, D.H., and Attanasi, E.D., U.S. Geological Survey; Martin, P.E., Cooke, L.W., Carpenter, G.B., Pecora, W.C., and Rose, M.B., Minerals Management Service; 1989, Estimates of undiscovered conventional oil and gas resources in the United States-A part of the Nation's energy endowment: U.S. Department of the Interior, $44 \mathrm{p}$.

McCammon, R.B., Light, T.D., and Rinehart, C.D., 1988, Mineral resource assessment, in Weber, F.R., McCammon, R.B., Rinehart, C.D., Light, T.D., and Wheeler, K.L., eds., Geology and mineral resources of the White Mountains National Recreation Area, east-central Alaska: U.S. Geological Survey Open-File Report 88-284, p. 95-119.

McLean, Hugh, 1987, Federal Lands Assessment Program-Alaska Peninsula, Alaska (province 68): U.S. Geological Survey Open-File Report 87-450-H, 7 p.

Mineral Alerts [published weekly by the U.S. Bureau of Mines, Washington, DC].

Minerals and Materials [published bimonthly by the U.S. Bureau of Mines, Washington, DC].

Minerals Yearbook [published annually by the U.S. Bureau of Mines, Washington, DC].

Moore, T.E., Wallace, W.K., Bird, K.J., Karl, S.M., Mull, C.G., and Dillon, J.T., 1990, Geology of northern Alaska, in Plafker, G., Jones, D.L., and Berg, H.C., eds., Geology of Alaska: Boulder, Colorado, Geological Society of America (The Geology of North America series), [in press].

Morgantown Energy Technology Center, 1987a, Gas hydrates technology status report: DOE/METC-87/0246 (NTIS/ DE87001027), 25 p.

-1987b, Deep-source gas technology status report: DOE/ METC-87/0250 (NTIS/DE87001031), 18 p.

1988, Arctic and offshore research technology status report: DOE/METC-88/0260 (NTIS/DE88001027), 44 p.

Mowatt, T.C., 1989a, Platinum and palladium in mafic-ultramafic igneous rocks, northwestern Alaska-Geochemical-petrological relationships, geological and mineral resource implications [abs.]: 28th International Geological Congress, Washington, DC, 1989, Abstracts, v. 2, p. 472.

1989b, Red dog mineral deposit, northwest Alaska-Discovery-delineation and government-private sector interaction [abs.]: 28th International Geological Congress, Washington, DC, 1989, Abstracts, v. 2, p. 472-473.

Nokleberg, W.J., Bundtzen, T.K., Berg, H.C., Brew, D.A., Grybeck, Donald, Robinson, M.S., Smith, T.E., and Yeend, Warren, 1987, Significant metalliferous lode deposits and placer districts of Alaska: U.S. Geological Survey Bulletin 1786, 104 p., 2 pl., scale 1:5,000,000.

Northem Miner [published weekly by Northem Miner Press Limited, 7 Labatt Avenue, Toronto, ON M5A 3P2, Canada].

O'Sullivan, P.B., 1988, Apatite fission-track study of the thermal history of Permian to Tertiary sedimentary rocks in the Arctic National Wildlife Refuge, northeastem Alaska: Alaska Division of Geological and Geophysical Surveys Public-Data File 88-42, 184 p.

1989a, Preliminary results of 24 fission-track analyses of samples from four wells in the National Petroleum Reserve in Alaska: Alaska Division of Geological and Geophysical Surveys Public-Data File 89-2A, 32 p.

1989b, Thermal history of Mississippian to Tertiary sedimentary rocks of the North Slope, Alaska, using apatite fission-track analysis: Alaska Division of Geological and Geophysical Surveys Public-Data File 89-2F, 130 p.

O'Sullivan, P.B., Decker, John, and Bergman, S.C., 1989, Apatite fission-track thermal history of Permian to Tertiary sedimentary rocks in the Arctic National Wildlife Refuge, northeastem Alaska [abs.]: Geological Society of America Abstracts with Programs, v. 21, no. 5, p. 126.

Roberts, S.B., Stricker, G.D., and Affolter, R.H., 1990, 200+ billion tons of low-sulfur coal in the Sagavanirktok Formation, North Slope, Alaska [abs.]: American Association of Petroleum Geologists, Rocky Mountain Section Meeting [in press].

Schindler, K.S., ed., 1988, USGS research on mineral resources, 1989 -Fifth annual V.E. McKelvey forum on mineral and energy resources, program and abstracts: U.S. Geological Survey Circular 1035, 98 p.

Schneider, J.L., ed., 1989, 1989 annual report on Alaska's mineral resources: U.S. Geological Survey Circular 1040, 70 p.

Shoemaker, H.D., and Chiang, D.L., 1988, The DOE Arctic and offshore research information system, in Brennan, A.M., and Andrews, M., eds., Glaciological Data Report GD-22: Twelfth Northern Libraries Colloquy, University of Colorado, Boulder, Colorado, June 5-9, 1988, p. 85-97.

Stanley, R.G., 1987, Thermal maturity and petroleum source potential of the Cantwell Formation (Paleocene), Alaska Range, in Hamilton, T.D., and Galloway, J.P., eds., Geologic studies in Alaska by the U.S. Geological Survey during 1986: U.S. Geological Survey Circular 998, p. 104-107.

1988, Hydrocarbon source potential and thermal maturity of the Sanctuary Formation (middle Miocene), northem foothills of the Alaska Range, in Galloway, J.P., and Hamilton, T.D., eds., Geologic studies in Alaska during 1987: U.S. Geological Survey Circular 1016, p. 117-120.

Stanley, R.G., Flores, R.M., and Wiley, T.J., 1989, Contrasting depositional environments in Tertiary fluvial deposits of Nenana coal field, Alaska [abs.]: American Association of Petroleum Geologists Bulletin, v. 73, no. 3, p. 415.

U.S. Bureau of Mines, 1989, Lode deposits, prospects, and occurrences of the Porcupine mining area, southeast Alaska: U.S. Bureau of Mines Open-File Report 17-89, 1 sheet.

Veith, D.L., Norland, M.R., and Helm, D.J., 1989, Utilization of mycorrhizae in the reclamation of cold climate mining wastes: First International Symposium on Mining in the Arctic, Fairbanks, Alaska, July 1989, Proceedings, p. 177-188.

Warner, J.D., and Barker, J.C., 1989, Columbium- and rare-earthelement-bearing deposits at Bokan Mountain, southeast Alaska: U.S. Bureau of Mines Open-File Report 33-89, 196 p.

Weber, F.R., Light, T.D., McCammon, R.B., and Rinehart, C.D., 1988, Mineral resource assessment of the White Mountains National Recreation Area, east-central Alaska [abs.], in Schindler, K.S., ed., 1988, USGS research on mineral resources, 1989-Fifth annual V.E. McKelvey forum on mineral and energy resources, program and abstracts: U.S. Geological Survey Circular 1035, p. 78. 


\section{APPENDIX 1. ALASKA MINERAL REPORTS RELEASED DURING 1989 AND EARLY 1990}

The following selected publications contain pertinent information about energy resources and other minerals in Alaska released during 1989 or early 1990; these are in addition to the reports listed in the previous References Cited section. This listing is only a selection of relevant reports from the publications of any agency. Reports by Federal or State agencies can generally be obtained from the agency offices in Alaska, or are available at the Alaska Resources Library, Federal Building, $701 \mathrm{C}$ Street, Anchorage, AK 99513-7599.

The USGS publishes a monthly listing of its own releases, "New Publications of the U.S. Geological Survey," available free from the U.S. Geological Survey, $582 \mathrm{Na}$ tional Center, Reston, VA 22092. These listings are also compiled into an annual volume, "Publications of the U.S. Geological Survey, 1989." Information about the prices and sources of listed reports is given in these two publications and is also available from the USGS Earth Science Information Centers.

The USBM's central distribution office is the Branch of Production and Distribution, 4800 Forbes Avenue, Pittsburgh, PA 15213. Many USBM reports are available from the U.S. Government Printing Office in Washington, DC, or from the National Technical Information Service (NTIS) in Springfield, VA 22161. USBM reports listed here are available from the USBM library in Juneau; for further information, contact the Chief, Alaska Field Operations Center, 201 East 9th Avenue, Anchorage, AK 99501.

MMS publications may also be purchased from NTIS, which issues listings of all available MMS volumes. A limited number of complimentary reports is available at the MMS Library/Public Information Room, Alaska OCS Region, Minerals Management Service, 949 East 36th Avenue, Room 110, Anchorage, AK 99508-4302; phone (907) 261-4439.

\section{Department of the Interior}

\section{U.S. Geological Survey}

Publications with one or more USGS authors:

Albers, J.P., and Fraticelli, L.A., U.S. Geological Survey, and Dawson, K.M., Geological Survey of Canada, 1989, Metallogenic maps of the northwest quadrant of the Circum-Pacific region, showing inferred mineral belts and distribution of oil and gas fields in accreted terranes and craton: U.S. Geological Survey Mineral Investigations Resources Map MR-95, 1 sheet, scale 1:20,000,000.

Barnes, D.F., Brew, D.A., and Morin, R.L., 1989, Bouguer gravity map of the Petersburg quadrangle and parts of the Port Alexander, Sitka, and Sumdum quadrangles, Alaska: U.S. Geological Survey Miscellaneous Field Studies Map MF-1970-A, 21 p., 1 sheet, scale 1:250,000.
Beyer, L.A., and Clutsom, F.G., 1989, Basic data and preliminary density and porosity profiles from three borehole gravity surveys made in the Kuparuk River and Prudhoe Bay oil fields, Alaska: U.S. Geological Survey Open-File Report 89-369, $26 \mathrm{p}$.

Bliss, J.D., 1989, Quantitative mineral resource assessment of undiscovered mineral deposits for selected mineral deposit types in the Chugach National Forest, Alaska: U.S. Geological Survey Open-File Report 89-345, 25 p.

Bohn, Diedra, ed., 1988, 1988 annual report on Alaska's mineral resources: U.S. Geological Survey Circular 1023, 57 p.

Brew, D.A., Grybeck, D.J., Cathrall, J.B., Karl, S.M., Koch, R.D., Barnes, D.F., Newberry, R.J., Griscom, Andrew, and Berg, H.C., 1989, Mineral-resource map of the Petersburg quadrangle and parts of the Port Alexander, Sitka, and Sumdum quadrangles, southeastern Alaska: U.S. Geological Survey Miscellaneous Field Studies Map MF-1970-B, 47 p., 1 sheet, scale 1:250,000.

Carter, L.D., Hamilton, T.D., and Galloway, J.P., eds., 1989, Late Cenozoic history of the interior basins of Alaska and the Yukon: U.S. Geological Survey Circular 1026, 114 p.

Cathrall, J.B., Antweiler, J.C., VanTrump, George, and Mosier, E.L., 1989, Gold, platinum, and silver analytical results and gold signatures from the Bonnifield mining district, Fairbanks and Healy quadrangles, Alaska: U.S. Geological Survey OpenFile Report 89-461, 23 p.

1989, Gold analytical results and gold signatures from the Fairbanks mining district, Fairbanks and Livengood quadrangles, Alaska: U.S. Geological Survey Open-File Report $89-490,32 \mathrm{p}$.

Cathrall, J.B., Albanese, Mary, VanTrump, George, Mosier, E.L., and Lueck, Larry, 1989, Geochemical signatures, analytical results, mineralogical data, and sample locality map of placer and lode gold and heavy-mineral concentrates from the Fortymile mining district, Eagle quadrangle, Alaska: U.S. Geological Survey Open-File Report 89-451, 32 p.

Church, S.E., 1988, Analytical data and sample locality map for aqua-regia leachates of stream sediments analyzed by ICP from the Port Moller, Stepovak Bay, and Simeonof Island quadrangles, Alaska: U.S. Geological Survey Open-File Report 88-437, 48 p., 1 sheet, scale 1:250,000.

Church, S.E., and Arbogast, B.F., 1989, Geochemical map showing the distribution of selected elements determined in nonmagnetic heavy-mineral concentrates from the Mount Katmai and portions of the Afognak and Naknek quadrangles, Alaska: U.S. Geological Survey Miscellaneous Field Studies Map MF2021-C, 1 sheet, scale 1:250,000.

Church, S.E., and Bennett, G.J., 1989, Mineralogical map showing the distribution of selected minerals identified in nonmagnetic heavy-mineral concentrates from the Mount Katmai and portions of the Afognak and Naknek quadrangles, Alaska: U.S. Geological Survey Miscellaneous Field Studies Map MF-2021-D, 1 sheet, scale 1:250,000.

Church, S.E., Bailey, E.A., and Riehle, J.R., 1989a, Geochemical map showing the distribution of selected elements determined in stream sediments from the Mount Katmai and portions of the Agofnak and Naknek quadrangles, Alaska: U.S. Geological Survey Miscellaneous Field Studies Map MF-2021-A, 1 sheet, scale 1:250,000.

Church, S.E., Detterman, R.L., and Wilson, F.H., 1989b, Mineral 
and energy resource assessment maps of the Ugashik, Bristol Bay, and western Karluk quadrangles, Alaska: U.S. Geological Survey Miscellaneous Field Studies Map MF-1539-I, 1 sheet, scale 1:250,000.

Church, S.E., Frisken, J.G., and Wilson, F.H., 1989c, Interpretation of exploration geochemical data from the Ugashik, Bristol Bay, and western Karluk quadrangles, Alaska Peninsula, Alaska: U.S. Geological Survey Bulletin 1858, 45 p.

Collett, T.S., Bird, K.J., Kvenvolden, K.A., and Magoon, L.B., 1989, Map showing the depth to the base of the deepest icebearing permafrost as determined from well logs, North Slope, Alaska: U.S. Geological Survey Oil and Gas Investigations Map OM-222, 1 sheet, scale 1:1,000,000.

Cox, Dennis, Light, T.D., Csejtey, Bela, Jr., and Campbell, D.L., 1989, Mineral resource assessment map of the Healy quadrangle, Alaska: U.S. Geological Survey Miscellaneous Field Studies Map MF-2058-A, 1 sheet, scale 1:250,000.

Crovelli, R.A., and Balay, R.H., 1989, TRIAGG: Triangular probability distribution aggregation for petroleum resource assessment: U.S. Geological Survey Open-File Report 89483, 29 p., 5.25" diskette.

Curtin, G.C., Tripp, R.B., and Nokleberg, W.J., 1989, Summary and interpretation of geochemical maps for stream sediment and heavy-mineral concentrate samples, Mount Hayes quadrangle, eastem Alaska Range, Alaska: U.S. Geological Survey Miscellaneous Field Studies Map MF-1996-B, 11 p., 3 sheets, scale 1:250,000.

Detterman, R.L., Case, J.E., Church, S.E., Frisken, J.G., Wilson, F.H., and Yount, M.E., 1989, The Alaska Mineral Resource Assessment Program: background information to accompany folio of geologic and resource maps of the Ugashik, Bristol Bay, and western Karluk quadrangles, Alaska: U.S. Geological Survey Circular 1046, 43 p.

Dickinson, K.A., and Pierson, C.T., 1988, A statistical analysis of chemical and mineralogic data from the Tertiary Kootznahoo Formation in southeastern Alaska, with emphasis on uranium and thorium: U.S. Geological Survey Bulletin 1851, 19 p.

Douglass, S.L., Webster, J.H., Burrell, P.D., Lanphere, M.A., and Brew, D.A., 1989, Major-element chemistry, radiometric ages, and locations of samples from the Petersburg and parts of the Port Alexander and Sumdum quadrangles, southeastern Alaska: U.S. Geological Survey Open-File Report 89-527, 66 p., 1 pl., scale 1:250,000.

Dover, J.H., and Galloway, J.P., eds., 1989, Geologic studies in Alaska by the U.S. Geological Survey, 1988: U.S. Geological Survey Bulletin 1903, 134 p.

DuBois, G.D., Wilson, F.H., Detterman, R.L., and Hopkins, R.T., 1989, Reconnaissance geology and exploration geochemistry of King Cove, Alaska Peninsula: U.S. Geological Survey Open-File Report 89-350, 23 p.

Erlich, Olga, Motooka, J.M., Church, S.E., Bailey, E.A., Arbogast, B.F., and Willson, W.R., 1988, Analytical data and sample locality map for aqua-regia leachates of stream sediments analyzed by ICP, and emission spectrographic results for both stream sediments and panned concentrates collected in 1985 from the Chandler Lake quadrangle, Alaska: U.S. Geological Survey Open-File Report 88-530, 38 p., 1 sheet, scale $1: 250,000$.

Fisher, M.A., Brocher, T.M., Nokleberg, W.J., Plafker, George, and Smith, G.L., 1989, Seismic reflection images of the crust of the northern part of the Chugach terrane, Alaska-Results of a survey for the Trans-Alaska Crustal Transect (TACT): Journal of Geophysical Research, v. 94, no. B4, p. 44244440.

Gamble, B.M., Bailey, E.A., and Reed, B.R., 1989, Gold occurrences near Snowcap Mountain, Lime Hills B-2 quadrangle, Alaska: U.S. Geological Survey Open-File Report 89-646, 9 p.

Goldfarb, R.J., Leach, D.L., Rose, S.C., and Landis, G.P., 1989a, Fluid inclusion geochemistry of gold-bearing quartz veins of the Juneau gold belt, southeastern Alaska-Implications for ore genesis, in Keays, R., Ramsay, R., and Groves, D., eds., The geology of gold deposits-The prospective in 1988: Economic Geology, Monograph 6 [in press].

Goldfarb, R.J., O'Leary, R.M., Sutley, S.J., and Tripp, R.B., 1989b, Geochemical survey of the Cordova and Middleton Island $1^{\circ}$ $\times 3^{\circ}$ quadrangles, southcentral Alaska: U.S. Geological Survey Bulletin 1865, 32 p., 3 pl.

Kaufman, D.S., Calkin, P.E., Whitford, W.B., Przybyl, B.J., Hopkins, D.M., Peck, B.J., and Nelson, R.E., 1989, Surficial geologic map of the Kigluaik Mountains area, Seward Peninsula, Alaska: U.S. Geological Survey Miscellaneous Field Studies Map MF-2074, 1 sheet, scale 1:63,360.

Kelley, J.S., 1989, Draft generalized geologic map of the Chandler Lake quadrangle, north-central Alaska: U.S. Geological Survey Open-File Report 89-495, 30 p., 1 sheet, scale 1:250,000.

Kelley, J.S., and Molenaar, C.M., 1989, Geologic map of the north flank of the Sadlerochit Mountains, Mount Michelson C-1, C-2, and C-3 quadrangles, northeastern Alaska: U.S. Geological Survey Open-File Report 89-11, 1 sheet, scale $1: 63,360$.

King, H.D., Light, T.D., and O'Leary, R.M., 1989a, Maps showing distribution and abundance of selected elements in streamsediment samples from a reconnaissance geochemical survey of the Healy quadrangle, Alaska: U.S. Geological Survey Miscellaneous Field Studies Map MF-2058-B, 2 sheets, scale $1: 250,000$.

King, H.D., Smith, S.C., and Werschky, Scott, 1989b, Mineralogical maps showing the distribution and abundance of selected minerals in nonmagnetic heavy-mineral-concentrate samples from stream-sediments, Solomon and Bendeleben $1^{\circ} \times 3^{\circ}$ quadrangles, Seward Peninsula, Alaska: U.S. Geological Survey Miscellaneous Field Studies Map MF-2071-C, 4 p., 1 sheet, scale 1:250,000.

King, H.D., Smith, S.C., Sutley, S.J., and Greene, K.R., 1989c, Geochemical maps showing the distribution and abundance of selected elements in nonmagnetic heavy-mineral-concentrate samples from stream-sediments, Solomon and Bendeleben $1^{\circ} \times 3^{\circ}$ quadrangles, Seward Peninsula, Alaska: U.S. Geological Survey Miscellaneous Field Studies Map MF. 2071-B, 13 p., 1 sheet, scale 1:250,000.

Koch, R.D., 1990, Reconnaissance geologic map of the Bradfield Canal quadrangle, southeastem Alaska: U. S. Geological Survey Miscellaneous Field Studies Map [in press].

Light, T.D., and Rinehart, C.D., 1989, Molybdenite in the Huron Creek pluton, western Livengood quadrangle, Alaska, in Dover, J.H., and Galloway, J.P., eds., Geologic studies in Alaska by the U.S. Geological Survey, 1988: U.S. Geological Survey Bulletin 1903, p. 54-61.

Light, T.D., King, H.D., and Sutley, S.J., 1989, Maps showing distribution and abundance of selected elements in heavy- 
mineral-concentrate samples from a reconnaissance geochemical survey of the Healy quadrangle, Alaska: U.S. Geological Survey Miscellaneous Field Studies Map MF-2058-C, 2 sheets, scale 1:250,000.

Luepke, Gretchen, and Escowitz, E.C., 1989, Grain-size, heavymineral, and geochemical analyses of sediments from the Chukchi Sea, Alaska: U.S. Geological Survey Bulletin 1896, $12 \mathrm{p}$.

Magoon, L.B., ed., 1989, The petroleum system-Status of research and methods, 1990: U.S. Geological Survey Bulletin 1912, $88 \mathrm{p}$.

Magoon, L.B., Bird, K.J., and Molenaar, C.M., 1989, Petroleum systems of the Arctic National Wildlife Refuge, northeastern Alaska-One of the remaining frontiers in U.S. petroleum exploration [abs.]: 28th International Geological Congress, Washington, DC, 1989, Abstracts, v. 2, p. 346.

McGimsey, R.G., Miller, M.L., and Arbogast, B.F., 1988, Analytical results and sample locality map for rock samples from the Iditarod quadrangle, Alaska: U.S. Geological Survey OpenFile Report 88-421, 13 p., 1 sheet, scale 1:250,000 [A-paper copy, B-5.25" diskettes].

Miller, M.L., Belkin, H.E., Blodgett, R.B., Bundtzen, T.K., Cady, J.W., Goldfarb, R.J., Gray, J.E., McGimsey, R.G., and Simpson, S.L., 1989, Pre-field study and mineral resource assessment of the Sleetmute quadrangle, southwestern Alaska: U.S. Geological Survey Open-File Report 89-363, 115 p., 3 sheets, scale 1:250,000.

Mosier, E.L., Cathrall, J.B., Antweiler, J.C., and Tripp, R.B., 1989, Geochemistry of placer gold, Koyukuk-Chandalar mining district, Alaska: Journal of Geochemical Exploration, v. 31, no. 3, p. 97-115.

Motooka, J.M., Smaglik, S.M., Church, S.E., and Bennett, G.J., 1988, Analytical data and sample locality map for aqua-regia leachates of stream sediments analyzed by ICP from the Bristol Bay, Ugashik, and westem Karluk quadrangles, Alaska: U.S. Geological Survey Open-File Report 88-435, 38 p., 1 sheet, scale 1:250,000.

Motooka, J.M., Adrian, B.M., Church, S.E., McDougal, C.M., and Fife, J.B., 1989, Analytical data and sample locality map for aqua-regia leachates of stream sediments analyzed by ICP, and emission spectrographic and ICP results for many NURE stream sediments from the Killik River quadrangle, Alaska: U.S. Geological Survey Open-File Report 89-12, 77 p., 2 sheets, scale 1:250,000.

Newberry, R.J., and Brew, D.A., 1989, Epigenetic hydrothermal origin of the Groundhog Basin-Glacier Basin silver-tin-leadzinc deposits, southeastem Alaska, in Dover, J.H., and Galloway, J.P., eds., Geologic studies in Alaska by the U.S. Geological Survey, 1988: U.S. Geological Survey Bulletin 1903, p. 113-121.

Newberry, R.J., Brew, D.A., and Levielle, R.A., 1989, Multiple sources of gold in the Juneau gold belt, Alaska [abs.]: "Conference Juneau," Alaska Miners Association, Juneau, Alaska, April 20-21, 1989, Abstracts with programs, p. 3-4.

Nokleberg, W.J., Plafker, George, Lull, J.S., Wallace, W.K., and Winkler, G.R., 1989, Structural analysis of the southern Peninsular, southern Wrangellia, and terranes along the TransAlaska Crustal Transect, northern Chugach Mountains: Joumal of Geophysical Research, v. 94, no. B4, p. 4297-4320.

Nokleberg, W.J., Bundtzen, T.K., Berg, H.C., Brew, D.A., Grybeck,
D.J., Robinson, M.S., and Smith, T.E., 1989, Metallogenic map of significant volcanogenic massive-sulfide and related lode deposits in Alaska: U.S. Geological Survey Miscellaneous Field Studies Map MF-1853-C, 1 sheet, scale 1:5,000,000.

Nokleberg, W.J., Lange, I.M., Singer, D.A., Curtin, G.C., Tripp, R.B., Campbell, D.L., and Yeend, Warren, 1990, Metalliferous mineral resource assessment maps of the Mount Hayes quadrangle, eastern Alaska Range, Alaska: U.S. Geological Survey Miscellaneous Field Studies Map MF-1996-A, 4 sheets, scale $1: 250,000$.

Page, R.A., 1989, Introduction to special section on the northern Chugach Mountains-Southem Copper River Basin of the Alaskan transect, Part 1: Journal of Geophysical Research, v. 94, no. B4, p. 4253-4254.

Patton, W.W., Jr., Box, S.E., Moll-Stalcup, E.J., and Miller, T.P., 1989, Geology of west-central Alaska: U.S. Geological Survey Open-File Report 89-554, 41 p., 10 figs.

Plafker, George, Nokleberg, W.J., and Lull, J.S., 1989, Bedrock geology and tectonic evolution of the Wrangellia, Peninsular, and Chugach terranes along the Trans-Alaska Crustal Transect in the Chugach Mountains and southern Copper River Basin, Alaska: Joumal of Geophysical Research, v. 94, no. B4, p. 4255-4295.

Plafker, George, Lull, J.S., Nokleberg, W.J., Pessel, G.H., Wallace, W.K., and Winkler, G.R., 1989, Geologic map of the Valdez A-4, B-3, B-4, C-3, C-4, and D-4 quadrangles, northern Chugach Mountains and southern Copper River Basin, Alaska: U.S. Geological Survey Open-File Report 89-569, 1 sheet, scale 1:125,000.

Richter, D.H., Ratte, J.C., Schmoll, H.R., Leeman, W.P., Smith, J.G., and Yehle, L.A., 1989, Geologic map of the Gulkana B1 quadrangle, south-central Alaska: U.S. Geological Survey Geologic Quadrangle Map GQ-1655, 1 sheet, scale 1:63,360.

Riehle, J.R., Bailey, E.A., Church, S.E., and Yount, M.E., 1989, Sample locality maps, analytical data, and statistical summary of analyses of rock samples from the Mount Katmai quadrangle and adjacent portions of the Naknek and Afognak quadrangles, Alaska: U.S. Geological Survey Open-File Report $89-570,136$ p., 2 sheets, scale 1:250,000.

Roberts, S.B., 1989, Cross section showing subsurface coal beds in the Sagavanirktok Formation, vicinity of Prudhoe Bay, North Slope, Alaska: U.S. Geological Survey Miscellaneous Investigations Map [in press].

Schmidt, R.A.M., Nokleberg, W.J., and Page, R.A., eds., 1989, Alaskan geological and geophysical transect, Valdez to Coldfoot, Alaska: 28th International Geological Congress, Washington, DC, 1989, Field Trip Guidebook T104, 131 p.

Schmitt, L.J., 1989, Map showing the distribution of oil shales with associated mineral resources and metal anomalies in the westem United States and Alaska: U.S. Geological Survey Miscellaneous Field Studies Map MF-2091, 2 sheets, scale $1: 2,500,000$.

Smith, S.C., King, H.D., and O'Leary, R.M., 1989, Geochemical maps showing the distribution and abundance of selected elements in stream-sediment samples, Solomon and Bendeleben $1^{\circ} \times 3^{\circ}$ quadrangles, Seward Peninsula, Alaska: U.S. Geological Survey Miscellaneous Field Studies Map MF-2071-A, 13 p., 1 sheet, scale 1:250,000.

Sutley, S.J., Goldfarb, R.J., O'Leary, R.M., and Tripp, R.B., 1989, Geochemical exploration within accretionary continental 
margins-An example from the Pacific Border Ranges, southern Alaska: Journal of Geochemical Exploration [in press].

Underwood, M.B., Laughland, M.M., Wiley, T.J., and Howell, D.G., 1989, Thermal maturity and organic geochemistry of the Kandik Basin region, eastcentral Alaska: U.S. Geological Survey Open-File Report 89-353, 41 p.

VanTrump, George, Jr., Motooka, J.M., Erlich, Olga, and Tompkins, M.L., 1988, Analytical data and sample locality map for aqua-regia leachates of stream sediments analyzed by ICP from the Chignik and Sutwik Island quadrangles, Alaska: U.S. Geological Survey Open-File Report 88-512, 40 p., 1 sheet, scale 1:250,000.

Weber, F.R., Wheeler, K.L., Dover, J.H., Rinehart, C.D., Blodgett, R.B., Cady, J.W., Karl, S.M., McCammon, R.B., and Miyaoka, R., 1988, Geologic framework, in Weber, F.R., McCammon, R.B., Rinehart, C.D., Light, T.D., and Wheeler, K.L., eds., Geology and mineral resources of the White Mountains National Recreation Area, east-central Alaska: U.S. Geological Survey Open-File Report 88-284, p. 4-58.

White, W.H., and Queen, L.D., 1989, Preliminary geologic and rock-chip geochemical data from drill core and trenches at the Shumagin gold deposit, Unga Island, Alaska: U.S. Geological Survey Open-File Report 89-361, 38 p.

Whitesides, Jonathan, and Schmidt, J.M., 1989, Map showing land status by section, western Brooks Range, Alaska: U.S. Geological Survey Open-File Report 89-316, 1 sheet, scale 1:500,000.

Wilson, F.H., White, W.H., and Detterman, R.L., 1988, Geology and mineral resources of the Port Moller region, western Alaska Peninsula, Aleutian Arc [abs.], in Schindler, K.S., ed., USGS research on mineral resources, 1989 -Fifth annual V.E. McKelvey forum on mineral and energy resources, program and abstracts: U.S. Geological Survey Circular 1035, p. $80-81$.

Woo, C.C., 1989, Mineralogical determination of heavy minerals in beach sands, Cape Mountain district, Seward Peninsula, Alaska: U.S. Geological Survey Open-File Report 89-155, 24 p., 6 tables.

\section{U.S. Bureau of Mines}

Barker, J.C., 1988, Distribution of platinum-group elements in an ultramafic complex near Rainbow Mountain, east-central Alaska Range, in Vassiliou, A.H., Hausen, D.M., and Carson, D.J.T., eds., Process Mineralogy VII: Applications to mineral beneficiation technology and mineral exploration with special emphasis on disseminated carbonaceous gold ores: Metallurgical Society Annual Meeting, Denver, Colorado, February 23-27, 1987, Symposium Proceedings, p. 197 220.

Barker, J.C., and Goff, K., 1989, Coal resources within the Yukon drainage, interior Alaska, in Rao, P.D., ed., Focus on Alaska's Coal '86, conference proceedings: University of Alaska-Fairbanks, Mineral Industry Research Lab, MIRL Report 72, p. 336-349.

Barker, J.C., and Mardock, C.L., 1988, Lithophile metal, REE-Y$\mathrm{Nb}$ deposits on southern Prince of Wales Island, Alaska, in Vassiliou, A.H., Hausen, D.M., and Carson, D.J.T., eds., Pro- cess Mineralogy VII: Applications to mineral beneficiation technology and mineral exploration with special emphasis on disseminated carbonaceous gold ores: Metallurgical Society Annual Meeting, Denver, Colorado, February 23-27, 1987, Symposium Proceedings, p. 139-157.

Barker, J.C., Robinson, M.S., and Bundtzen, T.K., 1989, Marine placer development and opportunities in Alaska, in 21st Annual Offshore Technology Conference, Houston, Texas, May 1989, Proceedings, v. 3, p. 551-558.

Blasko, D.P., 1989, Alaska's minerals-Precious, strategic and critical: Presented at Conference on Resources and Environment, National Cheng Kung University, Tainan, Taiwan, March 1989.

Burleigh, R.E., 1989, Tin and lead-silver mineralization in the Cosna River region, Alaska: U.S. Bureau of Mines Open-File Report 11-89, 19 p.

Carnes, R.D., 1989, Alaska mining reawakens: Alaska Economic Trends, November 1989, p. 1-4.

Foley, J.Y., 1989, History of the mineral industry in Alaska, and All that glitters is not gold: First International Symposium on Mining in the Arctic, Fairbanks, Alaska, July 1989, Proceedings, p. 9-13.

Foley, J.Y., Marcock, C.L., and Dahlin, D.C., 1988, Platinumgroup elements in the Tonsina ultramafic complex, southern Alaska, in Vassiliou, A.H., Hausen, D.M., and Carson, D.J.T., eds., Process Mineralogy VII: Applications to mineral beneficiation technology and mineral exploration with special emphasis on disseminated carbonaceous gold ores: Metallurgical Society Annual Meeting, Denver, Colorado, February 23-27, 1987, Symposium Proceedings, p. 165-195.

Greaves, J.N., McDonald, W.R., and Maysilles, J.H., 1989, Tungsten and gold recovery from Alaskan scheelite-bearing ores: U.S. Bureau of Mines Report of Investigations, RI-9251, 16p.

Jacobsen, Helen, 1989, Index of Bureau of Mines publications on Alaska: U.S. Bureau of Mines, 77 p.

Maas, K.M., 1989, Availability of land for mineral exploration and development in southwestem Alaska, 1986: U.S. Bureau of Mines Special Publication 1-89, 35 p.

O'Connor, W.K., Dahlin, D.C., and Warner, J.D., 1989, Characterization of the Sheep Creek $\mathrm{Pb}-\mathrm{Zn}$-Ag-Sn prospect, northcentral Alaska Range: U.S. Bureau of Mines Report of Investigations RI-9256, 15 p.

Skudrzyk, F.J., Barker, J.C., and Sugumaran, V., 1989, Disintegration of frozen granular materials using high-pressure water jets: Fifth International Cold Region Engineering Conference, St. Paul, Minnesota, February 1989, Proceedings, p. 320-334.

U.S. Bureau of Mines, 1989, U.S. Bureau of Mines Research '88A summary of significant results in mineral technology and economics: U.S. Bureau of Mines, $125 \mathrm{p}$.

Wamer, J.D., 1989, Columbium-, rare-earth-element-, and thoriumbearing veins near Salmon Bay, southeastern Alaska: U.S. Bureau of Mines Open-File Report 6-89, 25 p.

Wamer, J.D., and Dahlin, D.C., 1989, Tin occurrences associated with the Ohio Creek pluton, Chulitna region, southcentral Alaska: U.S. Bureau of Mines Open-File Report 5-89, 29 p.

White, B.A., Gunther, T.M., Johnson, R., and Adams, R.L., 1989, The potential supply of minerals from the White Mountains National Recreation Area and part of the North Steese National Conservation Area, Alaska: U.S. Bureau of Mines OpenFile Report 12-89, 355 p. 
Minerals Management Service

OCS Reports and Maps are authored by the MMS professional staff. OCS Studies are generally contractually prepared environmental, socioeconomic, and technological studies. Reports with one or more MMS authors:

Clarke, J., Moore, S., and Ljungblad, D., 1989, Observations on the gray whale (Eshrichtius robustus) utilization patterns in the northeast Chukchi Sea, July-October, 1982-1987: Canadian Journal of Zoology, v. 67, p. 2646-2653.

Cowles, C.J., 1989, Biological models as predictive tools for assessment of potential effects of Alaska Outer Continental Shelf oil and gas exploration, in Oceans '89, Seattle, Washington, September 18-21, 1989, Proceedings, v. 1, p. 307-310.

Dorsey, E., Richardson, J., and Wursig, B., 1989, Factors affecting surfacing, respiration and dive behavior of bowhead whales, Balaena mysticetus, summering in the Beaufort Sea: Canadian Journal of Zoology, v. 67, p. 1801-1815.

Fadely, B.S., Piatt, J.F., Hatch, S.A., and Roseneau, D.G., 1989, Populations, productivity, and feeding habits of seabirds at Cape Thompson, Alaska: Minerals Management Service OCS Study, MMS 89-0014, 429 p.

Fay, F.H., and Kelly, B.P., 1989, Development of a method for monitoring the productivity, survivorship, and recruitment of the Pacific walrus population: Minerals Management Service OCS Study, MMS 89-0012, 51 p.

French, D.P., and Reed, M., 1990, Potential impact of entanglement in marine debris on the population dynamics of the northen fur seal, Callorhinus ursinus: Second International Conference on Marine Debris, April 2-7, 1989, Proceedings [in press].

French, D.P., Reed, M., Calambokidis, J., and Cubbage, J., 1990, A simulation model of seasonal migration and daily movements of the northern fur seal, Callorhinus ursinus: Ecological Modeling [in press].

Hope, M.L., 1989, Archaeology on the Federal Outer Continental Shelf, in Coastal Zone '89, Sixth Symposium on Coastal and Ocean Management, Charleston, South Carolina, July 11-14, 1989, Proceedings, v. 4, p. 3526-3530.

-1989, Offshore archeology-The MMS in Alaska, in National Park Service, Federal archaeology report, August 1989, v. 2, p. 20.

Horowitz, W.L., Steffy, D.A., and Hoose, P.J., 1989, Geologic report for the Shumagin planning area, western Gulf of Alaska: Minerals Management Service OCS Report, MMS 89-0097, 150 p.

Impact Assessment Inc., 1989, Point Lay case study: Minerals Management Service OCS Study, MMS 89-0093, Technical Report No. 139.

-1989, Point Lay case study biographies: Minerals Management Service OCS Study, MMS 89-0094, Technical Report No. 140.

Institute of Social and Economic Research, University of AlaskaAnchorage, 1989, Economic and demographic systems analysis, Gulf of Alaska/Cook Inlet: Minerals Management Service OCS Study, MMS 89-0076, Technical Report No. 134.

Jarvela, L.E., and Thorsteinson, L.K., eds., 1989, Proceedings of the Gulf of Alaska, Cook Inlet, and North Aleutian Basin information update meeting, February 7-8, 1989, Anchorage,
Alaska: Minerals Management Service OCS Study, MMS 89-0041, 179 p.

Kevin Waring Associates, 1989, Regional and village corporation employment profiles: Minerals Management Service OCS Study, MMS 89-0084, Special Report No. 7.

1989, Demographic and employment analysis of selected Alaska rural communities: Minerals Management Service OCS Study, MMS 89-0083, Technical Report No. 137.

LGL Alaska Research Associates Inc., 1989, Synthesis of information on the effects of noise and disturbance on major haulout concentrations of Bering Sea pinnipeds: Minerals Management Service OCS Study, MMS 89-0092.

Malme, C.I., Miles, P.R., Miller, G.W., Richardson, W.J., Roseneau, D.G., Thomson, D.H., and Greene, C.R., 1989, Analysis and ranking of the acoustic disturbance potential of petroleum industry activities and other sources of noise in the environment of marine mammals in Alaska: Minerals Management Service OCS Study, MMS 89-0006, 293 p.

Mast, R.F., Dolton, G.L., Crovelli, R.A., Root, D.H., and Attanasi, E.D., U.S. Geological Survey; Martin, P.E., Cooke, L.W., Carpenter, G.B., Pecora, W.C., and Rose, M.B., Minerals Management Service; 1989, Estimates of undiscovered conventional oil and gas resources in the United States-A part of the Nation's energy endowment: U.S. Department of the Interior, $44 \mathrm{p}$.

Meyer, R.M., and Geiselman, J., 1990, Fisheries risk assessment in the Alaska OCS Region, in Petro Piscis, First International Conference on Fisheries and Offshore Petroleum Exploitation, Bergen, Norway, October 23-25, 1989, Proceedings, p. 533.

Minerals Management Service, 1989, Arctic area, Bering Sea, and Chukchi area oil and gas activities: Minerals Management Service OCS Map, MMS 89-0101, 3 sheets.

Mitchell, K.L., ed., 1989, Mercury in the marine environmentWorkshop proceedings: Minerals Management Service OCS Study, MMS 89-0049, 200 p.

Montague, J., 1990, The Soviet Far East opens the doors to marine mammal scientists [abs.]: Eighth Biennial Conference on the Biology of Marine Mammals, Pacific Grove, California, December 7-11, 1989 [in press].

Paul, R., coordinátor, 1989, Sale statistical and litigation summary, November 1989 update: Minerals Management Service, Alaska OCS Region, 182 p.

Reed, M., French, D.P., Calambokidis, J., and Cubbage, J., 1990, Simulation modeling of the effects of oil spills on population dynamics of northern fur seals: Ecological Modeling [in press].

Scherr, J., Banet, S., and Bascle, B., 1989, Correlation study of selected exploration wells from the North Slope and Beaufort Sea: Minerals Management Service OCS Report [in press].

Sherwood, K.W., 1990, Geological evolution of the northeastern Chukchi shelf [abs.]: Second Symposium on Studies Related to Continental Margins-A Summary of Year-Three and YearFour Activities, Austin, Texas, May 21-23, 1989, Program and Abstracts [in press].

Thorsteinson, L.K., Becker, P.R., and Hale, D.L., 1989, The Yukon Delta-A synthesis of information: Minerals Management Service OCS Study, MMS 89-0081, 89 p.

Thurston, D.K., 1989, Structural history of the Chukchi Sea planning area, Alaska [abs.]: American Association of Petroleum Geologists Bulletin, v. 73, no. 4, p. 553.

Treacy, S.D., 1989, Aerial surveys of endangered whales in the 
Beaufort Sea, fall 1988: Minerals Management Service OCS Study, MMS 89-0033, 101 p.

1990, Recent fall surveys of bowhead whales in the Alaskan Beaufort Sea [abs.]: Eighth Biennial Conference on the Biology of Marine Mammals, Pacific Grove, California, December 7-11, 1989 [in press].

Turner, R.F., Lynch, M.B., Hoose, P.J., Martin, G.C., Larson, J.A., Flett, T.O., Sherwood, K.W., and Adams, A.J., 1989, Gologic report for the North Aleutian Basin planning area, Bering Sea, Alaska: Minerals Management Service OCS Report [in press].

Turner, R.F., Larson, J.A., Olson, D.L., Flett, T.O., Lynch, M.B., Martin, G.C., Hoose, P.J., and Risely, D., 1989, Geologic report for the Gulf of Alaska planning area: Minerals Management Service OCS Report [in press].

Turner, R.F., Larson, J.A., Olson, D.L., Flett, T.O., Martin, G.C., Lynch, M.B., Comer, C.D. and Thurston, D.K., 1989, Geologic report for the Lower Cook Inlet planning area: Minerals Management Service OCS Report [in press].

U.S. Department of Commerce and U.S. Department of Interior, 1988, OCSEAP final reports of principal investigators, NOAA OCSEAP, v. 58: Minerals Management Service OCS Report, MMS 89-0002, 447 p.

-1988, OCSEAP final reports of principal investigators, NOAA OCSEAP, v. 59: Minerals Management Service OCS Report, MMS 89-0003, 465 p.

-1988, OCSEAP final reports of principal investigators, NOAAV OCSEAP, v. 61: Minerals Management Service OCS Report, MMS 89-0026, $536 \mathrm{p}$.

-1989, OCSEAP final reports of principal investigators, NOAA/ OCSEAP, v. 60: Minerals Management Service OCS Report, MMS 89-0004, 563 p.

1989, OCSEAP final reports of principal investigators, NOAA/ OCSEAP, v. 62: Minerals Management Service OCS Report, MMS 89-0063, $635 \mathrm{p}$.

-1989, OCSEAP final reports of principal investigators, NOAA/ OCSEAP, v. 63: Minerals Management Service OCS Report, MMS 89-0071, 594 p.

-1989, OCSEAP final reports of principal investigators, NOAA/ OCSEAP, v. 64: Minerals Management Service OCS Report, MMS 89-0088, $448 \mathrm{p}$.

Wursig, B., 1989, Cetaceans: Science, v. 244, p. 1550-1557.

Wursig, B., Dorsey, E., Richardson, J., and Wells, R., 1989, Feeding, aerial and play behavior of the bowhead whale, Balaena mysticetus, summering in the Beaufort Sea: Aquatic Mammals, v. 15 , no. 1 , p. $27-37$.

\section{Bureau of Land Management}

Banet, A.C., Jr., 1990, Petroleum geology and geochemistry of the Arctic National Wildlife Refuge 1002 area: U.S. Bureau of Land Management Alaska Technical Report 12.

U.S. Bureau of Land Management, Alaska State Office, 1988, Beaver Creek placer mining final cumulative environmental impact statement: U.S. Department of the Interior.

1988, Birch Creek placer mining final cumulative environmental impact statement: U.S. Department of the Interior.

1988, Fortymile River placer mining final cumulative environmental impact statement: U.S. Department of the Interior.
1989. Beaver Creek placer mining Record of Decision:

U.S. Department of the Interior.

1989, Birch Creek placer mining Record of Decision: U.S. Department of the Interior.

1989, Fortymile River placer mining Record of Decision:

U.S. Department of the Interior.

-1989, Minto Flats placer mining final cumulative environmental impact statement: U.S. Department of the Interior.

1989, Minto Flats placer mining Record of Decision: U.S. Department of the Interior.

1989, Placer mining in Alaska, a guide to mitigation and reclamation: U.S. Department of the Interior.

\section{Fish and Wildlife Service}

U.S. Fish and Wildlife Service, Bureau of Land Management, National Park Service, U.S. Department of Agriculture Forest Service, 1989, Alaska Submerged Lands Act report-Analysis of inholdings, acquisition priorities, and recommendations to reduce impacts on conservation system units in Alaska, draft: U.S. Department of Interior, Anchorage, Alaska.

\section{National Park Service}

U.S. National Park Service, 1989, Aniakchak National Monument and Preserve, Alaska - Final environmental impact statement and wilderness recommendation: Alaska Regional Office, 232 p.

1989, Mining in Denali National Park and Preserve, AlaskaDraft environmental impact statement: Alaska Regional Office, $391 \mathrm{p}$.

1989, Wrangell-St. Elias National Park and Preserve, AlaskaDraft environmental impact statement and cumulative impacts of mining: Alaska Regional Office, 523 p., 5 pl. 1989, Yukon-Charley Rivers National Preserve, Alaska - Draft environmental impact statement and cumulative impacts of mining: Alaska Regional Office, 369 p., 2 sheets.

\section{Department of Energy}

List includes publications resulting from DOEsponsored research:

Jeffries, M.O., and Sackinger, W.M., 1989, Analysis and interpretation of an airborne synthetic aperture radar image of Hobson's Ice Island, in Axelsson, K.B.E., and Fransson, L.A., eds., Tenth International Symposium on Port and Ocean Engineering Under Arctic Conditions, Luleł̊, Sweden, June 1989, v. 2, p. 1032-1041.

-1989, Some measurements and observations of very old sea ice and brackish ice, Ward Hunt Ice Shelf, N.W.T.: Journal of Atmosphere-Ocean, v. 27, p. 553-564.

1989, Airborne SAR characteristics of arctic ice shelves and multiyear landfast sea ice, and the detection of massive ice calvings and ice islands: International Geoscience and Remote Sensing Symposium (IGARSS '89), 12th Canadian Symposium on Remote Sensing, Vancouver, British Colum- 
bia, 1989, Proceedings, v. 4, p 2715-2718.

1990, Ice island detection and characterization with airborne SAR: Journal of Geophysical Research, v. 95, no. C4, p. 5371-5377.

Jeffries, M.O., Krouse, H.R., Sackinger, W.M., and Serson, H.V., 1989 , Stable isotope $\left({ }^{18} \mathrm{O} /{ }^{16} \mathrm{O}\right)$ tracing of fresh, brackish, and sea ice in multiyear landfast sea ice, Ellesmere Island, Canada: Journal of Glaciology, v. 35, p. 9-16.

-1990, Surface topography, ice thickness and ice core studies of multiyear landfast sea ice and Ward Hunt Ice Shelf, northern Ellesmere Island, N.W.T., in Harington, C.R., ed., The Canadian Arctic Islands-Canada's Missing Dimension, Syllogeus, National Museum of Natural Sciences, Ottawa, Ontario, p. 229-254.

Li Fu-cheng, Sackinger, W.M., Jeffries, M.O., and Lu Ming-chi, 1989, Computer simulation of the probabilities of ice island trajectories in the Arctic Ocean, in Axelsson, K.B.E., and Fransson, L.A., eds., Tenth International Symposium on Port and Ocean Engineering Under Arctic Conditions, Luleå, Sweden, June 1989, v. 2, p. 1063-1072.

Lu Ming-chi, and Sackinger, W.M., 1989, The mountain barrier effect and modification of tabular iceberg motion in a coastal ice zone: Journal of Coastal Research, v. 5, p 701-710.

Sackinger, W.M., and Jeffries, M.O., 1989, Recent ice island creation events, drift laws and recurrence intervals, mechanical properties, and interactions with offshore oil production structures, in Komar, C.A., Malone, R.D., and Byrer, C.W., eds., Natural Gas Research and Development Contractors Review Meeting, U.S. Department of Energy, Morgantown Energy Technology Center, Morgantown, West Virginia, Proceedings, p. 419-431.

Sackinger, W.M., and Li Fu-cheng, 1989, Permanent artificial islands and structures in ice-infested coastal locations: Journal of Ocean Engineering (China), No. 4 (in Chinese).

Sackinger, W.M., Jeffries, M.O., Tippens, H., Li Fu-cheng, and Lu Ming-chi, 1989, Dynamics of ice island motion near the coast of Axel Heiberg Island, Canadian High Arctic: Annals of Glaciology, v. 12, p. 152-156.

Sellman, P.V., Delaney, A.J., and Arcone, S.A., 1989, Coastal subsea permafrost and bedrock observations using DC resistivity: U.S. Army Corps of Engineers, Cold Regions Research and Engineering Laboratory, CRREL Report 89-13, 13 p.

Sellman, P.V., Reimnitz, E., and Kempema, E.W., 1989, Sea floor temperature and conductivity data from coastal waters of the U.S. Beaufort Sea: U.S. Army Corps of Engineers, Cold Regions Research and Engineering Laboratory, CRREL Report $89-1,19$ p.

\section{Non-Federal Reports}

\section{Alaska Division of Geological and Geophysical Surveys}

List includes publications by the ADGGS and other publications with ADGGS authors:

Anderson, A.V., 1989, Relationship between stratigraphy and structural geometry southwest of Bathtub Ridge, northeastern Brooks Range, Alaska (ANWR)_Preliminary results: Alaska Division of Geological and Geophysical Surveys Public-Data
File 89-1d, 24 p., 1 sheet, scale 1:25,000.

Brewer, W.M., and Craddock, C., 1989, Geologic map of the Mount Deborah area, central Alaska Range, Alaska: Alaska Division of Geological and Geophysical Surveys Report of Investigations 89-1, 4 sheets, scale 1:63,360.

Bujak Davies Group, 1989, Palynological analysis of 48 outcrop samples from the Colville River and Ivishak River areas, northern Alaska (ANWR): Alaska Division of Geological and Geophysical Surveys Public-Data File 89-26c, 48 p.

Bundtzen, T.K., 1988, A history of mining in the Kantishna Hills: Alaska Geographic, v. 15, no. 3, p. 51-61.

Bundtzen, T.K., ed., 1989, Placer mining in today's world: Eleventh Annual Conference on Placer Mining, Fairbanks, Alaska, 1989, Proceedings, 83 p.

Bundtzen, T.K., and Laird, G.M., 1989, Geology and mineral resources of the Russian Mission C-1 quadrangle, Alaska: Alaska Division of Geological and Geophysical Surveys Public-Data File 89-17, 31 p., 2 sheets, scale 1:63,360.

Bundtzen, T.K., Laird, G.M., and Gilbert, W.G., 1989, Material studies along Kuskokwim River, McGrath to Kalskag, southwest Alaska: Alaska Division of Geological and Geophysical Surveys Public-Data File 89-16, 84 p.

Clough, J.G., General stratigraphy of the Katakturuk dolomite in the Sadlerochit and Shublik Mountains, Arctic National Wildlife Refuge, northeastem Alaska: Alaska Division of Geological and Geophysical Surveys Public-Data File 89-4a, 11 p., 1 sheet, scale 1:25,000.

Decker, John, Robinson, M.S., Clough, J.G., and Lyle, W.M., 1989, Geology and petroleum potential of Hope and Selawik Basins, offshore northwestern Alaska: Marine Geology, v. 90, no. $1 / 2$, p. $1-18$.

Foley, J.Y., Burns, L.E., Schneider, C.L., and Forbes, R.B., 1989, Preliminary report of platinum-group-element occurrences in Alaska: Alaska Division of Geological and Geophysical Surveys Public-Data File 89-20, 33 p., 1 sheet, scale 1:2,500,000.

Green, C.B., Bundtzen, T.K., Peterson, R.J., Seward, A.F., Deagen, J.R., and Burton, J.E., 1989, Alaska's mineral industry, 1988: Alaska Division of Geological and Geophysical Surveys Special Report 43, 79 p.

Hanks, C.L., 1989, Preliminary geology of the pre-Mississippian rocks of the Aichilik and Egaksrak River areas, northeastem Brooks Range, Alaska (ANWR): Alaska Division of Geological and Geophysical Surveys Public-Data File 89-1a, 32 p., 1 sheet, scale 1:25,000.

Hanks, C.L., and Wallace, W.K., 1989, Preliminary geologic map of the northern margin of the Okpilak batholith between McCall Creek and the Okpilak River, northeastern Brooks Range, Alaska (ANWR): Alaska Division of Geological and Geophysical Surveys Public-Data File 89-1f, 15 p., 1 sheet, scale 1:25,000.

Motyka, R.J., Queen, L.D., Janik, C.J., Sheppard, D.S., Poreda, R.J., and Liss, S.A., 1988, Fluid geochemistry and fluid-mineral equilibria in test wells and thermal gradient holes at the Makushin geothermal area, Unalaska Island, Alaska: Alaska Division of Geological and Geophysical Surveys Report of Investigations 88-14, $90 \mathrm{p}$.

Mull, C.G., and Adams, K.E., eds., 1989, Dalton Highway, Yukon River to Prudhoe Bay, Alaska: Alaska Division of Geological and Geophysical Surveys Guidebook 7, 2 vols., 2 plates.

Myers, M.D., 1989, Petrography of upper Cretaceous and lower 
Tertiary sandstones, Beaufort-MacKenzie basin: Alaska Division of Geological and Geophysical Surveys Public-Data File 89-27, 16 p., 1 sheet.

Newberry, R.J., and Burns, L.E., 1989, Probabilistic estimation of gold resources in the Circle-Fairbanks-Kantishna area: Alaska Division of Geological and Geophysical Surveys Public-Data File 89-9, 34 p.

O'Sullivan, P.B., 1989, Preliminary results of 14 apatite fissiontrack analyses of samples from the Umiat and Colville River region, North Slope, Alaska (ANWR): Alaska Division of Geological and Geophysical Surveys Public-Data File 89-1e, 22 p.

-1989, Preliminary results of nine apatite fission-track analyses of samples from the Slope Mountain and Sagavanirktok River region, North Slope, Alaska: Alaska Division of Geological and Geophysical Surveys Public-Data File 89-2c, 15 p.

-1989, Preliminary results of five apatite fission-track analyses of samples from the Jago River Formation exposed in the Arctic National Wildlife Refuge, North Slope, Alaska: Alaska Division of Geological and Geophysical Surveys Public-Data File 89-2d, 10 p.

Ray, S.R., 1989, Hydrologic and water-quality investigations related to placer mining in interior Alaska, summer 1988: Alaska Division of Geological and Geophysical Surveys Public-Data File 89-23, 25 p.

Reger, R.D., and Bundtzen, T.K., 1990, Multiple glaciation and gold placer formation, Valdez Creek valley, western Clearwater Mountains, Alaska: Alaska Division of Geological and Geophysical Surveys Professional Report 107, 1 sheet, scale 1:63,360.

Reifenstuhl, R.R., 1989, Measured stratigraphic section of the 'Gilead Creek Sandstone,' northeastern Alaska (ANWR): Alaska Division of Geological and Geophysical Surveys Public-Data File 89-26b, 16 p., 1 sheet, scale 1:720.

Robinson, M.S., 1989, Kerogen microscopy of coal and shales from the North Slope of Alaska: Alaska Division of Geological and Geophysical Surveys Public-Data File 89-22, 19 p.

Robinson, M.S., Imm, T.A., and Clough, J.G., 1989, Measured stratigraphic section of volcanic rocks in the Lisburne Group, Ivishak River area, ANWR: Alaska Division of Geological and Geophysical Surveys Public-Data File 89-26a, 4 p.

Robinson, M.S., Decker, John, Clough, J.G., Reifenstuhl, R.R., Dillon, J.T., Combellick, R.A., and Rawlinson, S.E., 1989, Geology of the Sadlerochit and Shublik Mountains, Arctic National Wildlife Refuge, northeastem Alaska: Alaska Division of Geological and Geophysical Surveys Professional Report 100, 1 sheet, scale 1:63,360.

Rogers, J.A., 1989, Structural evolution of the central Shublik Mountains and Ignek Valley, northeastern Brooks Range, Alaska (ANWR): Alaska Division of Geological and Geophysical Surveys Public-Data File 89-1c, 37 p.

Smith, T.E., Pessel, G.H., Clautice, K.H., and Solie, D.N., 1989, Geology and mineral occurrences, upper Clearwater Creek area, Mount Hayes A-6 quadrangle, Alaska: Alaska Division of Geological and Geophysical Surveys Public-Data File 8918,14 p., 2 sheets, scale 1:24,000.

Watts, Keith, 1989, Carboniferous Lisburne group of the Arctic National Wildlife Refuge, Brooks Range, northeastern Alaska-Progress report summarizing initial results of 1988 research: Alaska Division of Geological and Geophysical
Surveys Public-Data File 89-1g, 34 p.

Wiltse, M.A., and Reger, R.D., 1989, Geologic map of Gold Hill and Lucky Hill, Valdez Creek mining district, Healy A-1 quadrangle, Alaska: Alaska Division of Geological and Geophysical Surveys Public-Data File 89-5, 1 sheet, scale $1: 12,000$.

Wiltse, M.A., Clautice, K.H., and Sturmann, A.G., 1989, Preliminary comments regarding a soil-geochemistry orientation survey, Gold Hill, Valdez Creek mining district, Healy A-1 quadrangle, Alaska: Alaska Division of Geological and Geophysical Surveys Public-Data File 89-11, 10 p.

\section{Additional Non-Federal Publications}

Abrams, M.A., 1989, Geophysical and geochmemical evidence for subsurface hydrocarbon leakage in southern Bering sea, Alaska [abs.]: American Association of Petroleum Geologists Bulletin, v. 73, no. 3, p. 325.

Alaska Association of Petroleum Landmen, and Alaska Support Industry Alliance, 1989, Alaska oil and gas directory: Anchorage, Alaska, Alaska Support Industry Alliance.

Bally, A.W., ed., 1989, Atlas of seismic stratigraphy: American Association of Petroleum Geologists, Studies in Geology, no. 27,3 vols.

Belfield, W.C., 1989, Characterization of naturally fractured carbonate reservoir, Lisburne field, Prudhoe Bay, Alaska [abs.]: American Association of Petroleum Geologists Bulletin, v. 73, no. 3, p. 333.

Bronston, M.A., 1990, Offshore placer drilling technology-A case study from Nome, Alaska: Mining Engineering, v. 42, no. 1, p. 26-31.

California Mining Journal, 1989, New gold and silver found in Alaska by U.S.Bureau of Mines: California Mining Journal, v. 58, no. 7, p. 10.

Cao, S., and Lerche, I., 1989, Geohistory, thermal history, and hydrocarbon generation history of Navarin Basin COST No. 1 well, Bering Sea, Alaska: Journal of Petroleum Geology, v. 12 , no. 3., p. 325-352.

Dunn, C.E., and Scagel, R.K., 1989, Tree-top sampling from a helicopter-A new approach to gold exploration: Journal of Geochemical Exploration, v. 34, no. 3, p. 255-270.

Finley, P.D., 1989, Geothermal gradient estimates for continental margin north of Alaska [abs.]: American Association of Petroleum Geologists Bulletin, v. 73, no. 3, p. 355.

Giegerich, H.M., 1989, Introduction to the Red Dog project: Canadian Mining and Metallurgical Bulletin, v. 82, no. 925, p. 31-33.

Hargrave, W.R., 1989, The Red Dog mine: Canadian Mining and Metallurgical Bulletin, v. 82, no. 925, p. 34-36.

Hough, Harold, 1989, Bima dredge works the Bering Sea: California Mining Journal, v. 58, no. 12, p. 5-7.

International Oil Scouts Association, 1989, International oil and gas development yearbook (review of 1986), v. 57, Exploration: Austin, Texas, Mason Map Service [Alaska, p. 134-135]. 1989, International oil and gas development yearbook (review of 1987), v. 58, Exploration: Austin, Texas, Mason Map Service [Alaska, p. 159].

-1990, Intemational oil and gas development yearbook (review of 1988), part 2, Production: Austin, Texas, Mason Map Service [Alaska, p. 110]. 
Jameson, Jeremy, 1989, Interactions between early and late diagenesis in reservoir formation, Lisburne field, Prudhoe Bay, Alaska [abs.]: American Association of Petroleum Geologists Bulletin, v. 73, no. 3, p. 367-368.

Krutak, P.R., 1989, Lisburne Group (Mississippian-Lower Permian) petrography, paragenesis, and hydrocarbon potential, central Brooks Range, Alaska [abs.]: American Association of Petroleum Geologists Bulletin, v. 73, no. 3, p. 375.

Lu, Changseng, 1989, Mineralogy and geochemistry of the skam formation at Tin Creek, Alaska [abs.]: 28th International Geological Congress, Washington, DC, 1989, Abstracts, v. 2, p. 333.

Madonna, J.A., ed., 1988, Alaskan placer mining: Tenth Annual Conference on Placer Mining, Fairbanks, Alaska, 1988, Proceedings, $87 \mathrm{p}$.

Metz, P.A., Freeman, C.J., Adams, D.D., and Balla, J.C., 1989, Late Proterozoic precious-metal-bearing sequences in interior Alaska [abs.]: Geological Society of America Abstracts with Programs, v. 21, no. 5, p. 116-117.

Munger, A.H., ed., 1989, Munger map book, Califormia-Alaska oil and gas fields, 33rd edition: Los Angeles, Munger, p. AL1AL8.

Oil and Gas Journal, 1989, ARCO-Exxon-BP to delineate Prudhoe area oil discovery: Oil and Gas Journal, v. 87, no. 9, p. 46.

-1989, ANWR issue off and running again: Oil and Gas Journal, v. 87 , no. 12 , p. $35-38$.

-1989, Shell outlines first Chukchi Sea wildcat program: Oil and Gas Journal, v. 87, no. 13, p. 26-29.

-1989, Alaska tax increase shelves West Sak project: Oil and Gas Journal, v. 87, no. 26, p. 28.

1989, Alaska proposes addition of three 1994 lease sales: Oil and Gas Joumal, v. 87, no. 44, p. 28.

-1989, ARCO spuds well off ANWR's coast with Glomar CIDS: Oil and Gas Journal, v. 87, no. 44, p. 27.

Petroleum Information, 1989, Resume 1987: The complete annual review of oil and gas activity in the United States: Petroleum Information Corporation [Alaska, p. 139-151].

Rintoul, Bill, 1989, Alaska-In the wake of the Valdez spill: Pacific Oil World, v. 81, no. 8, p. 4-9.

-1989, Alaska drilling/production: Pacific Oil World, v. 82, no. 1, p. $56-60$.

Skillings' Mining Review, 1989, U.S. nonfuel minerals industries experience substantial improvement in 1988: Skillings' Mining Review, v. 78, no. 15 [Alaska, p. 9-10].

Smosna, Richard, 1989, Compaction law for Cretaceous sandstones of Alaska's North Slope: Journal of Sedimentary Petrology, v. 59, no, 4, p. 572-584.

Steenblock, L.J., and Blubaugh, Colynn, 1989, Oil and gas developments in Alaska in 1988: American Association of Petroleum Geologists Bulletin, v. 73, no. 10, Pt. B, p. 36-40.

Sweeney, M.D., and Naidu, A.S., 1988, Heavy metals in sediments of the inner shelf of the Beaufort Sea, northern arctic Alaska: Marine Pollution Bulletin, v. 20, no. 3, p. 140-143.

Taylor, E.F., 1989, Early exploration for hydrocarbons in the North American Arctic [abs.]: American Association of Petroleum Geologists Bulletin, v. 73, no. 9, p. 1144-1145.

Turner, B.R., and Whateley, M.K.G., 1989, Tidally influenced coal-bearing sediments in the Tertiary Bering River coalfield, south-central Alaska: Sedimentary Geology, v. 61, no. 1-2, p. 111-123.
Watkins, D.H., and Melling, D.R., 1989, Genesis of Pd-Pt-Au-Ag$\mathrm{Hg}$ minerals in $\mathrm{Cu}$-rich sulfides-Salt Chuck mafic-ultramafic rock complex, Alaska [abs.]: Geological Association of Canada and Mineralogical Association of Canada, Annual Meeting, Montreal, 1989, Program with Abstracts, v. 14, p. A48.

Williams, Bob, 1989, Alaska tax hikes cloud latest giant's prospects: Oil and Gas Joumal, v. 87, no. 33, p. 26.

\section{APPENDIX 2. ROLES OF FEDERAL AGENCIES IN MINERAL PROGRAMS}

\section{Department of the Interior}

\section{U.S. Geological Survey}

The mission of the USGS is to develop and interpret the geologic, topographic, and hydrologic data necessary for prudent management of the Nation's minerals, land, and water. The USGS carries out its mission through research that produces geographic, cartographic, and remotely sensed information; geologic, geochemical, and geophysical maps and studies; energy, mineral, and water resource assessments; geohazards research, including toxic waste studies; and participation in multidisciplinary projects, maintaining data bases, and publishing reports and maps.

In Alaska, the USGS is active in assessing minerals, including metalliferous and energy resources. Field and laboratory researchers also gather information about domestic petroleum, coal, uranium, and geothermal resources. At the request of land-managing agencies, the USGS provides mineral resource assessments for land planning, including wilderness studies. Within Alaska, the USGS maintains offices for its Geologic, National Mapping, and Water Resources Divisions. Within the Geologic Division, the Branch of Alaskan Geology is the primary USGS office studying mineral resources in Alaska; the Branch is headquartered in Anchorage with a field office in Fairbanks. Other Alaska Branch geologists are stationed in Menlo Park, California. During the summer field season, many USGS scientists from other branches within the Geologic Division conduct mineral-related research in Alaska.

\section{U.S. Bureau of Mines}

The mission of the USBM is to help ensure that the Nation's mineral supplies are adequate to maintain national security, economic growth, and employment. The USBM's Alaska Technology Transfer Office (ATTO), located in Anchorage, is responsible for working with other Federal agencies, the State, universities, and industry on technology issues and needs; conducting technology transfer briefings; and facilitating work with USBM research centers throughout the United States. The USBM's Alaska Field Operations Center (AFOC) has headquarters in Anchorage and 
offices in Juneau and Fairbanks. The AFOC carries out its mission through five programs:

1. Minerals availability program.-This program is part of a worldwide USBM program responsible for developing the Minerals Availability System (MAS) computer data base and the Mineral Industry Location System (MILS), a subset of MAS. MILS contains basic information about the identification and location of known mineral deposits. MAS is more extensive, containing information about reserve estimates, mineral extraction and beneficiation methodologies, environmental constraints to mining, and cost analyses for selected major mineral deposits. A computer and communication system allow the information to be stored, manipulated, and retrieved as computer-plotted map overlays and printouts of MAS/MILS data, enabling rapid and uniform development of cost data for MAS mineral-deposit evaluations. MAS and MILS mineral-deposit data are cross-indexed to several other mineralsinformation data bases.

2. Policy analysis.-This program emphasizes analyses of newly developed and existing mineral data to interpret their significance relative to local and national mineral needs. Assessment of technical, institutional, political, social, and economic factors that affect the supply of, and demand for, domestic and international minerals is the key to identifying mineral issues.

3. State mineral activities.-This program covers minerals-related activities in Alaska and assists in developing and releasing nonfuel-mineral-industry information. The section of State Mineral Activities in Alaska provides USBM direct communication with the ADGGS, the Alaska Division of Mining, other minerals-oriented government agencies, industry, private firms, and individuals. The USBM's State Mineral Officer collects, analyzes, and reports mineral data and develops information regarding activities and trends in the mining industry. This program produces the annual USBM Mineral Yearbook chapters and Mineral Industry Surveys.

4. Mineral land assessment.-This is the USBM's major Alaskan program, conducted in cooperation with other Federal and State agencies. Mineral assessments are both areal and commodity-oriented. In support of the Secretary of the Interior's commitment to assess the mineral potential of public lands in Alaska, the AFOC initiated a program in 1985 to evaluate mineral resources of the mining districts in the State. The program seeks to identify the type, amount, and distribution of mineral deposits; related studies will determine economic feasibility. Legislative effects on mineral development will also be addressed. The USBM has completed the study of the Juneau mining district; studies of the Ketchikan and Valdez Creek mining districts have been initiated.

A statewide program provides an inventory and specific technical evaluations of Alaska's strategic and critical mineral deposits on Federal lands that are closed to mineral entry and on lands that are open to entry but not of current interest to industry. In addition to locating, mapping, and estimating the size and grade of deposits, the USBM obtains bulk samples for metallurgic research to determine recovery and extraction methods and costs. These studies are undertaken in cooperation with the USBM Research Centers in Albany, Oregon, and Salt Lake City, Utah. These investigations provide reserve estimates of marginal and submarginal deposits in Alaska and its coastal waters.

5. Minerals research.-The USBM is attempting to provide solutions to mining, mineral recovery, and environmental problems in Alaska through a number of research efforts and technology transfer. Several research projects are currently being conducted in Alaska by USBM research centers or at universities sponsored by the USBM's Mineral Institute Program. USBM and university research centers cooperate with AFOC to solve mineral utilization problems.

\section{Minerals Management Service}

The MMS was created in 1982 with a twofold mission: (1) to administer leasing, exploration, development, and production of mineral resources, including oil and gas, on the Outer Continental Shelf (OCS), and (2) to collect and disburse revenues generated from mineral leases on Federal and Indian lands. The MMS is also responsible for oil rig safety, oil rig pollution control regulations, determination of environmental impact of resource development, and estimation of oil and gas resources. At present, revenues from the Alaska OCS are primarily derived from competitive leasing activities; no development or production occurs there at this time. The MMS also has the authority to lease OCS lands for ocean mining of hard minerals. The responsibility of the MMS for onshore Alaskan minerals is limited to the collection of royalties and rents from Federal and certain Native lands. The MMS also holds occasional Synthesis Meetings and Informational Transfer Meetings, Regional Technical Working Group Meetings, Coordination Team Meetings, Environmental Impact Study Hearings, and scoping meetings relating to specific planning areas or subject areas. The public is invited to attend these meetings and can contact the MMS Regional Office for specific subjects, dates, and times.

In Alaska, the MMS is active in assessing the oil and gas potential of offshore basins through the analysis of geophysical and geologic data. This work is integrated into the National Resource Assessment and is a basis for evaluations of the potential monetary worth of individual OCS lease blocks, for appraisals of the resource potential of entire basins, and for the creation of geologic models for basin development. The MMS also conducts specialized studies of deep stratigraphic test (DST) wells and exploratory wells drilled on OCS lands. All of this work is carried out at the MMS Regional Office in Anchorage, Alaska. The results of these studies are published through the MMS OCS Report 
series or in appropriate outside journals. The MMS also sponsors resource-oriented geologic studies through the Program for Studies Related to Continental Margins, which funds research by State agencies and affiliated academic institutions.

\section{Bureau of Land Management}

The BLM manages Federal onshore mineral resources. The BLM also works cooperatively with the NPS, FWS, and USFS to provide technical evaluation of the mineral-related issues on lands under these agencies' jurisdiction.

Multiple-use resource management decisions concerning all minerals on the 92 million acres of land currently managed by the BLM in Alaska (fig. 1) are made through the Resource Management Planning process. The BLM first identifies the mineral potential of each planning unit. The effects of mineral exploration, development, and production, and land abandonment and rehabilitation are then analyzed for the concerns and sensitivities of the other resources present. Mitigation measures are developed and evaluated to reduce or avoid adverse impacts of the anticipated mineral activities. Field monitoring of all phases of mineral activity ensures that no unnecessary or undue degradation occurs. The BLM also provides resource management for retained Federal mineral estates on an additional 100 million acres.

\section{Fish and Wildlife Service}

The FWS provides Federal leadership to conserve, protect, and enhance fish and wildlife and their habitats for the continuing benefit of people. In Alaska, the FWS seeks to accomplish this mission through programs that implement provisions of the Endangered Species Act, Marine Mammal Protection Act, Fish and Wildlife Coordination Act, Rivers and Harbors Act, National Wildlife Refuge System Administration Act, Alaska National Interest Lands Conservation Act (ANILCA), various migratory-bird laws and treaties, and other statutes.

Under ANILCA, 16 refuges in Alaska (fig. 4) were created or enlarged to conserve fish and wildlife populations and their habitats, as well as other values. Except for valid rights existing at the time of establishment, these refuges are closed to entry and location under mining laws. The refuges are open to entry under leasing laws but are closed to the mining of coal by the Federal Coal Leasing Amendments Act of 1975 and closed to geothermalresource leasing by the Geothermal Steam Act of 1970 . Although many traditional activities have been deemed appropriate for these refuges, other uses, including oil and gas leasing, will be permitted only when such activities are compatible with the purposes for which the refuges were established.

\section{National Park Service}

In 1916, Congress established the NPS and stated that the fundamental purpose of the nation's parks, monuments, and other reservations was "to conserve the scenery and natural and historical objects and the wildlife therein and to provide for enjoyment of the same in such a manner and by such means as will leave them unimpaired for the enjoyment of future generations" (39 Stat. 535). NPS management policies are based on the concept of conservation and preservation while providing for appropriate enjoyment of natural and cultural resources within the park system. Congress enacted the "Mining in the Parks Act" in 1976, declaring that a continued application of the mining laws of the United States to park units conflicts with the purposes for which they were established and that all mining operations in park units "should be conducted so as to prevent or minimize damage to the environment and the other resource values" (90 Stat. 1342). The NPS manages mining activities through regulations found at Title 36, Part 9, Subpart A of the Code of Federal Regulations. These regulations apply to mining-related activities on patented or valid unpatented claims located under the Mining Law of 1872. Proposed plans of operations for these claims must conform to the regulations.

Under the broad authorities granted the Secretary of the Interior by Congress (39 Stat. 535) for regulation of activities to protect park resources, the NPS has promulgated regulations at Title 36, part 9, Subpart B of the Code of Federal Regulations that control all activities in any unit of the National Park System in the exercise of rights to nonfederally owned oil and gas. A regulation (36 CFR 13.15(d)(2)) that rendered 36 CFR 9B inapplicable to Alaska has been deleted in the action which established DOI's new access regulations for Conservation System Units. Thus, the NPS's non-Federal oil and gas regulations now apply in National Park System units in Alaska. Plans of operation are now required of operators who, within park units, must access their nonfederally owned oil and gas on, across, or through federally owned or controlled lands or waters.

\section{Department of Agriculture}

\section{U.S. Forest Service}

The mission of the USFS is to provide a continuing flow of natural-resource goods, including mineral and energy resources, to help meet national needs and contribute to meeting such needs worldwide. It is the responsibility of the USFS to encourage and support environmentally sound mineral enterprises on Federal lands under its administration. In managing the use of these resources, the Forest Service's objective is to minimize unnecessary adverse environmental impacts to surface and cultural features and values which might result from lawful exploration and de- 
velopment operations. This objective is accomplished through the application of reasonable conditions that do not interfere with well-planned mineral operations. The Forest Service also provides research information and technology to help with post-mining reclamation. In implementing this policy, the Chief of the USFS directed that:

1. A key objective of the minerals program is to encourage and facilitate the orderly exploration, development, and production of mineral resources.

2. Minerals, like range, recreation, timber, water, wildlife, and wilderness, are one of the multiple uses the Forest Service manages.

3. Forest Service managers must develop a good understanding of the minerals industry, its practices, and the minerals laws and regulations.

4. Managers must develop a strong working relationship with the minerals industry.

5. Visibility and interaction with the minerals industry must be increased by attendance and participation of line officers and appropriate staff at industry and professional association activities and meetings.

6. Directories, organization charts, and receptionists direct the mineral industry to personnel who have mineralsadministration responsibilities.

\section{Department of Energy}

The DOE's mission is to reduce the Nation's vulnerability to disruptions of energy supplies and to mitigate any adverse impacts on the Nation should a shortage occur.
With regard to Alaska, the energy sources currently being addressed by the DOE are fossil fuels (petroleum and coal) and geothermal.

The strategy for responding to petroleum-supply interruptions is to rely on the free market, supplemented as necessary and appropriate with other measures, such as the Strategic Petroleum Reserve. The DOE's Fossil Energy Research and Development Programs are aimed at careful consideration of the alternatives available and the relative chances for success in fostering an adequate supply of energy at a reasonable cost through long-term, high-risk research and development. Alternatives for increasing domestic petroleum supplies include (1) DOE's Unconventional Gas Recovery Program, which emphasizes the development of advanced technologies for the extraction of natural gas from resources that are classified as unconventional because of unique geologic settings and production mechanisms that are not now well understood, and (2) DOE programs for developing tertiary oil recovery, tar sands, and heavy-oil deposits of the United States.

The purpose of the DOE's Geothermal Energy Program is to develop the technology needed by industry for the use of geothermal resources. DOE research is aimed toward improving methods used to locate, extract, and convert geothermal heat to usable forms of energy. Through DOE funding in Alaska, Federal and State agencies have researched and published several studies of specific geothermal systems.

A further purpose of DOE programs is to generate data essential to the private sector's decisionmaking process, leading to the development of commercial projects. 

เ 


\section{SELECTED SERIES OF U.S. GEOLOGICAL SURVEY PUBLICATIONS}

\section{Perlodicals}

Earthquakes \& Volcanoes (issued bimonthly). Preliminary Determination of Epicenters (issued monthly).

\section{Technical Books and Reports}

Professional Papers are mainly comprehensive scientific reports of wide and lasting interest and importance to professional scientists and engineers. Included are reports on the results of resource studies and of topographic, hydrologic, and geologic investigations. They also include collections of related papers addressing different aspects of a single scientific topic.

Bulletins contain significant data and interpretations that are of lasting scientific interest but are generally more limited in scope or geographic coverage than Professional Papers. They include the results of resource studies and of geologic and topographic investigations; as well as collections of short papers related to a specific topic.

Water-Supply Papers are comprehensive reports that present significant interpretive results of hydrologic investigations of wide interest to professional geologists, hydrologists, and engineers. The series covers investigations in all phases of hydrology, including hydrogeology, availability of water, quality of water, and use of water.

Circulars present administrative information or important scientific information of wide popular interest in a format designed for distribution at no cost to the public. Information is usually of short-term interest.

Water-Resources Investigations Reports are papers of an interpretive nature made available to the public outside the formal USGS publications series. Copies are reproduced on request unlike formal USGS publications, and they are also available for public inspection at depositories indicated in USGS catalogs.

Open-File Reports include unpublished manuscript reports, maps, and other material that are made available for public consultation at depositories. They are a nonpermanent form of publication that may be cited in other publications as sources of information.

\section{Maps}

Geologic Quadrangle Maps are multicolor geologic maps on topographic bases in 7 1/2- or 15 -minute quadrangle formats (scales mainly $1: 24,000$ or $1: 62,500$ ) showing bedrock, surficial, or engineering geology. Maps generally include brief texts; some maps include structure and columnar sections only.

Geophysical Investigations Maps are on topographic or planimetric bases at various scales; they show results of surveys using geophysical techniques, such as gravity, magnetic, seismic, or radioactivity, which reflect subsurface structures that are of economic or geologic significance. Many maps include correlations with the geology.

Miscellaneous Investigations Series Maps are on planimetric or topographic bases of regular and irregular areas at various scales; they present a wide variety of format and subject matter. The series also includes 7 1/2-minute quadrangle photogeologic maps on planimetric bases which show geology as interpreted from aerial photographs. Series also includes maps of Mars and the Moon.
Coal Investigations Maps are geologic maps on topographic or planimetric bases at various scales showing bedrock or surficial geology, stratigraphy, and structural relations in certain coal-resource areas.

Oil and Gas Investigations Charts show stratigraphic information for certain oil and gas fields and other areas having petroleum potential.

Miscellaneous Field Studies Maps are multicolor or black-andwhite maps on topographic or planimetric bases on quadrangle or irregular areas at various scales. Pre-1971 maps show bedrock geology in relation to specific mining or mineral-deposit problems; post-1971 maps are primarily black-and-white maps on various subjects such as environmental studies or wilderness mineral investigations.

Hydrologic Investigations Atlases are multicolored or black-andwhite maps on topographic or planimetric bases presenting a wide range of geohydrologic data of both regular and irregular areas; principal scale is 1:24,000 and regional studies are at 1:250,000 scale or smaller.

\section{Catalogs}

Permanent catalogs, as well as some others, giving comprehensive listings of U.S. Geological Survey publications are available under the conditions indicated below from the U.S. Geological Survey, Books and Open-File Reports Section, Federal Center, Box 25425, Denver, CO 80225. (See latest Price and Availability List.)

"Publications of the Geological Survey, 1879-1961" may be purchased by mail and over the counter in paperback book form and as a set of microfiche.

"Publications of the Geological Survey, 1962-1970" may be purchased by mail and over the counter in paperback book form and as a set of microfiche.

"Publications of the U.S. Geological Survey, 1971- 1981" may be purchased by mail and over the counter in paperback book form (two volumes, publications listing and index) and as a set of microfiche.

Supplements for 1982, 1983, 1984, 1985, 1986, and for subsequent years since the last permanent catalog may be purchased by mail and over the counter in paperback book form.

State catalogs, "List of U.S. Geological Survey Geologic and Water-Supply Reports and Maps For (State)," may be purchased by mail and over the counter in paperback booklet form only.

"Price and Availability List of U.S. Geological Survey Publications," issued annually, is available free of charge in paperback booklet form only.

Selected copies of a monthly catalog "New Publications of the U.S. Geological Survey" available free of charge by mail or may be obtained over the counter in paperback booklet form only. Those wishing a free subscription to the monthly catalog "New Publications of the U.S. Geological Survey" should write to the U.S. Geological Survey, 582 National Center, Reston, VA 22092.

Note.--Prices of Government publications listed in older catalogs, announcements, and publications may be incorrect. Therefore, the prices charged may differ from the prices in catalogs, announcements, and publications. 
